Portland State University

PDXScholar

\title{
A History of Transportation in Nineteenth Century Umatilla County, Oregon
}

Gary Kenneth Miller

Portland State University

Follow this and additional works at: https://pdxscholar.library.pdx.edu/open_access_etds

Part of the History Commons

Let us know how access to this document benefits you.

Recommended Citation

Miller, Gary Kenneth, "A History of Transportation in Nineteenth Century Umatilla County, Oregon" (1996). Dissertations and Theses. Paper 5159.

https://doi.org/10.15760/etd.7035

This Thesis is brought to you for free and open access. It has been accepted for inclusion in Dissertations and Theses by an authorized administrator of PDXScholar. Please contact us if we can make this document more accessible: pdxscholar@pdx.edu. 


\section{THESIS APPROVAL}

The abstract and thesis of Gary Kenneth Miller for the Master of Arts in History were presented April 26, 1996, and accepted by the thesis committee and the department.

COMMITTEE APPROVALS:

Gordon B. Dodds, Chair

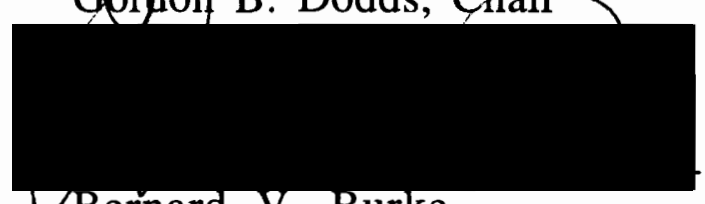

VBernard V. Burke

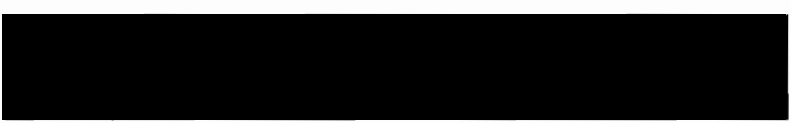

Friedrich Schuler

DEPARTMENT APPROVAL:

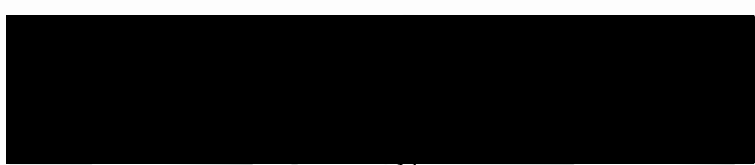

Candice L. Goucher

Representative of the Office of Graduate Studies

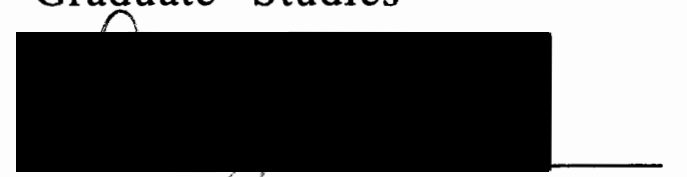

David ACJohnson, Chair

Department of History

ACCEPTED FOR PORTLAND STATE UNIVERSITY BY THE LIBRARY

By on

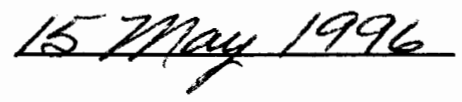


AN ABSTRACT OF THE THESIS OF Gary Kenneth Miller for the Master of Arts in History presented April 26, 1996.

Title: A History of Transportation in Nineteenth Century Umatilla County, Oregon.

An examination of the history of transportation in Umatilla County, Oregon, will provide an understanding of its role in the colonization and economic development of this remote and arid region. This study begins with a description of the movement of Umatilla, Walla Walla, and Cayuse Indians in the Umatilla Country to establish the patterns of transportation at the beginning of the nineteenth century. From this basis, significant changes in transportation technology and patterns of movement can be identified and analyzed.

Primary sources are reviewed to establish existing routes and conditions of travel. Immigrant accounts and pioneer reminiscences reveal that difficulties with transportation were identified very early as the major obstacle to the development of an agriculture-based market economy. Umatilla County archives provide a clear record of the actions taken by the county government to lay out and maintain wagon roads. 
Three significant changes are identified in nineteenth century transportation in Umatilla County: introduction of the horse, introduction of wheeled vehicles, and the coming of steampowered vessels and trains. Each of these three developments were revolutionary, adding to the capacity and range of the existing transportation system.

The sudden demands for transportation as a result of gold strikes east and south of Umatilla County created the need to expand the regional transportation system. That expanded system was then available to new settlers. As the dominant land use was transformed from livestock grazing to dryland wheat farming, the need for railroads, in addition to Columbia River steamboats, became clearly evident. Feeder roads remained very important, as did animal traction to pull the wagons to the warehouses and loading docks along the rail lines. The location of major routes of travel across the Umatilla Indian Reservation resulted in significant problems for the transportation system. The system to establish and maintain county roads, mandated by state law, involved direct participation of individuals residing adjacent to the roads.

Throughout the nineteenth century, the patterns of movement remained remarkably unchanged. Based on ancient Indian trails, the transportation system was the crucial element in the economic development of Umatilla County. 


\title{
A HISTORY OF TRANSPORTATION IN NINETEENTH CENTURY \\ UMATILLA COUNTY, OREGON
}

\author{
b y \\ GARY KENNETH MILLER
}

A thesis submitted in partial fulfillment of the requirements for the degree of

\author{
MASTER OF ARTS \\ in \\ HISTORY
}

Portland State University

1996 


\section{ACKNOWLEDGEMENTS}

Several individuals have given generous assistance and encouragement toward the completion of this thesis. I have had the good fortune to have as my academic advisor Professor Gordon B. Dodds. In Umatilla County, the help and hospitality of the following individuals made my research visits fruitful and enjoyable: Thomas E. Bailor, Cultural Resources Technician, Confederated Tribes of the Umatilla Indian Reservation; Julie Alford, Cartographer, Planning Department, Umatilla County; and Jeanne Gorham of the Roadmaster's Office, Umatilla County. Finally, Donald McManman of West Richland, Washington, provided unstinting logistical support and encouragement. I am pleased to offer my thanks. 


\section{THE HISTORY OF TRANSPORTATION \\ IN NINETEENTH CENTURY \\ UMATILLA COUNTY, OREGON}

\section{TABLE OF CONTENTS}

Chapter

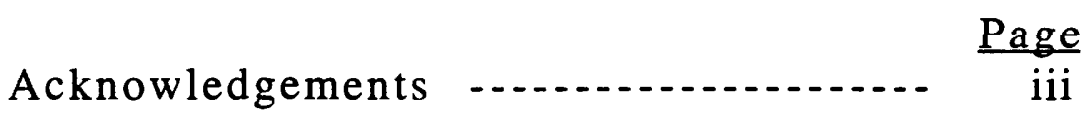

Introduction

1

Native American Transportation -.......- 6

Movement of Explorers, Trappers, and

Traders

Missionaries' Impact

The Mining Frontier

48

6

Stagecoach and Express Travel

Movement of Livestock

Establishment of Governmental, Social, and Commercial Institutions ..... 108

9 Farm-to-Market Transportation and the Impact of Railroads ........ 145

Appendices

A

County Court of Umatilla County

Preamble and Resolution in the

Matter of Roads ................ 173 
Appendices

$\underline{\text { Page }}$

B In the Matter of Establishing a County

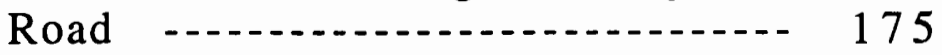

C Report, Survey \& Plat of Co. Road

from Umatilla City via McKay

Cr. to Blue Mts. on Meacham

Road

D Maps

Map 1, Umatilla County in

Oregon -........... 180

Map 2, Roads over the Blue

Mountains

181

Map 3, Roads in Western

Umatilla County .................. 183

Map 4, Railroads in Umatilla

County

185

Map 5, Walla Walla-Wallula

Railroads

186

Bibliography

188 


\section{CHAPTER 1}

\section{INTRODUCTION}

From ancient to modern times, transportation has been critical to sustainable human habitation in the Great Columbia Plain of the Pacific Northwest. Routes and patterns of travel have developed in clear stages within this distinctive geographical area that resembles a rough triangle with the apex in the north at the mouth of the Okanogan River, and the southern line running from the Deschutes area of Oregon tilting upward to the Camas Prairie of northern Idaho. 1 The scarcity of both population and natural resources focuses attention on human activities in the region.

The Columbia River was, and remains, the great highway of the Northwest. The river and its tributaries provided life-giving water to an arid land. It furnished salmon and a medium of transportation for inhabitants: one a staple food and cultural necessity, the other a means of trade and movement. People moved in purposeful patterns along its tributaries and on overland trails expanding outward from the Columbia.

1 D. W. Meinig, The Great Columbia Plain, A Historical Geography, 1805 1910, (Seattle: University of Washington Press, 1968), 4. This rich work is a primary source for information regarding the patterns of human movement studied in this thesis. 
Umatilla County provides a useful subject for the study of the history of transportation in the inland area of the Pacific Northwest (see Appendix D, Map 1). It was one of the last areas of the continental United States to be settled. Because its settlement was so recent, archival records and personal remembrances are numerous. Umatilla County is bordered on the northwest and heavily influenced by the Columbia River. Just across the state line in Washington the Whitman Mission at Waiilatpu and later the city of Walla Walla exerted influence as centers of commerce and transportation. Various branches of the Oregon Trail and other pioneer roads penetrated the Blue Mountains to the east and south, a formidable but permeable natural obstacle to travel. Umatilla Landing, and later Pendleton, served as centers of communications in a growing agricultural region.

Umatilla County did not come into being as a distinct political entity until 1862, when it was split off from Wasco County. For purposes of this study, Umatilla County is essentially synonymous with Umatilla Country, the term used when referring to pre-1862 history. Also, while the Whitman Mission and Walla Walla are across the arbitrarily drawn state line, a transportation history of Umatilla County could not be written without reference to their significant influence.

Various early explorers and trappers, Robert Stuart of the Hudson's Bay Company and Colonel John C. Frémont, for example, 
were famed as "pathmakers" or "trailblazers."2 It is not meant to denigrate the courage or accomplishments of these men to say that to follow a path is not to make one. Archer B. Hulbert, writing in 1920 of Indian trails declared: "To a larger degree than has ever been realized, the explorers, conquerors, and settlers of any portion of this country were indebted to the narrow trail of the Indian" and "Today the main lines of travel and transportation for the most part still cling to these primeval pathways." 3 The Venango Trail became an early colonial military road, and is now the route of the highway between Erie and Watertown, Pennsylvania. Daniel Boone won fame for opening the Wilderness Road to Kentucky; but he followed the ancient "Warriors' Path," a link in the famous "War Trail of Nations." Again, Hulbert: "There is no trunk railway across the Appalachian system today [1902] which is not in general alignment with one of these prehistoric thoroughfares." 4 Transportation historian Christy Borth wrote:

In the United States, especially, many modern highways follow military roads which were laid out along wilderness trails trodden by trappers and traders and their pack-animals; and, as old records show, such bold adventurers merely followed the footpaths of Indians in

2 For example, Allan Nevins wrote Frémont: Pathmaker of the West, (1939), a reissue of his earlier work titled Frémont: the West's Greatest Adventurer.

3 Archer B. Hulbert, The Paths of Inland Commerce, A Chronicle of Trail, Road, and Waterway, (New Haven: Yale University Press, 1920), 14.

4 Archer B. Hulbert, Indian Thoroughfares, Vol. 2 of "Historic Highways of America," (New York: AMS Press, 1971), 13, 66, 91-92, 144, 149. 
pursuit of animals moving from water-hole to salt-lick to pasture to forest cover. 5

The Umatilla Country, no different from the nation, was crisscrossed by a network of well-established Indian trails that provided the way for trappers, traders, missionaries, immigrants, miners, soldiers, and settlers. Many of the major and minor roads studied in this thesis will be shown to follow those ancient routes.

At first, however, the Umatilla Country was not a destination for white men. Westward bound pioneers of the 1840s and 1850s bypassed the arid Columbia Plain in favor of the lush Willamette Valley. The gold finds of the 1860s in Idaho, Montana and Eastern Oregon caused another surge of traffic through the region, this one eastward. The mining operations offered entrepreneurs and settlers along the trade routes a chance to look anew at the region. Livestock ranchers and then dryland wheat farmers found opportunity as Umatilla County finally became a destination.

Throughout this development, transportation was the crucial ingredient in economic success. From paddled canoes to steam navigation on the Columbia, from narrow trails to transcontinental rail connections, Umatilla County witnessed people on the move, economically ambitious, challenging the capacities of existing systems of transportation until new capabilities were developed. This study ends with the close of the nineteenth century, or to be

5 Christy Borth, Mankind on the Move, The Story of Highways, (Washington, D. C.: Automotive Safety Foundation, 1969), 11-12. 
more specific, with the advent of the internal combustion engine. The use of animal transportation and traction on roadways are its focus as railroads and steam navigation on the Columbia have been investigated by other scholars. The impact of those systems of transportation on road development, however, is crucial to this study.

This study will attempt to answer several questions regarding the history of transportation in Umatilla County. What were the conditions found by the earliest white men to visit the region? What significant changes in transportation occurred with the advent of white men and women? To what extent was the development of transportation tied to the economic development of Umatilla County? What were the relationships between agricultural development and changes in patterns of transportation?

Secondary and primary sources are used to describe the patterns of trade and transportation of Native Americans, fur traders and explorers. Primary sources from county archives, newspapers, and personal remembrances are used to detail the history of transportation from the time that Umatilla County was created. The focus will be on the development of roads and road connections. 


\section{CHAPTER 2}

\section{NATIVE AMERICAN TRANSPORTATION}

Before the Europeans arrived, the indigenous peoples of the Columbia Plain lived in stability and isolation. Their one plentiful natural resource, salmon coming in prodigious runs, bound them at least seasonally to the river banks. In the Umatilla Country there were three distinct tribes: the Walla Walla, the Umatilla, and the Cayuse, sharing the same Plateau culture and Sahaptin language stock. Other tribes, such as the Nez Perce, Tenino, and Shoshone, ebbed and flowed sporadically on the margins, but their movements were limited to traditional hunter-gatherer ranges. ${ }^{6}$

Then came the horses. Early in the eighteenth century, these animals entered the region through Shoshonean tribes along the Snake River Plain. ${ }^{7}$ The impact on the Indians of the Umatilla Country, particularly the Cayuse, was immense. Historian D. W. Meinig described this influence:

This new mobility improved hunting efficiency, enlarged the economic area, extended trading contacts, and intensified warfare with traditional enemies to the south

6 Verne F. Ray, et al., Tribal Distribution in Eastern Oregon and Adjacent Regions, American Anthropologist, n.s., Vol. 40 (July-September, 1938), 391-405; Verne F. Ray, Native Villages and Groupings of the Columbia Basin, Pacific Northwest Quarterly, Vol. 27 (1936), 99-152.

7 Francis Haines, The Northwest Spread of Horses Among the Plains Indians, American Anthropologist, Vol. 40 (1938), 429-437. 
and east. Expeditions to the buffalo range far to the southeast now became annual affairs, often marked by intermittent fighting with Plains culture tribes. Increased contacts with these alien peoples brought further changes. The Indians of the Columbia took over many of the Plains "horse culture" characteristics, especially the techniques and rituals associated with warfare. Wealth and prestige became bound up with horses and war. Access to the buffalo and increased range and efficiency of hunting enhanced economic security, and this in turn allowed larger groups to live together. Numerous autonomous fishing villages tended to amalgamate into organized bands, necessitating political and social change, and over-all populations probably began to increase. ${ }^{8}$

The rich interior grasslands took on new importance as the horse herds thrived and multiplied on the nutritious bunchgrasses. Movement of people over the land also increased dramatically. Narrow footpaths were incised more deeply into the terrain as the horse hoofs marked the way for later travelers. The size of the herds and the fine condition of the horses always impressed white observers. Meriwether Lewis, in his journal entry for 25 April 1806, noted:

It astonished me to see the order of their horses at this season of the year when I knew that they had wintered on the drygrass of the plains and at the same time road with a greater severity than is common among ourselves. I did not see a single horse which could be deemed poor and many of them were as fat as seals. ${ }^{9}$

\footnotetext{
8 Meinig, 24.

9 Gary E. Moulton, ed., The Journals of the Lewis \& Clark Expedition,

(Lincoln: University of Nebraska Press, 1983) Vol. 7, 166.
} 
Wilson Price Hunt reported "at least two thousand horses" on the upper Umatilla River in January 1812.10 Alexander Ross, traveling up the Columbia River for the Pacific Fur Company, stopped at a large Indian camp at the mouth of the Walla Walla and noted, "The plains were literally covered with horses, of which there could not have been less than four thousand in sight of the camp."11 Overton Johnson and William Winter recorded in their journal of the 1843 immigration:

This is the country of the Walawala Indians. They own a great many horses; some of them have as many as two thousand - and they are the finest Indian horses we have ever seen. 12

Another member of the 1843 party made a diary entry on October 5th that reflected a problem caused by the numbers of Indian horses: "Delayed some time in camp this morning hunting cattle and horses, many of the latter having wandered off and the Indian horses being so numerous made it difficult for us to find our own."13 Anthropologist Eugene Hunn lists twenty-five distinct Sahaptin words for horses of differing varieties and descriptions

10 Hoyt C. Franchère, ed. and trans., The Overland Diary of Wilson Price Hunt, (Ashland, OR: The Oregon Book Society, 1973), 53

11 Alexander Ross, Adventures of the First Settlers on the Columbia River, (Ann Arbor: University Microfilms, Inc., 1966), 127.

12 Overton Johnson and William H. Winter, Route Across the Rocky Mountains, with a Description of Oregon and California, reprinted in Oregon Historical Quarterly (OHQ) Vol. 7 (March 1906), 96.

13 James W. Nesmith, Diary of the Emigration of 1843, OHQ Vol. 7 (March 1906), 354. 
that are still in the lexicon, indicating lasting interest in horse culture. ${ }^{14}$

One of the main Indian highways, the great "Nez Perce trail," was described by pioneer missionary H. K. Hines:

This trail was the great highway of the Walla Wallas, Cayouses and Nez Perces eastward to the buffalo ranges, to which they annually resorted for game supplies. . .It was worn deep and broad, and on many stretches on the open plains and over the smooth hills twenty horsemen could ride abreast in parallel paths worn by the constant rush of the Indian generations from time immemorial. ${ }^{15}$

Historian T. C. Elliot, writing of the famous road between Fort Walla Walla and Fort Benton, Montana, emphasized its true origin: $\mathrm{Be}$ it remembered that, speaking broadly, this Mullan Road followed the meanderings of one of the old and well traveled Indian trails. . ."16

The economic pattern of the three tribes required a seasonal cycle of travel about their respective territories. In the winter, they lived in villages on the Columbia, Walla Walla, and Snake rivers, or in the lower valleys of their tributaries. In the spring, they moved southward into the Blue Mountains to dig roots and catch spring salmon in the headwaters of the mountain streams.

14 Eugene S. Hunn with James Selam and family, Nch'i-Wána, "The Big River": Mid-Columbia Indians and Their Land, (Seattle: University of Washington Press, 1990), 26.

15 Quoted in William Parsons and W. S. Shiach, An Illustrated History of Umatilla County and of Morrow County, (W. H. Lever, 1902), 20-21. Hereafter cited as Parsons, History of Umatilla County.

16 T. C. Elliot, The Mullan Road: Its Local History and Significance, The Washington Historical Quarterly Vol. 14 No. 3 (July 1923), 207. 
In the summer and fall, they moved even farther back into the mountains, gathering roots and berries, fishing, hunting elk, deer and fowl, and pasturing their livestock. In the winter, they returned to their winter camps along the rivers. The "travois," or "traka," two lodge pine poles pulled behind a horse, could carry belongings, children or the old or ill, in the absence of wheeled conveyances. This cycle was repeated year after year, and the members of the tribes used the same village and camp locations along the seasonal routes of travel each year. ${ }^{17}$

By either canoe or on horseback, Indians would travel from the Umatilla Country downstream to the great market on the Columbia, at present-day The Dalles. Tribal members from all directions gathered to feast and barter. All types of goods foodstuffs, weapons, craft items, canoes, slaves, horses - were exchanged. Another site of bartering was the Grande Ronde Valley, which was also the gateway to and from the Snake River Valley. Many well-used paths existed across the Blue Mountains to connect the Walla Walla and Umatilla valleys to the Grande Ronde. 18

17 Robert J. Suphan, "Ethnological Report on the Umatilla, Walla Walla, and Cayuse Indians Relative to Socio-Political Organization and Land Use," reprinted in Oregon Indians II, D. A. Horr, ed., 336-338. Originally docket number 264, defense exhibit number 18 , before the Indian Claims Commission.

18 Oscar O. Winther, The Old Oregon Country, A History of Trade, Transportation, and Travel, (Lincoln: University of Nebraska Press, 1950; reprint, Bison Books, 1970), 9-13. Hereafter cited as Winther, The Old Oregon Country. 
In addition to canoe travel up and down the Columbia River, Umatilla Indians at the mouth of the Umatilla River were available throughout the year to ferry people and goods across the river to connect with a major road on the north bank of the Columbia. These boatmen preferred canoes made by the Spokane tribe to the north, as no trees existed in reasonably close proximity to the navigable waters of the Umatilla Country. 19

There has been an attempt by members of the Confederated Tribes of the Umatilla Indian Reservation to locate and identify ancestral summer camp sites in the Blue Mountains. Archeological sites are not identified due to the fear of depredations by looters; however summary reports are on file at the reservation headquarters. These sites were used annually by family groups. Trails to and between them were well-established. In the camps the women would dig and gather roots, medicinal herbs and berries while the men would set up sweat lodges and hunt game in the surrounding mountains. In pre-contact times, there were many more runs of native anadromous fish than there are now, and the stocks of these and other species were plentiful. Indians would go to the headwaters of the Umatilla and Walla Walla rivers and their tributaries to harvest fish. 20

19 Interview with Thomas E. Bailor, Bureau of Indian Affairs Cultural Resources Technician, Confederated Tribes of the Umatilla Indian Reservation, 14 December 1995. Hereafter cited as Bailor Interview. Bailor was a rich source of information regarding the seasonal movement of Indians in the Umatilla Country.

20 Bailor Interview, 14 December 1995. 
Despite the anthropological findings for Indian mobility in this region, it is difficult, if not impossible, to go into the field and designate a physical contour or trace as an "Indian Trail." Natural processes have caused many to disappear over the years. Many were noted on early plat maps as "Indian Trail," or simply "Trail," or a dotted line. But the fate of many of the trails, certainly the fate of the major Indian highways, was to be assumed by immigrants and settlers. They became pack trails; then, if the grades and courses were suitable, they became wagon roads. Centuries of use on foot, and then decades of heavier use on horseback, had led Indians to find routes that combined directness and ease. Of course changes were necessary over time. A rock slide, a flash flood, even a downed tree would cause a detour; but the new routes were quickly established. Subsequent chapters will document the use of these trails by the incoming white men and women, and the lasting impact of the early patterns of human movement. 


\section{CHAPTER 3}

\section{MOVEMENT OF EXPLORERS, TRAPPERS, AND TRADERS}

White men did not look on the Umatilla Country as a destination; it was an obstacle to be overcome, either as mountains to be surmounted or an arid plain to be crossed. The exception to this opinion occurred during a relatively short period when there were still fur-bearing animals to trap on the Umatilla River and its tributaries, or on the streams flowing out of the Blue Mountains. The accessibility of this area led to the early exhaustion of the resource; thereafter, the Umatilla Country reverted to a region to be passed through on the way to another destination.

Early explorers passing through Umatilla County used two principal routes. They could travel on the Columbia River, the great natural highway of the Northwest, or they could travel overland. Either route offered challenges.

When the Lewis and Clark expedition came down the Columbia River in October 1805, until they reached the Umatilla Rapids the only feature of present-day Umatilla County visible to them was the steep basalt cliffs of the Wallula Gap. On 19 October William Clark climbed to the top of the cliffs on the south side, but 
made only a brief observation: "I assended a high clift about 200 feet above the water from the top of which is a leavel plain extending up the river and off for a great extent." 21

On their return trip up the Columbia, the party traded canoes for horses after they passed the great Indian market at The Dalles. That leg of the journey on land proceeded up the north bank, so they did not comment on conditions in the Umatilla area. In April 1806 they traveled a well-used road and Clark complained of the dust raised by a group of several families of Indians traveling just ahead of them. ${ }^{22}$

The next down river exploration was led by David Thompson of the North West Company. He hoped to find a useful passage for the interior fur trade to the Pacific Ocean. He found the area between the mouth of the Snake River and Celilo Falls "poor and sandy, with a very rocky road along the left bank below the cliffs." 23 His map of the northern portion of the Columbia River system is surprisingly accurate in depicting water courses, but includes neither the Blue nor the Wallowa mountains. 24

21 Gary E. Moulton, ed., The Journals of the Lewis \& Clark Expedition, Vol. 5, (Lincoln: University of Nebraska Press, 1988), 298. Note that in direct quotations the original spelling and punctuation is used in this thesis.

22 Moulton, Vol. 7, 171.

23 T. C. Elliott, ed., Journal of David Thompson, OHQ, Vol. 15 (June 1914), 120.

24 Reproduced in D. W. Meinig, The Great Columbia Plain, A Historical Geography, 1805-1910, (Seattle: University of Washington Press, 1968), Map 6, 40. 
The Blue Mountains were a formidable obstacle. The first overland expedition to cross was a party sent by John Jacob Astor's Pacific Fur Company. This party intended to meet a larger contingent at the mouth of the Columbia, sent in the Tonquin, which sailed via Cape Horn and the Sandwich Islands, arriving on 24 March 1811. The overland party, led by Wilson Price Hunt, close to exhaustion, crossed the Blue Mountains in January 1812. Following horse trails for six days, often in waist-deep snow, they finally emerged on 6 January and sighted the great Columbia Plain and the Umatilla River Valley below them. Hunt wrote: "On the 19th, I continued to descend the Euotalla [Umatilla]. Beaver must be common because many places are full of their dams. . .I greatly pleased [the Indians] by stating that I would return to them with goods to barter for beaver." They rested there among the Cayuse Indians and traded for horses before proceeding on to Astoria, finally arriving on 11 May 1812. Hunt's recollections of the trip, written later, are imprecise and often contradictory as to the route taken. It is likely that his party followed Indian trails from the time he emerged from the Blue Mountains. He wrote: "I crossed the [Columbia] river because I was told that the trail ran along the right or north bank. . . The trail along the river was very good."25

25 Philip Ashton Rollins, ed., The Discovery of the Oregon Trail, Robert Stuart's Narratives, Appendix A, Journey of $\mathrm{Mr}$. Hunt and His Companions from Saint Louis to the Mouth of the Columbia by a New Route Across the Rocky Mountains, (New York: Charles Scribner's Sons, 1935), 303-304; Washington Irving, Astoria, (Portland: Binfords \& Mort, undated "Clatsop Edition"), 283-286. 
The next month, Robert Stuart of the Pacific Fur Company, departed from Astoria for New York with dispatches for John Jacob Astor. At the mouth of the Umatilla he noted that the stream was "well stocked with the Furr'd race [beaver]," but rather than travel up that river, the party instead continued up the Columbia to the Walla Walla river where he noted "a good many beaver and otter." They traded with the Indians for horses, then proceeded overland to the foothills of the Blues. It was the first week of August and they suffered in that arid region. They eventually came upon a river, the Umatilla again, refreshed themselves, and crossed the rugged mountains and continued their eastward journey along the approximate route of what would become the Oregon Trail.26

In the notes to Robert Stuart's narrative, editor Philip Rollins carefully traces the party's progress through the Umatilla River and Blue Mountain region. He surmises that Stuart reached McKay Creek, south of present-day Pendleton, by following "an indian trail of patently great age" down Sumac Gulch. Then, "Stuart .. . doubtless pursued an indian trail which-today ancient, still visible and in places worn to a depth of three feet . . 27

These earliest explorations established that, with proper planning and provisioning, the Columbia could be reached via an overland route, and that fur-bearing animals, noticed by Wilson

26 Rollins, lxx-lxxi, 61;

27 Rollins, 89, notes 21, 25. 
Price Hunt and Robert Stuart among others, were available for exploitation. 28 The region quickly became well-traveled by trappers, particularly after 1813, when the North West Company took over the Pacific Fur Company.

In 1818 Donald McKenzie led a band of North West Company trappers up the Columbia from Astoria to the mouth of the Walla Walla River where on 18 July he began the construction of Fort Nez Perce. This fort became a natural center for the far-flung fur empire that embraced the Umatilla Country as one of its most accessible regions. In September, leaving the fort in the charge of Alexander Ross, McKenzie led an expedition southward across the Umatilla River and the Blue Mountains toward Great Salt Lake. He had with him fifty-five men, 195 horses, 300 beaver traps, and a substantial stock of trading goods. Ross, meanwhile, began the practice of trading blankets and other manufactured goods to the Indians in return for pelts. ${ }^{29}$

The year 1820 was McKenzie's most successful. He returned with 154 horses loaded with pelts. His caravan had been joined by a band of Cayuse to total up to 500 horses in a line more than two miles in length. After remaining only twelve days, the

28 Alexander Ross, Adventures of the First Settlers on the Oregon or Columbia River, ed. Milo M. Quaife, (New York: The Citadel Press, 1969), 252.

29 Alexander Ross, The Fur Hunters of the Far West, ed. Milo M. Quaife,

(Chicago: R. R. Donnelley \& Sons Company, 1924), 162, 174-178. 
tireless McKenzie set out again with a party of seventy men to the fur-rich Snake River country. 30

This was McKenzie's last expedition. A party led by Finan McDonald set out in the spring of 1823 , then a larger party in November under Alexander Ross with fifty-three men and 392 horses. On this outing they came across a group of seven Americans in the Snake River country led by Jedediah Smith. Ross noted in his journal: "[I] rather take them to be spies than trappers." They all returned to Spokane House. The take of 5,000 furs and the appearance of the Americans convinced Ross that trapping must be intensified in that region. In his report, he recommended that the base of operations be moved from Spokane House to Fort Nez Perces to more efficiently exploit the rich resource. ${ }^{31}$

The North West Company had been absorbed into the Hudson's Bay Company in 1821, having monopolized trade in the region since 1813. Its importance to the Umatilla country was the establishment of Fort Nez Perces and the annual trapping expeditions over the Blue Mountains to the Snake River country. This orientation of routes of transportation was continued by the Hudson's Bay Company. ${ }^{32}$

30 Ross, The Fur Hunters of the Far West, 256-257, 267.

31 Alexander Ross, Journal of the Snake River Expedition, OHQ Vol. 14 (December 1913), 385; W. T. Atkin, Snake River Fur Trade, 1816-1824, OHQ Vol. 35 (December 1934), 303-312.

32 Meinig, 65. 
After touring the Columbia region in 1824, Hudson's Bay Company governor George Simpson ordered various important changes in operation, not the least of which was the requirement that employees at Fort Nez Perces and the new Fort Vancouver grow their own vegetables and grains, and undertake whatever other horticultural activities that would reduce the operating costs of the department. The introduction of agricultural efforts in the Columbia Basin would have significant impact as the years wore on.

Simpson determined to continue the Snake country expeditions but was not satisfied with the management of that brigade under Alexander Ross, a "self sufficient empty headed man." He offered the job to Peter Skene Ogden, who accepted with enthusiasm and led the expeditions to the Snake Country from 1824 to 1829 , always with Fort Nez Perces as its starting and finishing point. Simpson also noted that for the season ending in 1824, Fort Nez Perces accumulated 2,000 beaver skins, principally by trading for them from the Cayuse. He did not find this arrangement very satisfactory, however; the Indians would only hunt the animals when they needed supplies. They felt that trapping was an unmanly activity. Also, the Cayuse could obtain most of the goods they needed by trading for the 100 to 250 horses needed by the Hudson's Bay Company annually. Simpson sent men to explore the Blue Mountains more thoroughly. Fort Nez Perces would become central to the whole pattern of 
commerce and transportation. Accelerated trapping of the whole region would also serve to discourage Americans from entering the area. $^{33}$

Fort Nez Perces was a key establishment. Its role is welldescribed by George Simpson:

This Post has never been very productive, as the country in its neighborhood is not rich, and the Natives who are a bold Warlike race do little else than rove about in search of Scalps, plunder and amusement. It is necessary however, on many accounts to keep on good terms with them, and to maintain a Post for their accommodation whither it pays or not, as in the first place, they from their numbers and daring character command the main communication; in the next place, our Snake Expedition usually passes through their Country to its hunting grounds, which they could not do if we were not on good terms with them; in the third place, we depend on them principally for an annual supply of about 250 Horses, and finally, the Trade in Furs altho' falling off pays tolerably well. 34

The value of the region was as a nexus of communications and transportation and as a source of the means of transportation the horses, which were only available from the Indians from the area of the Walla Walla and Umatilla rivers. The Chief Factor and staff at Fort Nez Perces were kept busy throughout the year

33 Frederick Merk, ed., Fur Trade and Empire: George Simpson's Journal, (Cambridge: Harvard University Press, 1931), 46, 54-55, 294-295, note 118 , and 308. These last two page references are to two dispatches, one to Simpson from the Hudson's Bay Company Governor and Committee dated 16 January 1828 , the other from Simpson to Dr. John McLoughlin dated 15 March 1829. Also, Meinig, 86.

34 Simpson Dispatch, 1829, quoted in Meinig, 84-85. 
trading for and tending to horses, assisting passing river and overland traffic, assembling equipment and supplies for the annual Snake brigades, and producing whatever farm provisions they could.

For the 1830-31 expedition, the Hudson's Bay Company brigade was turned over to John Work. He led the party of 115 out of Fort Nez Perces on the normal route to a camp near present-day Weston, Oregon. They then followed the approximate route of highway 204 through Tollgate and over the summit of the Blue Mountains into the Grande Ronde Valley and on to the Snake River Country. Work noted that his party made 18 to 20 miles on the day they crested the summit, "the road though steep and in some places a little stony in general not bad." $\mathrm{He}$ also wrote, "Four Cayouse Indians are going the same road as us to the buffaloe and keep company with us. . . That they were able to make that much progress through very rugged terrain, and that it was the normal route used by Indians to and from their hunting grounds, indicated the well-traveled condition of the road. 35

The general increase in movement during this period utilized existing Indian trails. Winter was the busy time for trapping and trading within the seasonal cycle. The wear of the trappers' heavily-laden horses, in addition to traditional seasonal

35 Francis D. Haines Jr., ed., The Snake Country Expedition of 1830-1831, John Work's Field Journal, (Norman, OK: University of Oklahoma Press, 1971), 5. 
use by mounted Indians, created pathways that would be used by travelers for decades to come.

As previously stated, fur-bearing animals in this relatively accessible region of the Umatilla and Walla Walla rivers were pursued steadily, with trappers following Indian trails and blazing new ones in seeking animals that Indians had not previously desired to hunt. Under this steady pressure, the animal populations could not reproduce and quickly declined. The following table gives a clear indication of the early peak and rapid decline of trapping returns from the area of this study 36 :

Table 1

HUDSON'S BAY COMPANY BEAVER RETURNS FOR FORT NEZ PERCES

\begin{tabular}{ccc}
$\begin{array}{c}5 \text { year } \\
\text { period }\end{array}$ & Total & $\begin{array}{c}\text { Average } \\
\text { per year }\end{array}$ \\
\hline $1826-1830$ & 5913 & 1183 \\
$1831-1835$ & 7136 & 1427 \\
$1836-1840$ & 3669 & 743 \\
$1841-1845$ & 1995 & 399 \\
$1846-1850$ & 1222 & 244
\end{tabular}

These figures are for those beaver pelts directly trapped or traded for by personnel of Fort Nez Perces. Simpson's order that the region from that fort to the Snake River country be trapped out

36 This data is extracted from Meinig, Table 1, 88. The beaver returns for all of New Caledonia and the Columbia district showed a similar decline from a yearly average of 18,269 in the first five year period to 6,139 in the last five year period. 
was effectively followed. This is a further indication of the scope of traffic in and coming through the Blue Mountains and the Umatilla Country.

In addition to the movement of trappers, there was a continuous flow of Hudson's Bay Company personnel between Fort Vancouver and the outposts from Fort Nez Perces north, all under the close administration of Chief Factor John McLoughlin.

Historian D. W. Meinig writes: "The life of this intricate system throbbed with the movement of men and horses, provisions, supplies, and documents - an erratic pulsation, varied by season and circumstance." 37 Boats were often used on down river runs, and upriver when the winds were favorable for use of sails. But portages required at the Cascades, Celilo Falls, and Umatilla Rapids made packing by horse more efficient, so well-used roads were traveled on both sides of the Columbia. On the south side, the road followed the Columbia River closely from the mouth of the Umatilla to the mouth of the Walla Walla. ${ }^{38}$

After the demise of Astor's Pacific Fur Company in 1813, British traders enjoyed a monopoly for two decades. After Jedediah Smith, Americans probed the region, either by ship along

37 Meinig, 94-95.

38 Burt Brown Barker, ed., Letters of Dr. John McLoughlin Written at Fort Vancouver, 1829-1832, (Portland: Binfords \& Mort, for the Oregon Historical Society, 1948), pp. 108, 122-123, 132, 199, 201 for example. The volume and varied dates of McLoughlin's correspondence indicates a continuous coming and going of Hudson's Bay Company personnel carrying mail. 
the coast and up the Columbia, or overland into the Rockies. Simpson's "fur desert" held the American trapping parties at bay, but only temporarily. In September 1829, a few Americans were dispatched from a ship to The Dalles to set up a trading camp. The Hudson's Bay Company countered by establishing an outpost on the north bank and undercut the intruders' prices until the Americans withdrew. 39

The arrival of Captain Benjamin L. E. Bonneville and Nathaniel Wyeth at Fort Walla Walla 40 signaled a renewed interest in the Oregon Country. Bonneville, on leave from the Army, led a large expedition into and beyond the Rocky Mountains to trap and reconnoiter. In March 1834 he reached Fort Walla Walla, and the following July again crossed the Blue Mountains to the Columbia, but was rebuffed on both occasions in his attempt to trade in Hudson's Bay Company-controlled territory. 41

Nathaniel Wyeth, inspired by Hall J. Kelley of the Oregon Colonization Society, organized a joint-stock company and set out for Oregon in 1832 intending to trap, trade, and establish a salmon fishery on the Columbia. After a difficult journey, he arrived at Fort Walla Walla on 14 October only to learn that his support ship,

\footnotetext{
39 Meinig, 90-91.

40 Fort Nez Perce had come to be called Fort Walla Walla during the decade of the 1820s.

41 Washington Irving, The Adventures of Captain Bonneville, (Norman, OK: University of Oklahoma Press, 1961), 233, 258-262, 347-349)
} 
the Sultana, had sunk. He spent the winter as the guest of Dr. McLoughlin in Fort Vancouver and returned eastward in the company of a trapping brigade the next spring, meeting Bonneville on the way. Undeterred, Wyeth tried again in 1834, but had no better luck. Unfortunately, his enterprise failed again; he sold out to the Hudson's Bay Company and retraced his steps yet again.

Perhaps more significant than Wyeth's financial failure was the fact that he was accompanied on the 1834 expedition by Methodist missionaries Jason and Daniel Lee, the first of the religious pioneers in the Northwest. By dismissing his parties on both occasions in the Willamette Valley, he left in the wake of his failed trading endeavors men who would be the earliest American settlers in Oregon. Also, he had established Fort Hall in Idaho, to be visited by so many thousands of emigrants on the Oregon Trail in coming decades. As historian Oscar O. Winther wrote: "Fully a decade before Frémont was hailed as the great pathfinder, the man who marked the road to Oregon, Wyeth had traversed this already well-trodden trail four times. . .[He] was Oregon's first successful colonizer. . ."42

This was a time of transition in the Northwest. The coming of settlers and missionaries marked a fundamental change.

42 F. G. Young, ed., The Correspondence and Journals of Captain Nathaniel J. Wyeth, 1831-1836, "Sources of the History of Oregon," (Eugene, OR: University Press, 1899), 172-173; Diary of Jason Lee, OHQ Vol. 17 (September 1916), 254-259; Winther, The Old Oregon Country, 95. 
McLoughlin wrote in 1836 to the Governor and Committee in London: "Every One Knows who is acquainted with the Fur trade that as the country becomes settled the Fur trade Must Diminish . . ."43 The Hudson's Bay Company system was efficient and profitable; it was, however, a commercial system, not a permanent settlement. Meinig provides the following succinct description:

[I]t was all temporary, its roots were shallow, for the human occupation of the land was dependent wholly upon circumstances extraneous to the region itself: upon the furs of distant districts, the ports of the coastal fringe, and the political temper of remote governments. People were here, in posts and camps, moving upstream and down along the old Indian trails and the scabland channels, yet they were here only on assignment, put here, not attracted. In short, in all these twenty years, no one had built a home in this land; no one had settled down to deal with the Great Columbia Plain on its own terms for its own resources. 44

Meinig's reference is to the larger geographic area, but this description is certainly accurate for the Umatilla Country. After the trapping out of fur-bearing animals, other resources were not apparent to those transiting the region. It appeared as arid and infertile, even forbidding and dangerous to early travelers. It would provide the major pioneer highway for immigrants whose

43 E. E. Rich, ed., McLoughlin's Fort Vancouver Letters, first series, (Toronto: The Champlain Society for Hudson's Bay Co., 1941), 172-173; Winther, The Old Oregon Country, 98.

44 Meinig, 95. 
destination was the heralded Willamette Valley; only later would the Umatilla Country become a destination in its own right. 


\section{CHAPTER 4}

\section{MISSIONARIES' IMPACT}

The early American efforts at trade and commerce by Nathaniel Wyeth and Benjamin L. E. Bonneville failed, but the missions and farms took hold. In 1834, Jason and Daniel Lee established their first Methodist mission in the Willamette Valley near present-day Salem, then a second at The Dalles, and a third at Fort Nisqually to the north. Then in 1836, the Congregationalist and Presbyterian sponsored American Board of Commissioners for Foreign Missions ${ }^{45}$ sent Dr. Marcus and Narcissa Whitman and Henry and Eliza Spalding, with others following. Not only did this courageous group include the first white women to cross overland, but they were the first Americans to settle in the Walla Walla/Umatilla area.

The Whitmans' decision to establish their mission settlement at Waiilatpu, on the Walla Walla River, just north of the OregonWashington border, was to be the single most important factor in the development of transportation in Umatilla County. In the history of the Oregon Trail, the impact of the multitudes of

45 Commonly referred to as the "American Board." 
immigrants on the Whitman Mission is well documented.46 In this section, the focus is the relationship of the Mission, the immigrants, and the Indians, and how that dynamic affected the long-term development of transportation in the Umatilla Country.

Although they had not anticipated having to do so, Dr.

Marcus Whitman and his wife, Narcissa, provided a much needed refuge to those weary travelers before the final leg of their journey to the Willamette Valley. After finally emerging from the ordeal of the Blue Mountains, their sight of the settlement at Waiilatpu, with its buildings and gardens, was welcome indeed.

Almost from the establishment of the mission in late 1836, the Whitmans had visitors: Indians, mountain men, Hudson's Bay Company employees, explorers, adventurers, and finally immigrants. Fortunately for historians, the Whitmans, particularly Narcissa, recorded in written form much about the traffic that passed their doors. Some of the visitors also recorded their visits to Waiilatpu in diaries or reminiscences. From the early days, when Narcissa craved the company of visitors, to later years when long wagon trains of hundreds of immigrants exhausted the resources and energies of the missionaries, the Whitman Mission was an outpost on the Oregon Trail. This was not anticipated when the site was selected, but quickly became

46 For example, Clifford M. Drury, Marcus and Narcissa Whitman and the Opening of Old Oregon, 2 Vols, (Glendale, CA: The Arthur H. Clark Co., 1973). 
apparent. Narcissa wrote her mother in the spring of 1840: "We are emphatically situated on the highway between the States and the Columbia River." 47 This traffic, numbering in the thousands, would fundamentally alter the activities of the mission, and at the same time establish long-lasting patterns of transportation in the region. 48

The trickle of those who came earlier on horseback became a flood of immigrants arriving in long wagon trains. Historian Clifford Drury pointed out that there were "more people in the 1843 immigration than were in the combined membership of the Cayuse and Walla Walla tribes."49 The sheer numbers of travelers took their toll on the resources available at Waiilatpu. The key to facing the challenges of feeding those living at or visiting the Mission was agriculture.

The American Board preferred that missionaries restrict their activities to the religious; however, Dr. Whitman quickly realized that he would have to find some means of curbing the Indian's nomadic ways. If they were to be brought into a Christian church and taught what he considered to be civilized behavior, they must be settled. Narcissa wrote: "We are anxious to give them the means of procuring their provisions in a more

47 Narcissa Whitman letter to mother dated 2 May 1840, Transactions of the Oregon Pioneer Association, 1891, 133. Hereafter cited as T.O.P.A.

48 Drury, Vol. 1, 223-224.

49 Drury, Vol. 2, 137. 
easy way, so that there may be less starving ones during the winter."50 Agriculture would provide that permanence.

With seeds brought from home and others obtained from Fort Vancouver, Marcus cultivated sixteen acres of various vegetables during the first spring and added wheat in the fall. Hard work and fertile soil resulted in a sufficient harvest to feed themselves and their visitors, and provide seeds and cuttings to interested Indians. 51

The next year, the acres under cultivation at the mission increased to forty and Dr. Whitman wrote to Rev. David Greene of the American Board that up to one hundred plows and six hundred hoes could be immediately used by interested Indians. It was fortunate that the mission's efforts resulted in such bountiful harvests since it had a continual stream of visitors, some of whom passed through quickly, while others stayed for more lengthy visits. Christian hospitality required that they all be offered food and rest. In his report to the American Board for the year 1839, Dr. Whitman complained of the responsibility: "I do not think it proper for me to hold the most difficult \& responsible station in the mission where all contacts with Traders, Catholics, Travellers \& adventurers of every description come in immediate contact \& where I have to discharge all the duties of Minister \&

50 Narcissa Whitman letter to parents dated 11 April 1838, T.O.P.A., 1891, 101.

51 Drury, Vol. 1, 175, 237. 
Physician to the Mission." In her letter of 2 May 1840, Narcissa noted that the mission was ". . . a resting place for weary travelers, consequently a greater burden rests upon us that upon any of our associates." In the same letter, to her mother, she stated that they had to feed destitute Indians continually. 52

In the fall of 1839 , Wailatpu received a number of visitors on the way to the Willamette Valley, including Thomas J. Farnham. Upon his return to the States in 1841, he published Travels in the Great Western Prairies, giving a vivid description of the bustling activities at the mission. He was greatly impressed by what the missionaries had accomplished in view of the many and varied demands on them as ministers, physicians, teachers, innkeepers, agriculturists and more. Farnham's descriptions became familiar to many in the States who would in future years pass over the Oregon Trail, often through Waiilatpu. 53

In 1840 a group of mountain men and their Indian wives and children made the trip from Fort Hall to the Whitman Mission in the first three wagons to arrive overland in the Oregon Country.

52 Marcus Whitman letter to Rev. David Greene dated 8 May 1838, reprinted in Archer Butler Hulbert and Dorothy Printup Hulbert, eds., Overland to the Pacific, 8 Vols., "Marcus Whitman, Crusader", Vol. 6, Part Two, 1839 to 1843, (The Stewart Commission of Colorado College and the Denver Public Library, 1938), 311, hereafter cited as Hulbert; Narcissa Whitman letter dated 2 May 1840, T.O.P.A., 1891, 133. In the Hulbert work, volumes six through eight are a biography of Marcus Whitman. In each volume the editors published all of the letters, documents and reports regarding the Whitmans and their mission available at the time.

53 Thomas J. Farnham, Travels in the Great Western Prairies, (Cleveland, 1906; reprint, Monroe, OR: Rodney R. McCallum, 1977), 75-79. 
The group included Joe Meek and Robert Newell. The latter wrote: "In a rather rough and reduced state we arrived at Dr. Whitman's station in the Walla Walla Valley, where we were met by that hospitable man and kindly made welcome and feasted accordingly." 54 Newell described a difficult journey, but the fact that the wagons made it through is an indication of the well-used condition of what was a horse trail over the Blue Mountains.

1840 , the year of the "Great Reinforcement," was a difficult one at the mission. The Whitmans were dismayed at the prospect of providing room and board to the many visitors to their crowded settlement. Narcissa wrote: "We are thronged with company now and have been for some time past and may be through the winter. . our house is the missionaries' tavern, and we must accommodate the whole time." It was a real dilemma. The visitors were destitute and could not be turned out. "We cannot sell to them, because we are missionaries and did not come to be traders. . ."55 Dr. Whitman wrote to Greene: "I do not wish to be a supplier for them \& yet I do not see how I can refuse them some grain. . I dare not sell to them. To give them I am not able, and I cannot let them suffer."56 Whitman's dilemma was an indication of the level of traffic transiting the region; also, it is an

54 Remembrance of Robert Newell, T.O.P.A., 1877, 22.

55 Narcissa Whitman letter to mother dated 9 October 1840, T.O.P.A., 1893, 133.

56 Marcus Whitman letter to Greene dated 15 October 1840, Hulbert, Vol. 7, 182. 
indication of the ability of this small settlement to supply the needs of hundreds of visitors.

In July 1841, the mission was visited by Joseph Drayton, a member of the Charles Wilkes Exploring Expedition. His published report gives the next detailed description of Waiilatpu after Farnham's. "They have a fine kitchen garden, in which they grow all the vegetables raised in the United States, and several kinds of fine melons. The wheat, some of which stood seven feet high, was in full head, and nearly ripe; Indian corn was in tassel, and some of it measured nine feet in height." He was much impressed by all that had been accomplished. 57

Two months later, in September, a party of twenty-four immigrants passed Waiilatpu on the way west. One of the company, Reverend Joseph Williams, a Methodist missionary, wrote of the visit: "These were kind, friendly people. . .Here we had all kinds of garden vegetables, which they gave to us very freely."58 The yearly surge of immigrants had begun, comprising men, women and children most of whom arrived tired and hungry at the Whitman Mission from September through November.

The 1842 immigration was led by Dr. Elijah White. He had spent three years at the Methodist mission in the Willamette Valley, arriving by sea in 1837. Difficulties with Jason Lee led to

57 Charles Wilkes, Narrative of the U. S. Exploring Expedition, (Philadelphia: Lea \& Blanchard, 1845), Vol. IV, Chap. 11, 393-395.

58 Quoted in Drury, Vol. 1, 425. 
his dismissal and return to the States, but he managed to get himself appointed as Indian Agent to Oregon. He gathered a group of 105 emigrants at Independence, Missouri and they set forth in a wagon train on 16 May 1842, gaining a few more people on the way. Since White carried important mail for Dr. Whitman, he stopped and spent a weekend at Waiilatpu on his way back to the Willamette Valley. A member of that 1842 emigration party, Medorem Crawford, kept a journal of his experiences. On 11 September, short on provisions, they came to the Grande Ronde Valley: ". . .we found to our great joy [the Indians] had pleanty [sic] and instead of starving as we expected we were able to trade enough fish to last us to Dr. Whitman's." They arrived at Waiilatpu three days later and Crawford wrote that he was never more pleased to see a house or white people in his life. The Whitmans had treated the party with utmost kindness and, having changed the mission policy, sold provisions on "very reasonable terms." The largest portions of the annual immigrant parties would normally arrive when crops were at their most luxuriant, ready for harvest, and the bounty never failed to impress. 59

At this time, immigrant parties still arrived on horseback. Although there were various trails from the Grande Ronde Valley

59 Drury, Vol. 1, 460-461; Journal of Medorem Crawford, entries for 11 and 14 September 1842, reprinted in Sources of Oregon History, F. G.

Young, ed., (Eugene, OR: University of Oregon, 1897), 20. 
over the Blue Mountains, most took the most direct route to the Mission that passed through present-day Tollgate. Certain portions of this route, while fine for horses, were unusable for wagons, so when immigrants began arriving by wagon in 1843, the more southerly route, to be used by so many thousands, was taken. In that first year of wagon trains, Dr. Whitman himself led the party. He had been on the east coast on mission business and on his return journey was able to convince most of the group not to abandon their wagons at Fort Hall, as had been the practice up until that year. Whitman had to leave the group at the Grande Ronde to attend to a medical emergency at the Spaldings' mission in Lapwai. His friend, the Cayuse elder named Stickus, led the train over the Blue Mountains. As a member of the party, J. W. Nesmith, wrote: "[Stickus] was a faithful old fellow, perfectly familiar with all the trails and topography of the country from Fort Hall to the Dalles." 60

The first immigrant wagon train had made the journey into the Oregon Country. Whitman's own estimate of the size of the 1843 immigration was ". . .no less than. . .one thousand persons of both sexes with their wagons, amounting in all to more than one hundred and twenty, 698 oxen and 973 loose cattle." 61 The

60 Gregory M. Franzwa, The Oregon Trail Revisited, 4th ed., (Tucson, AZ: The Patrice Press, 1988), 349-350; Remembrance of J. W. Nesmith, T.O.P.A., 1875, 48. The name "Stickus" was also spelled "Istachus."

61 Marcus Whitman letter to Secretary of War James M. Porter, undated, reprinted in Drury, Vol. 2, Appendix 7, 395-398. 
Oregon Trail was now open. This was something that Whitman had hoped and explicitly worked for. The result was a flood of immigration that increased yearly, the traffic of which continued to tax the resources of the mission, while it established routes of transportation of such permanency that they can be said to still exist.

The Indians saw the opportunity to trade with immigrants for much desired clothing and other manufactured goods. Many responded to the increased traffic by planting their own plots of vegetables. Whitman had a mix of motivations. Since the American Board provided minimal financial support, he saw the traffic as an opportunity to sell provisions to immigrants, thus enabling him to keep the mission on a self-sustaining basis. $\mathrm{He}$ also wished to send them on their way to the Willamette Valley and not have them be tempted to settle permanently in the area of the Indians to whom he ministered. In 1844 he wrote to the American Board:

I was anxious to so manage as to cause the Indians \& the Mission to so far supply the wants of the Immigration in transit as not to force the early occupation of this part. Nothing, however, can long delay such a result. It can do no good to the Indians for us to endeavor to alter the tendency. The Indians want settlers among them in hopes to get property from them. 62

62 Marcus Whitman letter to Greene dated 18 May 1844, Hulbert, Vol. 8, 101. 
The immigration of 1845 saw a significant change. Dr. Elijah White and a small party met the westbound wagon train along the Snake River and recommended they by-pass the Walla Walla Valley and follow the Umatilla River to the Columbia. Dr. White felt that his party had been overcharged for provisions on his previous visit to Waillatpu and did not wish to see the Whitmans prosper. Most of the immigrants followed White's advice and took the shorter route. When he heard of this change, Whitman loaded a wagon with flour and supplies and went to the Umatilla to meet the immigrants. The change in roads, however, was permanent. The cutoff from the western base of the Blue Mountains down the Umatilla River was thereafter the main route; Waiilatpu was now on a side road. The main trunk of the Oregon Trail was now through the heart of the Umatilla Valley. (See Appendix D, Map 2.) 
The Impact of the coming traffic is graphically shown in Table 2:

$$
\text { Table } 2
$$

OVERLAND EMIGRATION TO OREGON63

\begin{tabular}{lr} 
Year & Emigrants \\
1840 & 13 \\
1841 & 24 \\
1842 & 125 \\
1843 & 875 \\
1844 & 1,475 \\
1845 & 2,500 \\
1846 & 1,200 \\
1847 & 4,000 \\
1848 & 1,300 \\
1849 & 450 \\
1850 & 6,000 \\
1851 & 3,600 \\
1852 & 10,000 \\
1853 & 7,500 \\
1854 & 6,000 \\
1855 & 500 \\
1856 & 1,000 \\
1857 & 1,500 \\
1858 & 1,500 \\
1859 & 2,000 \\
1860 & 1,500 \\
\hline Total & 53,062
\end{tabular}

Only a handful of these immigrants did not cross the Blue Mountains and Umatilla County. The iron wagon wheels and the hooves of thousands of oxen, horses and mules, and herds of cattle wore deep depressions into the terrain still visible in some places.

63 John D. Unruh, Jr., The Overland Emigrants and the Trans-Mississippi West, 1840-60, (Chicago: University of Illinois Press, 1979), 119-120. 
It must be remembered that the immigrant parties generally arrived at the Blues from August until November each year and wagons continued to arrive well into the decade of the $1870 \mathrm{~s}$. The Oregon Trail was a crowded thoroughfare.

Many changes had occurred in the Oregon Country during the Whitmans' time at Wailatpu that cannot be covered in any detail in this study. Dr. John McLoughlin had resigned from the Hudson's Bay Company and the boundary question with the British had been settled. Catholic priests had established a mission south of Waiilatpu, on the upper Umatilla River, at the invitation of the Cayuse chief, Tauitowe. ${ }^{64}$ While many Indians had adapted themselves to the more sedentary life of agriculture, many others were alarmed by the changes and were determined to resist. Some of the more demonstrative became insulting and threatening to the Whitmans. Contagious diseases to which they had no natural immunity killed them in great numbers and would lead directly to the tragic events in 1847 . Some thought that Whitman himself was responsible for the deaths by use of poisons. In addition, the immigration of that tragic year was the largest yet, more that one thousand wagons and up to five thousand people, and the Indians were shocked at what appeared to them as an overwhelming invasion. Narcissa wrote to her mother: "The poor Indians are amazed at the overwhelming

64 Francis Fuller Victor, The Early Indian Wars of Oregon, (Salem, OR:

Frank C. Baker, State Printer, 1894), 97. 
numbers of Americans coming into the country. They seem not to know what to make of it." 65

Dr. Whitman made a last effort to keep the immigrants away from the Indian encampments by laying out a new road west to The Dalles. The Methodists had decided to withdraw from that mission and Whitman had placed his nephew, Perrin, in charge. This was the first non-Indian road in the Umatilla Country. All prior traffic had utilized routes based on Indian trails. It was a more direct route going west from present-day Pendleton and, in fact, came into general use despite Whitman's tragic death. 66

The end came on 29 November 1847 in a sudden attack that left Marcus and Narcissa Whitman and twelve others dead. Among forty-seven captives, three more children died. The Whitman Massacre symbolized both the end of the missionary system and the withdrawal of the fur trapping and trading business. All other missionaries were withdrawn from east of the Cascades, including Catholic Bishop A. M. Blanchet, who had established a mission among the Cayuse on the Umatilla. The settlement of the boundary claims provided even more incentive for pioneers to come to the Oregon Country, but continuing Indian hostilities and gold discoveries in California caused a disruption in the pattern of traffic. Meinig interpreted the situation thus:

65 Narcissa Whitman letter to mother dated 4 July 1847, T. O. P. A., 1893, 208.

66 Meinig, 141 
The Indians had reacted to the impact of the white intrusion, and though actual violence had been precipitated by only a portion of one tribe, the shock waves of that explosion had rippled through the entire region, leaving a wake of instability and restlessness, igniting a smouldering tension of fear and defiance. ${ }^{67}$

Military actions against the Indians following the Whitman Massacre occurred for two main reasons: first, for revenge; then to reopen and safeguard the Oregon Trail for immigrants. An isolated attack on a wagon train resulting in loss of life might be tragic, but part of the known risk. The slaughter of the beloved and defenseless Whitmans and Christian women and children at Waiilatpu, and the subsequent hostage-taking and abuse of women called for immediate reprisals. Settlers also realized that if the one overland road to Oregon from the States was closed, they would remain a remote backwater settlement. A continuing influx of settlers was necessary for future prosperity.

Quick and courageous action on the part of Peter Skene Ogden of the Hudson's Bay Company secured release of the surviving captives. Sporadic military action against the various tribes, although not uniformly successful, put sufficient pressure on them that a band of Umatillas captured some who were charged with the murders. Actual guilt was not critical to the settlers in the Willamette Valley; five Indians were hung at Oregon City on 3 June 1850.68

67 Meinig, 151.

68 Victor, 248-251. 
Of the end of the missionary era, Parsons wrote:

[G]rievous as the end of Whitman's career was, it no doubt will ultimately be seen to have produced greater results for this region and the world than if he had survived to enjoy a well merited rest; for the subsequent development of this section, the founding of Whitman College, and the whole train of circumstances arising from American occupation may be seen in some measure to have grown out of the tragedy of Waiilatpu. Here, as elsewhere, martyrdom seems a necessary accompaniment of the profoundest progress.69

The first group of Oregon militia established "Fort Waters" among the ruins at Waiilatpu on 2 March 1848, but the Indians avoided contact. By May, the volunteers were anxious to return to their homes. In order to induce some volunteers to stay and provide a presence until regular army units arrived, the commander, Lieutenant Colonel James Waters, offered them land. In his report, he wrote: ". . .I found it necessary to pledge myself to some responsible men, that I would give them a written authority to colonize the country immediately, securing them as far as in my power against future treaty stipulations prejudicial to their interests." Governor Abernethy approved the action, despite the obvious illegality and contrary military orders. ${ }^{70}$

The soldiers who chose to remain repaired the flour mill, uncovered some large caches of grain, and planted corn and wheat. Herds of livestock were confiscated from absent Indians

69 Parsons, History of Umatilla County, 63.

70 Victor, 216-217. 
and they settled in as bachelor soldier-farmers. They patrolled the immigrant road and by their presence eliminated depredations on the wagon trains of that fall. But as winter approached, either the Willamette Valley or California gold fields beckoned, and all but a dozen or so gave up their dubious claims and departed the WaIla Walla area. ${ }^{71}$

If the Catholic priests J. B. A. Broillet and William Le Claire can be said to have established the first white settlement in Umatilla County on the upper Umatilla River, it was a short-lived achievement. After hostilities had commenced, the two priests left on 19 February 1848 for the safety of Fort Walla Walla, then on to the Willamette Valley. Immediately after their departure, Indians burned the house and destroyed all the property. ${ }^{72}$

The next attempt at settlement was made in 1851 at the Meadows, on the opposite side of the Umatilla River from presentday Echo. Dr. Anson Dart, Superintendent for Indian Affairs for Oregon, established an agency for the Umatilla, Cayuse, and Walla Walla Indians utilizing lumber scavenged from the Whitman Mission. In August of that year a post office was established under the name of Utilla. There had been a permanent Umatilla Indian village there, called "Tko'pa," and the road down the river and the Oregon Trail intersected at that point. In 1855, Fort Henrietta, consisting of a strong stockade, some corrals and wells,

71 Victor, 222-223.

72 Parsons, 156. 
was erected. It was dismantled by the troops in 1857 , at which time the Utilla agency was abandoned, but the intersection of various routes of travel assured that it would be resettled at a later date. ${ }^{73}$

The treaty with the Walla Walla, Cayuse, and Umatilla Indians, as negotiated and written by Territorial Governor Isaac I. Stevens, was signed on 9 June 1855 and ratified on 8 March 1859. In establishing the Indian reservation in what became Umatilla County, the problem of the heavy traffic on the Oregon Trail was supposedly dealt with in Article 5:

. . And provided, also, That in consequence of the immigrant wagon-road from Grand Round to Umatilla, passing through the reservation herein specified, thus leading to turmoil and disputes between Indians and immigrants, and as it is known that a more desirable and practicable route may be had to the south of the present road, that a sum not exceeding ten thousand dollars shall be expended in locating and opening a wagon-road from Powder River or Grand Round, so as to reach the plain at the western base of the Blue Mountain, south of the southern limits of said reservation. ${ }^{74}$

This provision was never fully implemented. The government effort to provide a different emigrant route, the Indian Service Road, is discussed in detail in Chapter 8. Renewed hostilities after the Treaty of 1855, including the Yakima Indian War, delayed further settlement and reduced overland immigration for several

73 Parsons, 156; Suphan, 355.

74 Charles J. Kappler, comp. and ed., Indian Treaties 1778-1883, (Mattituck, NY: Amereon House, 1972), 696. 
years. Those few white settlers in the region fled for their lives; their abandoned homes and improvements were burned to the ground or otherwise plundered. A small settlement at Waiilatpu was also destroyed. ${ }^{75}$ When peace was finally restored, settlers slowly began to return. Joe Crabb, "a sporting man," had the distinction of receiving the first of many licenses to sell liquor in Umatilla County, having established a modest roadhouse where the road from The Dalles to Walla Walla crossed the Umatilla River, near present-day Pendleton. He sold out to Alfred Marshall, and "Marshall's Station" later became the first stage station on the route from Umatilla City, on the Columbia River, to Boise City. ${ }^{76}$

All of the Indian tribes had suffered greatly during the 1840s and 1850s. Deadly diseases decimated their numbers. Those who survived the pestilence and who would have been strong leaders of their bands were often the first killed when they led their braves into battle. Soldiers, settlers, and itinerant scoundrels often stole their livestock and abused their women while overrunning their 800 square mile reservation. The Indians often retaliated. It was a troubled peace and travel was completed through the region with alacrity.

75 Thomas R. Garth, Jr., Waiilatpu after the Massacre, The Pacific Northwest Quarterly, Vol. 38 (October 1947), 315-318.

76 Parsons, 156-157. Umatilla City was also called Umatilla Landing, or, later, simply Umatilla. 
Several significant aspects of transportation during the Missionary Era are worth note. The existence of this outpost attracted traffic in generally increasing numbers. With the exception of the new road that Whitman laid out, the pattern of that traffic was not new, but was superimposed on the route system used by Indians, trappers, and traders. The introduction of wheeled vehicles was new, providing carrying capacity and permanence to the incoming settlers. The mission at Waiilatpu demonstrated the viability of sustained agriculture in a region that had been considered unsuitable for those pursuits. And, finally, the military activities after the massacre made it evident that the region was still extremely difficult to operate in because of the primitive conditions of the roads. 


\section{CHAPTER 5}

\section{THE MINING FRONTIER}

Gold was discovered in Idaho on the Clearwater River in 1860 and the next year on the Salmon River, then on the Powder River in Eastern Oregon, also in 1861. Overland transportation in Umatilla County at that point was summarized by Colonel John $\mathrm{H}$. Raley. He arrived as a boy with his family in a covered wagon over the Oregon Trail in 1862 and later served as county surveyor, so he had a particular qualification to comment on routes and conditions of travel:

There were no "white man roads" to speak of other than the emigrant road which consisted usually of two or three parallel tracks worn in many places to a depth of from one to three or four feet, but the Indian highways of travel were as distinct and well defined as our paved highways of today. They consisted of a parallel line of deep worn trails usually from a bare mark to one or two feet in depth and perhaps from four to a dozen trails in number and two or three feet apart. My recollection of the most prominent ones is of a line leading from Walla Walla river, perhaps from Whitman Station, in a westerly direction over the high ridges and across Juniper Canyon, Cold Spring Canyon and entering the lower Umatilla at the present site of Stanfield. Another well defined line leading from Stanfield in a northerly direction crossed Cold Springs and ended on the Columbia river at Switzler's Island. A main line starting from the south 
side of the meadows. . leading southward across the summit of Table Butte, thence following the ridge between Dry Hollow and Alkali Hollow and past Willow Springs and south to Snipe Valley and Camas Prairie and how much further, I have no knowledge. ${ }^{77}$

Over these various Indian trails and the Oregon Trail poured the throngs of hopeful gold seekers. As historian Leslie M. Scott wrote: "In geography, industry, transportation, politics, the results were far reaching. . ." Prospectors and miners explored the most remote recesses in their search. "They were the advance agents of the succeeding farmers, merchants and transportation men, the geodetic surveyors of their time."78

To refer to "throngs" or "hordes" of miners and prospectors rushing to new gold strikes is not an exaggeration. Concerns about Indian land tenure and treaty rights were overrun in the surge of the gold rush. All possible conveyances and routes were utilized. Scott wrote: ". . .workingmen in all vocations, dropped their implements (1861), secured pack horses for the journey beyond The Dalles, boarded the river steamers of the Oregon Steam Navigation Company and hied them to the Idaho placer fields."79

77 John H. Raley, in Reminiscences of Oregon Pioneers, compiled by the Pioneer Ladies Club, (Pendleton, OR: East Oregonian Publishing Co., 1937), 12-13. Hereafter cited as Reminiscences and the name of the writer of that section. For a brief biographical sketch of Raley, see Parsons, 352.

78 Leslie M. Scott, The Pioneer Stimulus of Gold, OHQ Vol. 18 (September 1917), 152.

79 Ibid., 156. 
Men came from all directions, but for those who traveled or were supplied through routes crossing Umatilla County, the journey started at Portland, the great entrepôt of the gold fields. 80 Irene Lincoln Poppleton, in her history of the Oregon Steam Navigation Company, wrote: "The fleet running to the Cascades was frequently unable to handle the people who arrived on the steamships, and the portage was blocked with freight for days at a time, notwithstanding the fact that double crews were operated." All bills at the Portland docks were payable in U. S. gold coin. 81 The rush to load steamboats made it necessary for wagons to form lines at the Portland docks to deliver goods. Demand often exceeded carrying capacity. 82 This was a tremendously lucrative business that created great wealth for the stockholders. Poppleton calculated that "the cost of moving a ton of freight up the Columbia was ten times greater than moving a ton along any principal water course on the continent." They charged what the market would bear. 83

Table 3 gives an indication of the frenzied traffic on the Columbia River:

80 Winther, 195.

81 Irene Lincoln Poppleton, Oregon's First Monopoly, OHQ Vol. 9

(September 1908), 288, 293.

82 P. W. Gillette, OHQ Vol. 5, 128.

83 Poppleton, 293. 
Table 3

OREGON STEAM NAVIGATION COMPANY
FREIGHT AND PASSENGER TRAFFIC 84
$\begin{array}{lcc}\text { Year } & \text { Passengers } & \text { Tons of Freight } \\ 1861 & 10,500 & 6,290 \\ 1862 & 24,500 & 14,550 \\ 1863 & 22,000 & 17,646 \\ 1864 & 36,000 & 21,834\end{array}$

From Portland, the passengers and freight went upriver to The Dalles, where some traffic departed south and then east on The Dalles-Boise Military Road to Auburn and other gold fields. Most of the traffic portaged at Celilo Falls to re-embark on another Oregon Steam Navigation Company steamboat headed upriver. Umatilla Landing competed with Wallula, at the mouth of the Walla Walla River, as the gateway to the mines. For those who wished to reach the Powder River, the Boise Basin, or the Owyhee mines, the roads from Umatilla Landing over the Blue Mountains were the most direct. ${ }^{85}$ (See Appendix D, Map 2.)

John Hailey was one of the first overland transportation entrepreneurs in the region. Later in his life, he wrote a detailed history of the mining frontier in History of Idaho:

Early in April 1863, the rush to the Boise Basin mines started in earnest from California, Oregon, Nevada, and Washington Territory. Not only miners, but merchants, packers, ranchers, sporting men, lawyers and an occasional preacher were in the throng. Many came by

\footnotetext{
84 Poppleton, 290.

85 Scott, OHQ Vol. 18, 157.
} 
steamer from San Francisco to Portland, and there took the Oregon Steam Navigation Company's steamers for Umatilla or Wallula, as these places were the head of navigation for these mines. . . Some brought saddle horses and a few pack animals, but the majority were without animals, and were not prepared to purchase when they arrived at Umatilla or Wallula. Frequently three, four, or five of them would join together and purchase one pack animal and pack in with their blankets and a small supply of provisions, lead the animal and walk to the Basin. Many would buy a lunch, roll it up in their blankets, shoulder them and 'hit the road' in a few minutes after they landed from the steamer, trusting to replenish their stock of grub at some packer's camp or at some of the temporary stations established on the road for the purpose of collecting toll on some trail or horsebridge and also for selling something to drink. . .

Another class of men. . . preferred to hire transportation for themselves and their baggage and have someone go with them who knew something about the country and the roads, and who would pack a sufficient supply of provisions along for the trip, and when the time came to camp, look out for the animals. This kind of traveling came under the name of 'saddle trains.' . . . The fare for this trip was fifty dollars and each passenger was expected to pay in advance. . . Soon other saddle trains started to carry passengers and the fare was reduced to forty dollars and later to thirty dollars. 86

Out of this fare, the saddle train operator had to pay any tolls, cost of food, and wages for the trainmaster. Loss of animals also cut into any potential profit, but with energy and careful management, the enterprise could be lucrative. Hailey engaged in this business with William Ish in April 1863 and was almost constantly on the trail that year. Hailey estimated the population

86 John Hailey, The History of Idaho, (Boise: Syms-York Co., 1910), 61-62. 
of the mining camps in the Boise Basin in the summer of 1863 from fifteen to twenty thousand; almost every provision had to be packed in from either Umatilla or Walla Walla. Prices on all varieties of goods were shockingly high. John Hailey wrote of prices in 1861 and 1862 that flour was a dollar per pound and "some groceries, such as sugar, tea, coffee, bacon and tobacco, were much higher." In 1863 Alfred Meacham wrote his wife that he had been "cooking meals in a frying pan, and charging a dollar; selling 'flap jacks' two bits each; oats and barley at twelve cents per pound, and hay at ten cents a pound, and other things at same kind of prices; can't supply the demand."87

The winter of 1863-64 was harsh; cold weather and deep snow caused most of the miners to leave the Boise Basin until the next spring. So the men wanting to return to the diggings had to compete with the newcomers who arrived on the first steamboat on 14 February. Business was brisk. Ish \& Hailey sent out a pack train every time a steamboat landed, three times a week. By then, several others engaged in the saddle and pack train business.

87 Hailey, 30, 62-63; Meacham letter quoted in Park Weed Willis, Early Recollections and Impressions of Umatilla County, Oregon, The Pacific Northwest Quarterly Vol. 28 (July 1937), 301-302. 


\section{$\underline{\text { Pack Trains }}$}

The era of the muleskinner and bullwhacker is one of the most interesting and colorful in the history of pioneer Oregon. It was physically demanding and dangerous work, but the lucrative business of supplying the mining settlements kept a steady flow of goods on the roads. Pack trains, or solo prospectors, for that matter, would normally utilize mules, or burros, often of Mexican heritage. It took an experienced muleteer to drive a long train over several hundred miles of rough frontier road. As Winther reported:

Driving mules was obviously no task for amateurs whose clumsiness the animals would not be long in detectingand exploiting. Mules have their mischievous and their stubborn side, and if they choose to exercise it, there is no use arguing, not even cursing. Rather than yield to indecorous motivation, they would prefer to fall, to roll their cargo into the ditch or creek, or start out on a lusty, rampaging stampede. 88

These mule trains ranged in size from thirty to fifty or more, moving in single-file, managed by four or five muleteers. Pack mules ranged in price from $\$ 250$ to $\$ 400$. The packsaddles accommodated an amazing load and variety, including barrels, furniture, train track rails, even a pool table on one occasion. Edwin Benson recalled as a boy living at Ten Mile House that pack

88 Winther, The Old Oregon Country, 178. 
trains of thirty to forty mules passed frequently, and the largest of the mules could carry up to 450 pounds. 89

Herman Oliver grew up in the John Day country and later wrote of the pack mules:

The sturdy little mule saved the day for thousands of miners way out in the ginsengs. This animal "with no pride of ancestry, nor hope of posterity," should have some statues in his honor. He built our western railroads, he fought in our wars, he carried the ammunition that subdued the Indians, but above all, he threaded his surefooted way along every narrow, rocky trail that led to a mine. He should be beatified as the patron saint of all miners. 90

Pioneer missionary James Reynard wrote of the muleskinners:

I must plead guilty to a sneaking admiration of 'packers' (muleteers) and teamsters. These men are wondrous results of the law of demand and supply; for the work demanded they have become thoroughly capable and that work demands strength, skill, daring, endurance and trustworthiness. . Having to lift heavy weights sheer from the ground on to the pack saddle, 'packers' are very muscular men, with grand chests and shoulders. They have also many savage accomplishments: are good farriers, can accomplish marvels with the axe, a screw key and a young sapling for a lever. But they are a godless race both actively and passively. They earn considerable wages, and after a few years settle down in

89 Winther, The Old Oregon Country, 178; Reminiscences, Edwin Benson, 235; James W. Watt, Experiences of a Packer in Washington Territory Mining Camps during the Sixties, Washington Historical Quarterly Vol. 19 (1928), 246.

90 Herman Oliver, E. R. Jackman, ed., Gold and Cattle Country, (Portland: Binfords \& Mort Publishers, 1961), 84. 
some of our beautiful valleys, surrounded by an Indian clientele. ${ }^{91}$

James W. Watt was one of the early packers of the region.

Beginning in 1863, he worked for over two years on the road from

Umatilla Landing to the Boise Basin. In later years, he recalled:

The wages of the packers varied from $\$ 100$ to $\$ 125$ a month, in addition to board. The train master would frequently receive as much as $\$ 150$ a month. Gold dust was then the only legal tender used; greenbacks were at a heavy discount, and in great disfavor. To attempt to pass them as legal tender at par was considered a shady trick. In fact some merchants even went so far as to blacklist and publish the names of persons using greenbacks to discharge obligations incurred at gold prices. Freight and wages were thus always paid in gold and as a result many of the pack trains carried quite an amount of gold dust and they were frequently held up and robbed by road agents. . . I have often come along just after an Indian attack or a highway robbery. 92

Speaking of the route from Umatilla into the Boise Basin,

Watt continued:

These roads used to be lined with pack trains, saddle trains, stage coaches and individual parties on foot or horseback with their pack animals going into or returning from the mines. . . A lot of road houses sprang up along the route to supply food and liquor to the travelers. . . Fully 2,000 mules loaded with freight went out of Walla Walla alone in the next year [1865] with supplies for the Boise mines. ${ }^{93}$

91 Quoted in W. J. Trimble, Mining Advance into the Inland Empire, University of Wisconsin Studies, History Series, Vol. III, No. 2, (Madison, 1914), 256, n. 5.

92 Watt, Experiences of a Packer, 286-287.

93 Watt, 291-292. 
The pack train business brought a unique minority to the Northwest. Many packers from Sonora, Mexico had served in the Rogue River War in Southern Oregon (1855-1856), and some of those men followed the gold strikes to the north and east. As Trimble wrote: "[Pack] trains were generally owned by Americans; but Mexicans, because of special skill, were generally, though not always, the packers." 94 Jesus K. Urquides, of Sonora, Mexico, worked as a packer and freighter in and around Umatilla County. "For more than 60 years I averaged less than six nights in a real bed a year. . . I used to pack all of Cy Jacobs' whiskey from the railroad point [The Dalles] to Boise and received 18 cents a pound." Urquides once packed and drove 100 heavily loaded mules for General Howard during the Bannock Indian War. ${ }^{95}$

It was heavy, demanding work, but anyone with a string of mules had all the business they could haul. Duncan Wright was one: ". . .I bought a pack train and went to Umatilla Landing, where I secured a load of flour and supplies, for which I was paid

94 Trimble, 256, n. 4; Erasmo Gamboa, Mexican Mule Packers and Oregon's Second Regiment Mounted Volunteers, 1855-1856, OHQ Vol. 92 (Spring 1991), 54.

95 Fred Lockley, Conversations with Bullwhackers \& Muleskinners, compiled and edited by Mike Helm, (Eugene, OR: Rainy Day Press, 1981), 248-249. The other distinct minority group was the Chinese. John Bean noted that two or three miles below Umatilla Landing they had a village; Edwin Benson wrote that groups of Chinese would walk to the mines carrying goods balanced on a yoke. Later, a small "Chinatown" existed in Pendleton. Reminiscences, Bean, 70; Benson, 235; Umatilla County Historical Society, comp., A Backward Glance, (Pendleton: E. O. Master Printers, 1981), 152-153. This work is a comprehensive collection of early photographs of scenes from throughout Umatilla County, including those of the Chinese. 
30 cents a pound freight." He later bought a Buckeye mowing machine and took a contract to cut and furnish hay to the Thomas and Ruckel stage line. He also provided hay to pack horses at 25 cents each, often feeding 75 to 125 horses a night. The traffic over the roads of Umatilla County provided many opportunities to make a living. 96

Pack trains were able to get to remote destinations where wagons had no chance to make it. Will McCormmach wrote:

I recall that in 1878 my father and I hauled a load of flour to the mines on the John Day river, known then as the Texas Bar country. Going through Camas Prairie from about where Ukiah is now located, there was no road whatever.

We wound our way around and followed a horse trail, which was the only guiding mark we had. We were able to get within only about a mile and a half of the mines. Then the load was carried by a small bunch of Chinese employees at the mine.

In commenting about the condition of two early trails into the Salmon River country, John Hailey remarked: "I have packed over both of them, and each time I went over one, I wished I had taken the other."97

The lowly mule and muleskinner kept the mines supplied, and thus kept the gold flowing out of the mountains. As Winther wrote:

96 Reminiscences, Duncan Wright, 177-178.

97 Reminiscences, Will H. McCormmach, 162; Hailey, 30. 
Without the rugged packers and their faithful animals, the exploitation of the fabulous resources from. . the Inland Empire would have been impossible. To every gulch and digging, to every camp and placer where enterprising merchants catered to the miners and the necessary and questionable hangers-on, the essentials of life and a few comforts-at a price-were packed by the sure-footed mules. In all seasons, wherever footing could be found, pack trains pushed through. 98

The opportunity for profit in transportation motivated many to begin hauling freight by wagon over the improved roads. This competition forced some of the smaller packers to quit and try something else. Some went into livestock ranching, other into farming. Many stayed in some aspect of the transportation business, caring for the teams of horses and mules, running station houses, harness repair, blacksmithing, or related occupations.

Freighting

Umatilla Landing, the transshipment point on the Columbia River, became the overnight focus of furious business activity. A. J. Kane of Wallula had seen the need for a landing below the head of navigation at the Umatilla Rapids just upriver from the mouth of the Umatilla River. He established a landing eight miles below that point and named it Grande Ronde Landing. He had the right idea but the wrong location. The site of Umatilla Landing, started by Zenas F. Moody, later Governor of Oregon, proved best,

98 Winther, The Old Oregon Country, 201. 
and many businessmen, including Kane, moved there in a rush. By 1865, Umatilla Landing had a floating population of between 1,500 and 1,800, many of whom were engaged in the transportation of men and goods. Lot Livermore wrote of the inhabitants: "Only a few had brought their families with them, so the male population largely predominated." He also wrote that sail barges made occasional trips from above Celilo with fuel and lumber, and that thousands of tons of wild hay was brought in barges from near the mouth of the Yakima River to provide feed for the large numbers of animals. Every effort was made to receive winter stocks by the first day of December of each year, since the Columbia River iced up about that time and remained closed to navigation for one to three months. Another writer noted that as saloons and gambling houses were considered a standard of the prosperity of a town, Umatilla Landing, with twenty-two such establishments, must surely be considered prosperous. 99

John E. Bean worked as a shipping clerk for John R. Foster and Company at Umatilla Landing. He wrote:

Twice a week the freight would arrive and we had to get it hauled from the boat to our warehouse and it had to be all checked over, and then we had to check it out to the freighters. . . A dray team pulled the loads up the steep bank. . . A good size freight team had about ten yoke of oxen or from ten to twelve span of mules. Their progress

99 Mildred Searcey, Way Back When, (Pendleton: East Oregonian Publishing Company, 1972), 34; Reminiscences, Livermore, 26-27. 
of course was very slow and they had to make camp at night and pasture the animals on whatever they could find. Some of the springs and watering places where there were regular stopping places would be very lively at night when there might be several outfits there at once. ${ }^{100}$

Gold dust became the normal medium of exchange and every business house had a gold scale. Downriver steamer traffic was light, but tremendously valuable with increasing bullion shipments, much of it having passed through Umatilla County. A sampling from a lengthy listing provided by Scott: "The river steamer Julia arrived at Portland April 28, 1862, with $\$ 100,000$ in gold dust. The Carrie Ladd, on May 20, 1862, arrived with $\$ 175,000$; again on June 25 , this steamer brought $\$ 200,000$ to Portland." The downriver flow of treasure, reported regularly in the Oregonian, provided constant incentive for the upriver flow of men and materials. 101

Routes over the Blue Mountains (See Appendix D, Maps 2 and 3.)

The miners and their suppliers took four main routes and other minor routes through Umatilla County to the gold fields. The first and most obvious road was the Oregon Trail, only in reverse. It had the advantage of being well-established and supported by a few early settlements along the way. But the traffic was more than one road could handle, particularly during the immigrant seasons when the westward surge of wagon trains

100 Reminiscences, Bean, 66-67.

101 Reminiscences, 35-36; Scott, OHQ Vol. 18, 165. 
met the eastward flow to the mining regions, clogging the road and exhausting the nearby resources.

From Umatilla Landing, the road followed the east bank of the Umatilla River southeast to Echo and then along the north side as the river curved east to Marshall's Station just west of presentday Pendleton, following the old Indian trail. Six miles upriver from Echo, at Corral Springs, the road intercepted the old immigrant road. This was a more direct cut-off eastward, but with a steeper climb. The heavier freight wagons would stay on the more gradual climb by the river. The Oregon Trail divided near the Indian Agency just east of Pendleton. One branch followed the river east, then south up Squaw Creek to Emigrant Springs in the Blue Mountains. The other branch aimed southeast along the main route designated "Pendleton and LaGrande Wagon Road," to Emigrant Springs and points east, following approximately the current Interstate 84 highway. Yet another branch was opened in 1866 branching south from Marshall's Station up McKay Creek, intersecting the Immigrant Road near Meacham. This branch, known as the Hall Trail, passed through the Indian Reservations, and will be discussed in more detail in Chapter 8. A major portion of the Oregon Trail over the Blue Mountains was operated as a toll road by the Meacham brothers, Alfred and Harvey, who worked diligently to maintain the route. After Alfred left in 1869 for Washington, D. C. to accept the appointment of President Grant as Secretary of Indian Affairs, 
Harvey was killed by a falling tree in 1872. His widow married Mr. F. A. Foster and so the section of the Oregon Trail near Meacham became known as the "Foster Toll Road" and is shown as such on a plat map of 1885 . The government effort to maintain the road through the Indian Reservation will also be detailed in Chapter 8.102

The early General Land Office (GLO) maps, surveyed beginning in 1861, are not entirely consistent in designating road names or even in depicting their paths from one township plat drawing to the next. The present-day researcher may trace a road on the microfilm screen, insert the next card and the road might disappear or be a section or two off from its expected course. Considering the difficulties to be encountered by surveyors of pioneer counties, it would be remarkable if discrepancies did not exist. The GLO maps are, however, particularly useful in determining general routes of traffic and also in documenting the number and pattern of new roads within a township over time. ${ }^{103}$

102 Lawrence E. Nielsen, Roads of Yesterday in Northeast Oregon, (Bend, OR: Maverick Publications, Inc., 1990), 114-116, hereafter cited as Nielsen, Roads of Yesterday; Lewis A. McArthur, Oregon Geographic Names, 4th ed., (Portland: Oregon Historical Society, 1974), 486; GLO platbook for Umatilla County, May 1885, J. H. Gerhard, surveyor, located in the Planning Office, Umatilla County Courthouse, Pendleton, Oregon, Range 1 South 35 East.

103 General Land Office survey maps, microfilm files, Bureau of Land Management Office, Portland, Oregon. Specific maps cited as GLO map, township, and year of survey. 
The southern route of the four through Umatilla County was the Daley Road.104 It was a toll road operated by the Blue Mountain Wagon Road Company, incorporated on 25 April 1863. It was used primarily by freighters carrying supplies to the mines in the Granite, Baker, and Auburn areas. It was first opened in July 1864. There were several branches of the road in the Pilot Rock area, including one long stretch up Birch Creek called the Pilot Rock-Granite Road. It was shorter by 25 to 40 miles than the other two main roads, but it was rough and crossed over high elevations. When snow obstructed wagons on the Daley Road in winter, pack trains continued across. It joined the Oregon Trail south of North Powder. ${ }^{105}$

The other two roads took separate routes from the Walla Walla Valley across the Blue Mountains in the northeast of Umatilla County to the Grande Ronde Valley and on to the Boise Basin. Suppliers landing goods at Wallula did not want to be limited to Montana settlements. The Lincton-Woodward Road went from the Fort Walla Walla and Milton-Freewater area to Tollgate, Elgin, and on to Union. The Thomas and Ruckel Road went through Weston and Bingham Springs to Summerville and

104 This road has been spelled in many ways: Daly, Daily, Dayley, Dealy, but Daley most frequently.

105 Lawrence E. Nielsen, In the Ruts of the Wagon Wheels, Pioneer Roads in Eastern Oregon, (Bend, OR: Maverick Publications, 1987), 17-19. Hereafter cited as Pioneer Roads. 
LaGrande. This was the route taken, with some deviations, by the Whitman party in 1836 to cross the Blue Mountains. 106

Samuel Lincton, a sawmill operator, in partnership with later railroad entrepreneur Dr. Dorsey Baker, formed a company to build a road to the Grande Ronde Valley. The Lincton Road met the Woodward Road near Tollgate. David J. Woodward homesteaded in that part of the mountains and by 1875 he had built a fence and hung a gate across the road. The toll was $\$ 1.00$ per team and wagon, $\$ 1.50$ for a four horse team, and 25 cents for a saddle horse. Various charges were also made for sheep and cattle. For this toll, Woodward was obliged to keep the road passable except when snow was too deep. It was heavily used by packers and freighters, then by stockmen in both directions. There were several feeder roads on both eastbound and westbound approaches. Brevet Captain John C. Frémont used much of this route following an Indian trail in October 1843.107 The other important pioneer road from Walla Walla Valley was the Thomas and Ruckel Road. It was built by Colonel Joseph S. Ruckel, a prominent businessman involved in the Oregon Steam Navigation Company, and George F. Thomas, a stage operator of the California and Oregon Stage Line, with H. W. Oliver, Teal Glenn, and Rorah McKinzie also having financial interest. The road

106 T. C. Elliot, The Coming of the White Women, 1836, OHQ Vol. 37 (June 1936), 94-98.

107 Nielsen, Pioneer Roads, 21-22; Mildred Searcey, We Remember, (Pendleton: East Oregonian Publishing Co., 1973), 148-150. 
followed an Indian trail and was similar to the route used by the Marcus Whitman party of 1836.108 From several feeder roads, the Thomas and Ruckel Road went south from Weston to Thorn Hollow on the Umatilla River. From there the road went east, up the river to Bingham Springs, turning southward up Thomas Creek. At the summit, near Ruckel Springs, a toll house and stage station was operated until it was moved to Bingham Springs. The road continued down Dry Creek to the Grande Ronde Valley. This was a difficult road, steep and narrow for many miles. It crossed the Umatilla River at several points and high water destroyed bridges on occasion. But it was at a slightly lower elevation than the Lincton-Woodward Road and so remained open longer during winter months. The Thomas and Ruckel Line offered the only direct stagecoach service between Walla Walla, La Grande, and points east over this road, beginning in 1864 . It was a welltraveled toll road that profited its operators well. After it became a free public road, the feeder road coming south from Weston to Thorn Hollow became known as the "Stage Road from Boise City to Walla Walla." The feeder road up the Umatilla from Pendleton to Gibbon was called the "Pendleton and LaGrande Road." A section

108 Nielsen indicated that the Thomas and Ruckel Road was funded by the government, but this is contradicted by other scholars, notably Gregory M. Franzwa, The Oregon Trail Revisited, 4th ed., (Tucson, AZ: The Patrice Press, 1972), 349. Also, see Searcey, We Remember, 152. Mrs. Searcey writes that the road was financed not by the government but by prominent Walla Walla and Summerville men. There is no dispute that the road followed an old Indian trail, as stated in "News and Comment," OHQ Vol. 18, 299. 
of the Thomas and Ruckel Road crossed the Umatilla Indian Reservation, which will be discussed in more detail in Chapter 8.109

Along the busy roads in Umatilla County, new homesteads and settlements quickly emerged, some with explicit intent, some purely by accident. Among the early settlers of Umatilla County were those directly involved in the transportation business. During winter months, packers and freighters would either find habitation in Umatilla Landing or build a cabin near the Umatilla River or adjacent to one of the roads. Most of the year they were away, on the road to or from the mines. If they were single men, their habitation would often be very simple: a shack near water and pasturage for animals. If they had a family, the habitation would be less primitive: a log cabin with a stove, a garden, perhaps a flock of chickens. These isolated homesteads often represented the start of a small community.

Mrs. Searcey gives an example of a more serendipitous founding of a town - Pilot Rock. "Hookey" Burke, a freighter on his way to the mines, awoke one morning to find a snow storm raging. He made camp on the west bank of East Birch Creek beside a branch of the Daley Wagon Road. The storm did not let up, but since he had all the provisions intended for the mines, he decided to winter right there. Other wayfarers, seeing the smoke of his

109 Nielsen, Pioneer Roads, 22-24; Searcey, We Remember, 152-153;

Searcey, Way Back When, 39; GLO Map, 1885. 
fire visited and he began to sell some of the goods. Winter departed but Hookey did not. Soon others settled in the vicinity and it became known as Mt. Pleasant, later renamed Alta, near present-day Pilot Rock.

One of the first families to settle in the Pilot Rock area was the Hemphill family. Mrs. Hemphill had a garden on a creek, raising grain and vegetables. To get flour, they had to take their grain all the way to the Indian reservation, a two-day trip to the only flour mill in the county. She also sold grain to passing packers and teamsters going to the Granite Creek mines. They bought a work horse from money she made by selling chickens to the mines. This kind of entrepreneurial spirit was common to pioneers of Umatilla County. 110

\section{Wagon Roads and Teamsters}

As the improvement of roads, bridges, and ferries progressed, the packing business would naturally decline as freight wagons and then stage coaches came into use. Often packers would become stockmen, farmers, or operators of stage stations or road houses along the still-busy routes of travel. The muleteers were often replaced by the "bullwhackers", or teamsters, whose large capacity freight wagons led to significant reduction in freight rates. Between Umatilla City and Boise "slow" freight rates dropped from ten and twelve cents per pound to six

110 Reminiscences, Mrs. John Hemphill, 35. 
and eight cents. Wagons were frequently hitched together, three or four in a row, hauled by a dozen or more mules.111

Developments in transportation were often a result of competition. Several attempts were made by California interests to gain a portion of the business supplying the Boise Basin. In 1864 the Idaho and California Wagon-Road Company laid out a route from Red Bluff, California to the Snake River Ferry near old Fort Boise. Another branch of this road started out from Yreka. Heavy losses from hostile Pit River Indians damaged its chance to become a profitable route. In 1865 another, more easterly route, was laid out connecting the Sacramento and Boise valleys. A third route was to follow the Sacramento-Fort Hall immigrant road eastward. 112

The distances over any of these California roads were very long, passing over desolate stretches. For example, from Chico to Virginia City, Montana, the journey was 810 miles. ${ }^{113}$ The shorter routes through Umatilla County continued to dominate, but the competition helped to keep freight rates at a more reasonable level.

The lucrative nature of the mining era transportation business necessitated passable wagon roads. Pack trains gave way to large capacity freight wagons, as has been stated, although

111 Hailey, History of Idaho, 99; Trimble, Mining Advance, 120-121;

Winther, The Old Oregon Country, 214.

112 Winther, The Old Oregon Country, 216-217.

113 Ibid., 217. 
the mules continued in service for several decades.114 In 1863 there were 150 wagons hauling from Wallula to Walla Walla and Lewiston. A new, more level wagon road was built in June 1867 between The Dalles, through Umatilla, to Walla Walla. Called The Dalles-Walla Walla Road, it could accommodate the heaviest freight wagons. Teamsters could go through to Walla Walla, or turn off to the south down the Daley Road, or follow the Oregon Trail over the Blue Mountains, passing through La Grande. The latter route was sometimes referred to as the Meacham Road, after the brothers of that name.115

In the spring of 1863, Alfred and Harvey Meacham established a ranch at Lee's Encampment near the summit of the Blue Mountains. For years they worked to improve and maintain the road, which was well-known as the only route passable during winter. They received a well-earned toll for their efforts.

Meacham's Station did a thriving business with year-round traffic, prompting the brothers to build a hotel famous throughout the region. But even their diligent efforts could not protect the road from the discouraging effects of the weather. Mrs. Pauline Alexander wrote of her stage coach trip over the Blue Mountains in May 1880: "The winter preceding had been very severe with heavy snows, consequently spring was late, with the road over the

114 Mr. Urquides drove his last pack train in 1912. Lockley, 249.

115 Frank T. Gilbert, Historic Sketches of Walla Walla, Whitman, Columbia and Garfield Counties, Washington Territory, (Portland: A. G. Walling, 1882), 262. 
summit breaking up with ice and snow and very rough, owing to freight teams and wagons, which were often mired and stuck in the mud for months."116

The successful establishment of settled communities more often than not depended on the positive impact of transportation at that point in the county. D. H. Mansfield recalled, as an example, that a stage station and blacksmith shop became Centerville in 1878, which then became Athena. Movement meant money. Passing freighters and stage coaches required the services of cooks, bartenders, farriers, hostlers, inn-keepers - the first inhabitants of western towns. ${ }^{117}$

The summer season was by far the busiest, with constant traffic destined for the Idaho and Montana mining towns. Freighters reached Montana destinations by following the Oregon Trail as far as Fort Hall, then northward on a road serving Virginia City, Bannack City, Deer Lodge, and other boom towns. The distance between Umatilla Landing and Virginia City was estimated at 850 to 900 miles. 118

The heavy seasonal traffic on the roads created the need for standard practices, as described by Herman Oliver:

116 Thomas A. Bland, Life of Alfred B. Meacham, (Washington, D. C.: T. A. and M. C. Bland, 1883), 5; Winther, The Old Oregon Country, 219; Reminiscences, 139.

117 Reminiscences, D. H. Mansfield, 71.

118 Winther, The Old Oregon Country, 220. 
Each freight outfit had a set of bells. The bells were clear and loud and fastened to a flat, horseshoe-shaped piece of steel, which in turn was fastened on the hames of the lead team. There were eight to twelve bells in each set.

The bells had two main purposes. The first was to alert an approaching teamster. Roads were narrow then, almost entirely single track. If two of these long freight teams met on a long hill, there was trouble. One might have to back a long distance and that isn't simple with several wagons. One might even have to unhitch. In cases where the drivers heard the bells of another team, each would stop and walk ahead, look over the terrain and decide just how to proceed. There was seldom any trouble about this, because "rules of the road" grew up, based upon courtesy and good sense, and an unreasonable driver was breeding a scab on his nose. .

The other bell function was to warn the other horses in the team. The lead team had to move first, so as their traces tightened, their bells rang, alerting the others. 119

Winther provided the following description of a freighter on the road to the mining frontier:

These well-breaked wagons were pulled by from four to fourteen horses, mules, or oxen with the driver either mounted on the lead horse or seated on the front wagon. If in the wagon seat, he drove by means of a single jerk line attached to the lead horse, an operation aided by a whip and a box of pebbles at the driver's side. The advantage in these enormous wagons and large teams was that fewer teamsters were required. Equipping a freighting concern was a major business enterprise. 120

With quality mules costing up to $\$ 1,400$ a span, wagons from $\$ 900$ to $\$ 1,100$, harness $\$ 300$ to $\$ 600$, and miscellaneous operating

119 Herman Oliver, Gold and Cattle Country, 88.

120 Oliver, 225. 
expenses, a freighting outfit involved a significant investment. However, a train of three wagons would often average 25,000 pounds of cargo per trip. The size of the wagon was indicated by the axle measurement, usually 3 and $1 / 2$ to 3 and $3 / 4$ inch. At eight cents per pound with three wagons, as an example, $\$ 2,000$ in freight charges per trip would quickly provide profit to the transportation entrepreneur. Freighting concerns often operated in long trains carrying many tons of supplies. ${ }^{121}$

It would not be accurate to say that the teamsters, or bullwhackers, were unsung heroes of the West: they sung their own praises whenever possible, and not without justification. They were famed not only for their colorful manners and language, but also for their skill and courage.122 Winther summarized the freighters' impact:

Connections were early made with water routes and later with the railroads. An immense part in the building of the West was played by the wagon freighter-the link between the pioneer era and the agricultural and mineral development spurred by the coming of the Iron Horse.123

The critical contribution of wagon freighting diminished only slightly with the coming of the railroad. Livestock and produce

121 Oliver, 225; William F. Hooker, The Prairie Schooner, (Chicago: Saul Brothers, 1918), 12. Hooker, who worked as a bullwhacker for over two decades in the Trans-Mississippi West, gives the capacities of the "prairie schooners" as between 6,500 to 8,000 pounds. He provides a detailed description of the equipment, composition, and management of these wagon trains.

122 Oscar O. Winther, The Transportation Frontier, Trans-Mississippi West, 1865-1890, (New York: Holt, Rinehart and Winston, 1964), 38-43.

123 Winther, The Old Oregon Country, 227. 
still needed to get to the railheads. Animal traction on the roads of Umatilla County continued well into the twentieth century, until the full integration of motor trucks into the transportation system of the region and the nation. 


\section{CHAPTER 6 \\ STAGECOACH AND EXPRESS TRAVEL}

The rush of population to the mines led to the establishment of two other related transportation activities: stagecoach service and the express business. These activities lagged slightly behind the establishment of the packing and wagon freighting businesses. Passengers sought a more comfortable and expeditious means to get from point to point over long distances. At the same time, a fast and secure means of carrying high value, small volume items became necessary. Consistent with other developments in the transportation history of the region, entrepreneurs quickly emerged to serve, at a good profit, the needs of the public. Passengers, baggage, mail, documents, equipment, and the gold treasure itself needed to be forwarded, and the stage and express businesses were quickly and profitably established.

Stagecoach and express service was not new to the West. Companies such as Russel, Majors and Waddell, Ben Holladay's various stage and express businesses, Wells Fargo and Company, and other enterprises were well known from the TransMississippi area to the West Coast. The first stage line operations in Oregon provided communications between California and the Willamette Valley beginning in 1860. East of the Cascades, two daily stages began operations between Wallula and Walla Walla in 1863. Tri-weekly service began that year between The Dalles and 
Boise over the old Immigrant Road. The following year the George F. Thomas Company started a line over the Thomas and Ruckel Road to La Grande. The Oregon and Idaho Stage Company, almost universally known as Hailey and Ish, or Ish and Hailey (from the surnames of the two principals, John Hailey and William Ish), began operation in 1864 between Umatilla Landing and Boise by way of La Grande, with a fare of $\$ 100$. The leg to La Grande took a day and a half. 124

The first stagecoach used by Hailey and Ish, a Concord, was purchased at Shasta City, California, and driven to Portland. From there it was shipped by steamer to The Dalles and then driven on to Umatilla. These sturdy coaches, built in Concord, New Hampshire, were preferred by passenger and driver alike. The body of the coach rested upon strong leather straps, called "braces," that provided the comfort of suspension. The riders would roll rather than bounce when the coach hit the countless potholes or ruts. The Concord, pulled by two to six horses depending on road conditions and load, accommodated nine passengers on three seats inside, two more on the driver's seat, and up to a dozen more on the top, although baggage and cargo often took up some or all of that space. In the rear was the "boot" which was a leather-covered rack which held mail, express, or smaller baggage. Bullion or other treasure was carried in a box

124 Winther, The Old Oregon Country, 257-258. 
under the driver's seat. A Concord coach cost over $\$ 1,000$ and, if a stage company utilized one, their advertisements "seldom failed to stress the fact. . ."125

The rolling motion of the stage coaches was not appreciated by all the passengers:

The constant pitching from side to side was tough on tender ribs and elbows. The motion roughly paralleled a storm at sea. Effects on the stomach was the same. In good weather, many passengers preferred to ride outside, particularly if there was a sea sick sufferer inside. ${ }^{126}$

But many passengers later recalled stagecoach travel with appreciation, if not fondness. One Lewiston resident gave the following description:

They were jaunty enough in their day, with their cavernous bodies extended behind into a platform or boot for the reception of baggage, and were built high up in front to furnish a throne for the driver, who needed a high seat not only that he might keep a better lookout for the Indians and road agents, but also that he might the better supervise the six horses bounding along under his skilful management. They were not uncomfortable, those old coaches, for the bodies swung on great leather straps which softened the jolt and gave a gentle swaying motion to the heavy contrivance. 127

125 Winther, The Old Oregon Country, 274-275; Reminiscences, Mrs. John Hailey, Jr., 79, David Horne, 59; Dale E. Forster, Oregon Express Companies, (Lake Oswego, OR: Raven Press, 1985), 160, 199, 202, 206, for reproductions of newspaper advertisements for various stage lines featuring Concord coaches.

126 Oliver, 95.

127 Henry L. Talkington, Story of the River-Its Place in Northwest History, OHQ Vol. 16 (June 1915), 189. 
Clara Sayers Stocker agreed: "About the only excitement that we had ... was to watch for the arrival of the stages, which ran from Kelton, Utah, to Umatilla, a distance of 500 miles."128

Mrs. John Hailey, Jr., whose husband and father-in-law were intimately involved in the transportation business, recalled:

There are many persons, especially of the younger generation, who do not appreciate why memory hovers over the old stage coach days. It was a treat to see the stages come in and start out. The spirited horses knew they had to gratify their drivers by showing off. Trunks, baggage and people loaded into or on top of the coach. Good, bad and indifferent folk chummed for the length of the journey, bumped heads and noses, but many lasting friendships were cemented in stage trip days. I have ridden many weary, dusty miles over the old routes. I am glad to have had the experience. . .129

Herman Oliver wrote:

Not too many people are left who ever rode a four- or six-horse stage. I have, and life isn't the same since. ${ }^{130}$

But a stage coach line was more than a quaint conveyance;

it was a business, and competition was keen. Attempts at establishing stage line monopolies in the region were unsuccessful. Because of the vigorous business activity brought about by the gold mining, stage and express companies did not have to rely on government mail contracts for their livelihood as had been the case in other parts of the Trans-Mississippi West. Mail contracts

\footnotetext{
128 Reminiscences, Clara Sayers Stocker, 40.

129 Reminiscences, Mrs. John Hailey, Jr., 79.

130 Oliver, 86.
} 
were prestigious, but not necessary for success. Ben Holladay, "The Stagecoach King," who had the U. S. Mail contract, extended his operation to Oregon in 1864 by letting a subcontract to Thomas and Company for service between Boise and The Dalles through Walla Walla. This was an extension of his line beginning at Atchinson, Kansas through Salt Lake City. It was important in that it was the first direct stagecoach connection between the Northwest and the East Coast. But one daily coach did not come close to meeting the transportation needs of the region, so the stage business remained local, independent, and competitive in the Umatilla Country. ${ }^{131}$

In the spring of 1864 , Ish and Hailey began to run a stage coach from Umatilla to the foot of the west slope of the Blue Mountains three times a week, which was as far as a stage could run due to the poor condition of the road over the mountains. Relays of horses carried passengers and baggage over the mountains to meet another coach on the east side. In the meantime work crews repaired the road, which opened for through traffic in early June 1864. The distance from Umatilla to Placerville, in Boise Basin, was 285 miles. Stations were

131 J. V. Frederick, Ben Holladay: The Stagecoach King; A Chapter in the Development of Transcontinental Transportation, (Glendale, CA: The Arthur Clark Co., 1940). This work clearly illustrates that stage and express enterprises west of the Mississippi relied heavily on federal subsidies. Also, Winther, The Old Oregon Country, 261, 266-267. 
established twenty to twenty-five miles apart to change horses and provide meals. ${ }^{132}$

That same year, George F. Thomas \& Company ran over the Thomas and Ruckels Road from Wallula via Walla Walla to Express Ranch on Burnt River, approximately half way to the Boise Basin. Greathouse \& Company operated the eastern half of the line to Placerville. Hailey noted the competition:

There was a great deal of rivalry between these two lines. Whenever travel was light, rates were often cut down. Time became an object. The line leaving Umatilla in the morning would carry her passengers to the Meacham Station on to the Blue Mountains the first day, a distance of about sixty-five miles. . The other stage line starting from Wallula would only carry her passengers to Walla Walla the first day, a distance of thirty-one miles. So the passengers who took the Umatilla line always arrived at their destination one day earlier than those who took the Wallula and Walla Walla route. ${ }^{133}$

In addition to faster through service, Ish \& Hailey charged lower rates on fast freight and express, and transported treasure at regular freight rates if the shipper would assume all risk. Careful management and good service made Ish \& Hailey the preferred transportation enterprise of the day. In 1865, Ish sold out his interest in the Umatilla to Boise line to Hailey, and bought half interest in the Thomas \& Company line. Later that year, Thomas, Ish \& Company sold out to Hailey and other parties and

132 Hailey, The History of Idaho, 96.

133 Hailey, 97. 
quit the business. By 1867, Hailey dominated the routes from The Dalles, Umatilla, and Walla Walla to Boise, carrying the United States mail and Wells, Fargo \& Company express. In July 1870, John Hailey sold out his operation to the Northwestern Stage Company.134 At the height of their operation, the Northwestern Stage Company used 300 horses, twenty-two coaches, thirty-four stations, and around 150 employees. The horses consumed 365 tons of grain and 412 tons of hay in 1871. Other stage operators in the area were Waldron \& Bigelow, Miller \& Blackmore, and W. M. Ward's Dalles and Umatilla Stage Line. ${ }^{135}$

Mrs. L. J. McIntyre recalled the running of a stage station on the Walla Walla River. Her husband, Jim, and his brother, Tom, owned it, while Mrs. McIntyre cooked for the travelers, most of whom were miners. She charged a dollar a meal, a lot of money in those days. Tom managed the saloon at the front of the station, and Jim handled the horses. They hired men to cut and deliver wood to the army garrison at Walla Walla to supplement their income. Often, the existence of transportation routes made the difference between subsistence farming and the opportunity to earn extra income. ${ }^{136}$

The coming of the railroads spelled doom for the stage lines. By the end of the 1880 s, most routes had been abandoned. The

\footnotetext{
134 Hailey, The History of Idaho, 123-125.

135 Forster, Oregon Express Companies, 180-181; Gilbert, 273.

136 Reminiscences, Mrs. L. J. McIntyre, 49.
} 
East Oregonian, in eulogizing stage driver Charlie Potter, also lamented the end of this colorful era. After his last run, after over thirty-five years driving stages, he did not live long in retirement:

I am as distant from my fellow men now that I am off my box as though I was in another world. I can turn my hand to nothing that fits me. I'm all at sea, out of place, and want to die. ${ }^{137}$

\section{The Express Business}

The express business was closely connected to the stage business, but became thoroughly dominated by one enterprise, Wells, Fargo and Company. The firm continued its practice of appointing local stagecoach operators as its agents so that at nearly every town that had stagecoach connections one could do business with the ubiquitous company. The Oregonian was effusive in its praise:

The people of all new sections are indebted a great deal to Wells, Fargo \& Co., for the facilities afforded by their express to hear from the outside world. Before any mail facilities can be established in the regions that become suddenly peopled through the discovery of gold, and opened up to the commercial and mercantile medium through which business to the amount of millions is transacted. Even after mails are established, this express continues to be the most reliable means of communication for years. Their rates of carrying are greater, but there is no uncertainty about the matter. . We could not hear from the Capital, or any interior town 
on the overland route, were it not for them, and we are greatly indebted to them for favors. . .138

Settlers in the Inland Empire could accept the monopoly of Wells, Fargo and Company a good deal easier than they could the rapacious Oregon Steam Navigation Company.

But Wells, Fargo and Company was not the first express outfit in Northeastern Oregon. The isolation of the mining regions created a need for those lonely men to correspond with their families in Western Oregon and beyond. Also, during the period of the Civil War, everyone was anxious to read accounts of battles, and newspapers were avidly sought. No sooner had these needs arisen than a remedy quickly emerged. These carriers, calling themselves "pony expressmen," often started in business in the manner of Isaac Mossman of Walla Walla. He recalled that in April 1861 he started a pony express to the Oro Fino mines:

With only one pony and $\$ 5$ in money and one pair of blankets, but with plenty of grit, I left Walla Walla about the fifth of April, and started for the diggings. . . and found thirty or forty miners . . . and received a lot of letters to carry back to Walla Walla at fifty cents each. . . I stayed with my little express, and as fast as I came in, bought more horses, and by July augmented my train to ten good saddle ponies. These were scattered along the route at convenient distances, so I could change two or three times a day. 139

138 Oregonian, 15 September 1865.

139 Isaac V. Mossman, A Pony Expressman's Recollections, (Portland: The Champoeg Press, 1955), 27-29. 
Among others to join in the express business over Umatilla County roads were E. W. "Ned" Tracy (Tracy \& Co.'s Express), G. H. Barnett (Barnett's Powder River Express), John Shepherd (Shepherd's Express and Shepherd, Cooper \& Co.), and W. H. Rockfellow (Rockfellow \& Co.'s Express). Once they had established themselves, they would place in the newspapers of Walla Walla, The Dalles, or even Portland, advertisements illustrated with the figure of a galloping pony with his rider leaning into the wind. All of these express companies were bought out by Wells, Fargo and Company in 1863, but while they were in business, they provided a valuable service to the miners. In addition to letters, they carried small packages and gold dust. 140

The movement of valuable treasure over the roadways of Umatilla County attracted the unwanted attention of the robbers, or road agents, who infested the region. In the early years, lone pony express riders had a dangerous occupation, until the stage companies took over the carrying of gold treasure. Even after the stages appeared, road agents were a menace. David Horne drove for the Northwestern Stage Company on a line between Umatilla and Cayuse and recalled that robberies were not uncommon, but he had been lucky and was never held up.141 Lot Livermore recalled:

140 Forster, Oregon Express Companies, 139, 147, 148, 152.

141 Reminiscences, Horne, 59. 
The Pioneer Stage Company ran a daily line of stages from Umatilla to Boise and Wells Fargo \& Co's. Express employed the stage to carry all the bullion consigned to it. I can call to mind many stage robberies on this line of 400 miles. The stage company gave orders to all their drivers that in case of a "hold up they must make no defense, but to obey the orders of the robbers." The reason assigned for this order was that while it [Pioneer Stage] was paid for the transportation of the bullion it was not paid to defend it at the peril of human life. And it is a notable fact that I am unable to recall the loss of a single life where any of these robberies were committed. 142

It was not unusual for stage robberies to net the bandits several thousand dollars in gold dust and bullion. More often than not, the thieves were tracked down by a sheriff's posse or Wells Fargo detectives. ${ }^{143}$

Most remembrances of stage coach travel were much more positive. One of the most experienced stage coach travelers of the day was Carrie Adell Strahorn, who traveled throughout the west with her husband. She had a keen appreciation for what the stage coach meant to a remote region like the Inland Empire:

How much it meant all over the West to hear that cry "Stage!" The sonorous voice of the stage driver, the clatter of hoofs, the creak of heavy brakes, and the grinding wheels as they bumped into the sidewalk, gave notice of the arrival of the daily mail and passengers. All over the western country it was the same great event of

142 Reminiscences, Livermore, 27.

143 Searcey, We Remember, 154-158; Winther, The Old Oregon Country, 286-291. 
the day. Hotel lobbies and sidewalks were full of loiterers waiting for some kind of news to spread through the town, and the idle curious to see who was aboard. ${ }^{144}$

The roads of Umatilla County continued to be busy from March through October each year. Colonel Raley commented on the heavy traffic:

Every road was lined with men on foot, on horseback and, by then, every means of conveyance in a rush to the gold fields. Hundreds of campfires lighted the highway. Stores, saloons, hotels, forwarding and commission houses, blacksmith shops and every manner of business was established as fast as material could be put together for any sort of covering. ${ }^{145}$

The stage and express businesses proved to be efficient means of internal and external communications in both an economic and a social sense. They were vital elements in the system of transportation in Umatilla County and the Pacific Northwest. Traffic over roads, bridges, and ferries in the 1870 s and 1880 s would be a constant movement on foot and horseback, immigrant trains, pack trains, freight wagons, express riders, stage coaches, and army troops. But a complete picture requires the inclusion of herd animal movement over the Umatilla County routes of transportation.

\footnotetext{
144 Carrie Adell Strahorn, Fifteen Thousand Miles by Stage, Volume 1:

1877-1880, (Lincoln: University of Nebraska Press, 1988), 305.

145 Reminiscences, Raley, 14.
} 


\section{CHAPTER 7}

\section{MOVEMENT OF LIVESTOCK}

In addition to supplies and equipment carried by pack train or freight wagon, livestock was another valuable commodity that passed eastward through Umatilla County. Oxen, mules, and horses were sent east to provide for the transportation requirements of the mining districts. Cattle and sheep were driven there to feed the hungry miners, and further east to stock the Great Plains open range industry. Over time, the combination of Whitman's success, condition of the Indian horses, and information from soldiers at Fort Walla Walla convinced some men of the possibility for grazing in the Umatilla Country.

\section{$\underline{\text { Cattle }}$}

Cattle had originally entered the Oregon Country from several sources. The fur companies had all brought various livestock early in the century on board vessels. In 1837, Ewing Young led a party that drove a herd of over 600 cattle and some horses to the Willamette Valley, the first of many cattle drives from and to California. Early missionaries also brought in some livestock, although not in significant numbers. Immigrant parties brought large herds in "cow columns" over the Oregon Trail. The 1843 immigration brought more than a thousand head of cattle. 
Historian J. Orin Oliphant wrote: "In those years people came by the hundreds and cattle came by the thousands."146

The American cattle were superior to the half-wild Mexican stocks from California. Selective breeding along with the lush pastures and mild winters of the Western Oregon valleys, quickly led to a thriving livestock activity. 147

East of the Cascades, Indians began to acquire cattle, first from the Hudson's Bay Company, then from missionaries. These were few in number, however. The real start of the Eastern Oregon livestock industry began when Indians traded fattened cayuse ponies to weary immigrants for lean, exhausted cows. These animals quickly recovered on a diet of the nutritious bunchgrasses of the Columbian Plateau. By the time of the Indian War of 1855-1856, the Indians had, in addition to thousands of horses, substantial herds of cattle. The punitive nature of the war, however, led not only to the Indians' placement on a reservation, but also to the loss of most of their real wealth - their livestock. Soldiers, immigrants, or miners could take whatever animals they came across with virtual immunity. 148

The gold rush to California had established beyond doubt that trade in livestock could handsomely reward a stockman.

146 J. Orin Oliphant, On the Cattle Ranges of the Oregon Country, (Seattle: University of Washington Press, 1968). For the introduction of cattle into the Oregon Country in general, Chap. 1; for details of immigrant livestock numbers, 30-32.

147 Oliphant, 32.

148 Ibid., 36-38. 
Oliphant estimates that each year in the decade of the 1850 s from 10,000 to 20,000 head of horned cattle and sheep were driven from Oregon to California. The Oregon cattle provided more beef and much more milk than the California animals. But since even larger drives were arriving in California from the Midwest, by 1859 there was a glut of livestock and many other agricultural products in Oregon. The resultant economic depression in the Willamette Valley was short-lived.149

The gold strikes of the Northwest and British Columbia provided a new market. Many cattle were shipped by vessel to the Puget Sound and on to British Columbia. Others were offloaded at The Dalles and driven to the Okanogan Valley. And through Umatilla County still more herds headed for the Eastern Oregon, Idaho, and Montana gold fields. Drovers quickly joined packers in supplying the needed provisions.

Beef for consumption provided its own mode of motivation for most of the way - they walked, driven in herds by cowboys. From the start, however, substantial shipments of livestock were shipped by steam navigation up the Columbia, then off-loaded at the Cascades, The Dalles, Umatilla Landing, or Wallula, and then driven on to the mining communities. It was a relatively quick and safe method, avoiding the many problems of a long drive over Cascade mountain passes. Movement of livestock by steam

149 Oliphant, 43-44. 
navigation had been used by westbound immigrants and by eastbound army units since 1852. The gold strikes multiplied this traffic tremendously. The Julia of the Oregon Steam Navigation Company was fitted out for cattle in 1861. Since cattle prices in the Willamette Valley were $\$ 15$ per head, and east of the mountains were $\$ 33$, a clear profit was readily available for those stockmen who could get their animals to the new market. In the first eight months of 1862 more than 46,000 head of cattle were shipped to upriver landing sites. The next year, the Idaho and the Hassaloe began service as stock boats on the middle Columbia. In 1864, the Carrie Ladd and the Iris joined in hauling livestock exclusively. Other steamboats carried partial cargoes of livestock, to the discomfort of some of the two-legged passengers. In 1865, during the first three months of the season, the Julie transported 3,397 head of stock, including cattle, horses, mules, oxen, sheep, and hogs. Even when the rush of passenger traffic declined late in the 1860 s, shipment of livestock remained a lucrative business. 150

In order to avoid the high rates charged by the monopolistic Oregon Steam Navigation Company, many stockmen drove cattle through passes in the Cascades to reach the mines. The rich grasslands of the intermontane region east of the Cascades quickly became a free range on which to rest and fatten the droves of

150 Earl K. Stewart, Transporting Livestock by Boat Up the Columbia, 1861-1868, Oregon Historical Quarterly Vol. 50 (December 1949), 251-259. 
cattle destined for the mining communities. While they fattened, the stockmen could decide which market offered the most profit.

Whether livestock came up the Columbia or over the Cascades, if the destination was to or through Walla Walla or La Grande, the herds came through Umatilla County. Actual routes over the rolling grasslands are not well-known. Herds coming east from either The Dalles or Umatilla Landing would in all likelihood move along the Umatilla River in order to water the animals. Earlier, they could move away from the main roads in order to avoid other traffic and also to provide better feed. The drovers needed to keep a distance from the new and growing settlements in Umatilla County; a herd of cattle could quickly destroy a garden or field of grain. These various requirements kept the movement of livestock mostly out of sight. Later, with the increase in fencing, the droves would have to be moved along the familiar routes of traffic. Minnie Rogers recalled that as a girl in Weston she saw great droves of cattle going through the main street. W. P. Daniel wrote that as a youth in the 1870 s, he saw a five to six mile long herd of 10,000 cattle being driven to Nebraska. All too noticeable was the herd that caused the collapse of the four-year-old, $\$ 6,000$ Main Street bridge in Pendleton in December 1887.151

151 Reminiscences, Minnie L. Rogers, 156 and Daniel, 222; Gordon Macnab, A Century of News and People in the East Oregonian, 1875-1975, (Pendleton: East Oregonian Publishing Co., 1975), 76. 


\section{Cattle Ranching in Umatilla County}

By the end of the 1860 s, pasture land in the Willamette Valley was decreasing as cultivated acreage was expanding. Yearround livestock ranching moved east of the Cascades. The range land was immense and several weeks closer to the mining communities. Walla Walla became the intersection of routes through which many cattle drives passed. Others would use the normal routes of transportation over the Blue Mountains to Baker City, but not without difficulties. Not only would cattle stray in the rugged mountains, but there was often a scarcity of grass and water to sustain the animals.

The establishment of livestock ranching became the vanguard of the eastward movement of colonization, a rebound of human activity into the relatively empty and arid regions of eastern Oregon and Washington. So at the same time the westward migration continued on toward the famous Willamette Valley, another migration began, slowly at first, to move eastward.

The new immigrants first settled in the Walla Walla Valley. The first settlement, close to the old army fort, was at the nexus of communications from all directions. It was a fertile land, wellsuited for livestock raising. That valley and the Grande Ronde prairie filled up quickly, but Umatilla County was close behind. One writer placed the number of cattle in Umatilla County in 1869 at 10,656 . Oliphant wrote that by "September, 1868, there was a feverish buying of cattle in the Walla Walla Valley," and "money 
was so plentiful there that the general feeling was that an 'era of prosperity' was at hand."152 The editor of The Dalles Mountaineer wrote in March 1871, "Almost every evening the O. S. N.

Company's steamer Idaho arrives here loaded down with cattle and horses, and also a large list of passengers."153

By the time livestock ranching became well established in Umatilla County, the demand was decreasing slowly in the mining districts. But two other markets opened up by the mid-1870s: Portland and east of the Rockies. Acreage in the Willamette Valley that had been used for livestock production continued to see a transition to more intensive crop production. At the same time, population growth in Portland and the Willamette Valley created a demand for beef and mutton that was filled by the livestock ranches east of the Cascades. Movement was again reversed as beef, mutton, hides, and wool were shipped down river to Portland. 154

An even larger market for surplus cattle of the Pacific Northwest developed east of the Rocky Mountains. The largest number of these herds were driven on trails leading through the Snake River Valley to passes over the Rockies. From Umatilla County, this meant a continuation of moving droves through Walla Walla or La Grande and on east. These cattle were superior to the

152 Oliphant, 85.

153 Quoted in Oliphant, 91.

154 Stewart, OHQ Vol. 50, 258-259. 
Texas herds and anxious buyers from the Midwest quickly created a sellers' market in the Inland Empire. Horses, mules, and sheep joined this movement, but cattle predominated. By 1878, agents no longer waited in Walla Walla for herds to arrive; they scoured Umatilla County and other ranges of Eastern Oregon and Washington for livestock to be driven east. Oliphant estimated that ". . .at least one hundred thousand head of cattle were driven eastward from Oregon, Washington, and Idaho during 1879.155

Not surprisingly, long cattle drives from the Pacific Northwest quickly diminished when the railroad arrived. Cattle began to move east by the Northern Pacific in 1883 and by the Oregon Short Line in 1884. The cattle ranges of Umatilla County were no longer isolated, either from eastern destinations or from Portland. Before the coming of the railroads, the eastern markets are significant to the study of transportation patterns in that they did not alter routes of movement. Cattle were driven from all over the county over the Blue Mountains and on east to rail connections. After the arrival of the railroads, cattle could be loaded on cars much closer to their ranges. 156

In addition to the impact of the railroads, other factors began to challenge the livestock industry. The population in the mining districts stabilized below the levels of the first rushes and livestock herds were being raised nearer to the demand. But

\footnotetext{
155 Oliphant, 168.

156 Oliphant, 178-179.
} 
beyond the changes in markets, the settlement of the open range meant the end of free movement of cattle and the beginning of ranching. Overgrazing had damaged some ranges and the settlement of farmers had put other areas off limits. Sheep raising, which will be studied in the next section, further crowded the cattlemen. 157

Cattle thieves infested the region until 1885, when a gang of approximately fifteen were arrested and ordered to leave the state. One who did not obey that order with sufficient dispatch, O. H. Stanley, was shot dead on the road from Pilot Rock to Pendleton. A horse thief, George Keach, was lynched on 29 November 1885. Thereafter, while not eradicated, livestock theft was much diminished. ${ }^{158}$

It had become apparent to farmers that wherever the nutritious bunchgrasses grew, wheat would flourish. Meinig described the competition between the stockmen and the farmers:

Barbed wire fences were beginning to cut up the ranges and the stock routes, and the controversy between farmer and stockman now flared over "herd law" legislation. Without fences, wandering stock damaged crops; with them they were themselves injured by the dangerous barbs-who was responsible for the damages in either case? Hardly had the argument become heated before it was ended by passage of "herd laws" which placed liabilities for damage upon the owners of

157 Meinig, 286-287.

158 Reminiscences, Judge Norborne Berkeley, 241; East Oregonian, 1 December 1885. 
trespassing livestock and gave full support to the fence builder. It was a perfect expression of the decisive shift in balance between the farmers and the stockmen in the region. 159

According to Oliphant, American frontier tradition held that all unenclosed land, public or private, was open for grazing. In the wide-open spaces of Umatilla County and the Columbia Plain the lack of timber made fencing a prohibitively expensive burden. And who was responsible for fencing what? Should the farmer be required by a "fence law" to fence his property to protect it from uncontrolled herds? Should the stockman be required by a "herd law" to fence his animals to protect neighboring farmers crops? And how could he fence all public lands? The availability of barbed-wire took some of the vituperation out of the debate as it took much of the expense out of the fencing. By the mid-1880s, barbed wire was readily available and priced within the reach of most settlers. Rail fences disappeared as the timber became posts for the wire. Finally, the farmers came to outnumber the stockmen, and politicians have always been able to count. The complaints of damage to cattle largely fell on deaf ears. ${ }^{160}$ An editorial in the East Oregonian clearly states the situation:

"Burk," writing from Pilot Rock advises stock raisers of Umatilla county not to vote for any man for the next

159 Meinig, 288.

160 Oliphant, 336; Meinig, 300-301. 
legislature who will not pledge himself to work for the passage of an act requiring a pole or board to be hung on all barbed wire fences. Burk, we are sorry to say, is away off on the pole question. Why should poor immigrants coming in here be compelled to haul poles from the mountains a distance of thirty miles to protect other mens' stock? It is hardship enough to be forced to put up a wire fence to save their own crops without having to put a board or pole in also. Stock raising on a large scale is done in this country. ${ }^{161}$

Another editorial stated that stockmen were against any road improvements that would attract new farmers to areas that were still open range land. ${ }^{162}$ Parsons wrote:

Stockmen saw that if these experiments [in wheat raising] should prove successful an industry would be inaugurated which would limit and eventually crowd out their lucrative business, so they did all in their power to discourage the would-be farmers. ${ }^{163}$

But farmers' fences and new roads were not the only concerns of the cattlemen as sheep came to occupy the same range land. Sheep Raising and Wool Production

Two aspects of sheep raising in Umatilla County merit attention. First, the movement of the animals themselves over the terrain; then, the transportation requirements of wool and mutton production. From the early 1840 s, when Dr. Whitman kept a small flock at Waiilatpu, sheep had prospered in the Umatilla

\footnotetext{
161 East Oregonian, 18 April 1884.

162 East Oregonian, 22 August 1884.

163 Parsons, 272.
} 
Country. By the time sheep raising competed with cattle for range, tens of thousands grazed throughout the county.

The Courtney brothers had the first flock of sheep in any considerable number in Umatilla County. Unfortunately, the severe winter of 1861-62 destroyed almost all sheep in the county. After the excitement of the mining rush, Jerry Barnhart, Jeremiah Despain, Jacob Frazer, Samuel George, and Charles Cunningham were among the early sheep raisers, mostly keeping merino varieties. The flocks multiplied so successfully that excess stock joined cattle in drives to the mining districts in the mid- to late-1860s. ${ }^{164}$

Sheep raising was in general contemporary with cattle raising in Eastern Oregon, although the former was held in some disdain. Cattlemen looked on the sheep as a pestilence. Open violence against the herders and their flocks never developed, although threats and occasional acts maintained a palpable level of intimidation for many years. By the mid-1870s, sheep raising had become more lucrative than cattle raising in Umatilla County, partly because sheep could continue to prosper in areas that had been overgrazed by cattle. Also, owners of sheep flocks had less to pay in wages, since two men on horseback and sheep dogs could manage a large flock, many fewer that it took to control cattle herds. Luck and industry could lead to prosperous results.

164 Parsons, 162. 
One of the pioneers of sheep husbandry in Oregon and a recognized authority, John Minto, wrote, "Not rarely a young man starting as herder ended as a wealthy sheep and land owning banker." 165

The business was not without its setbacks, however. Many losses were suffered by sheepmen during the Bannock Indian War of 1878. In their frustration and rage, Indians killed whole flocks and whatever herders they could find in the Blue Mountains, like the unfortunate Charles Jewell, shot and left for dead. Two herders, Ernie Campbell and John Crisp, working for Jeremiah Barnhart, were killed by Indians. Also, when herders fled for safety, flocks would intermingle and a serious outbreak of ovine scabbies developed and large numbers had to be destroyed. But when peace was restored the herds were quickly reestablished.166 Predatory animals took a toll on all types of livestock, but sheep herds were prone to heavier losses, particularly during lambing season. Sheep were the prey of wolf, coyote, bear, dog, bobcat, mountain lion, and eagle in Umatilla County and throughout the West. ${ }^{167}$

It was felt, with some justification, that sheep damaged the range and drove cattle and horses away. Cattlemen bitterly

165 John Minto, Sheep Husbandry in Oregon; the Pioneer Era of Domestic Sheep Husbandry, OHQ 3 (September 1902), 231.

166 Reminiscences, Mary Catherine Baker, 149; Edward N. Wentworth, America's Sheep Trails, (Ames, Iowa: The Iowa State College Press, 1948), 210.

167 Wentworth, 470. 
complained that the "woolies" cropped the grasses so closely that the damaged vegetation would die off. They also believed that the sheep urine and dung would poison the range, since cattle and horses shied away from wherever the flocks had grazed. Cattle and sheep would not graze on the same ground. Also, the sheep kept close together by instinct and tended to eat everything in their path, while cattle wandered apart and would naturally leave range land to replenish itself. As pioneer farmers settled and fenced off more and more of the open range land, cattle and sheep had to share the more rugged and remote regions of the county. 168

The problem was well-stated by the editor of the Walla Walla Union:

Last winter the Legislature passed a law making the owner responsible for any damage done by his sheep on the inclosed land of another. This, however, does not seem to meet the wants of those who have cattle and horses and do not own sheep. They say, and truly too, that a band of sheep turned on the common or outside range where their stock has been used to run is equivalent to depriving them of any outside range at all. And this feature of the case looks hard, for in some neighborhoods where there had been for years large bands of cattle and horses, owned by the settlers, a band or two of sheep has been driven in and the farmers have had to sell their stock because the sheep had run it out of their neighborhood, or else they had to sell their farms

168 Oliphant, 337; Minto, 237-238. 
and take their stock to some place where sheep did not, as yet, molest them. ${ }^{169}$

Free range land had gone by 1890 , although cattlemen were still operating in the rougher areas. Some cattlemen responded to the challenge by moving their stock permanently east, to Idaho, Montana, Wyoming, or even as far as the Dakotas. Those who stayed participated in the universal rural activity of fencing. Farmers fenced off their land to exclude both cattle and sheep. Many wheat farmers ran small sheep flocks in to graze on their wheat stubble fields after harvest, or allowed a sheepman's flock to graze for a fee. Cattlemen fenced, legally or otherwise, large tracts of range land or valuable sources of water, to exclude sheep. The result of all this fencing was that customary routes of movement were altered. Sheep herders needed to move their flocks from summer ranges in the Blue Mountains to shearing pens at Umatilla Landing or Pendleton. Every year they would encounter new detours and surly farmers. Even John Minto, ever an eloquent defender of sheep interests, conceded: "In many localities of our State the annual movement of sheep to and from the mountain ranges causes serious injury to the wheat farmer and homestead settler."170

This problem was partially addressed as the industry matured by performing the shearing of wool in more remote

169 Walla Walla Union, 13 July 1872, quoted in Oliphant, 338.

170 Dexter K. Strong, Beef Cattle Industry in Oregon, OHQ Vol. 41, No. 3 (September 1940), 256; Minto, 233, n. 3. 
locations, thus reducing the need to move the flocks over long distances. The clipped wool was packed in large sacks, then hauled in by wagon over the normal roads that have been discussed earlier in this study. Jeremiah Barnhart, one of the early large-scale sheep raisers, hauled his wool to Umatilla, to be shipped on to Portland.171 The large bulk and low weight of the sacked wool led to the practice of hooking wagons in trains of up to four or five behind spans of horses or mules. Historian Alfred Lomax wrote that,

"[T]he roads, so-called, were dusty and rutty under the trampling feet of thousands of sheep as they moved from the ranches to the shearing and shipping pens and the almost constant friction of the wheels of the heavily loaded freight wagons."172

Boards were inserted to make the high-sided, high-volume wagons commonly seen on the roads from remote shearing sheds to the new scouring mill in Pendleton.

The establishment of the Pendleton Wool-Scouring and Packing Company in December 1893 was a very significant development in the history of Umatilla County. Lomax described the anticipated impact:

". . Pendleton would become an outstanding wool market and commercial center of the region. Roads from ranches,

171 Reminiscences, Mary Catherine Baker, 149.

172 Alfred L. Lomax, Later Woolen Mills in Oregon, A History of the Woolen Mills Which Followed the Pioneer Mills, (Portland: Binfords \& Mort, 1974), 243. 
shearing pens, and feeding grounds led directly to Pendleton."173

The Commercial Club of Pendleton and the Umatilla County Woolgrowers' Association, led by prominent businessmen of the county, solicited for the stock subscription. The mill and warehouse opened for business next to the Umatilla River in May 1894 and within a month freight wagons lined up every work day at the unloading platforms. A railroad siding was quickly laid to facilitate incoming dirty, or "grease," wool, and outgoing scoured wool to be shipped either east or west. The savings on freight charges were substantial since every 1,000 pounds of grease wool left 300 pounds after scouring. After the first seven months, over 3.6 million pounds of unscoured wool arrived at the mill, of which $38 \%$ came by rail from collection points in Echo, Elgin, Heppner, Baker City, Touchet, Arlington, Durkee, Nolin, Union, Walla Walla, and other Inland Empire towns. Just under a million pounds arrived on freight wagons and another 600,000 pounds arrived from Pendleton-area shearing pens. 174

The success of the scouring mill led to the building of the woolen mill in 1896. Grease wool in bales, scoured wool, and finished products were shipped to customers worldwide. Pendleton enjoyed the prosperity of a large salaried work force at the mill who lived, worked, and spent money close to home.

173 Lomax, 245.

174 Lomax, 244-251. 
Umatilla County took justifiable pride in the home-grown industry and its famous woolen products. 175

After shearing, the sheep were either returned to their ranges in Umatilla County, or were trailed east to the feedlots of Kansas and Nebraska. From the range lands in the vicinity of The Dalles, sheep were driven south of Umatilla County along the Dalles-Boise Military Road, then on the Oregon Trail. From Umatilla and Morrow counties, the sheep were driven over the Blue Mountains on the Meacham route. Sheep prices in the Northwest were half of what they were in eastern Wyoming, Nebraska, and Kansas in the last half of the decade of the 1870s. It was the price differential that made the long drives profitable. 176

Hartman K. Evans was a trail foreman on a sheep drive in 1882 and later wrote:

The year I came over the trail, 1882, there was an immense amount of stock of all kinds on the trail-cattle, horses, and sheep. I think this was probably the biggest stock driving year of any, but of this I am not sure. At any rate, stock driving was conducted on such a large scale that prices of all stock in Oregon-cattle, horses, and sheep-began to go up, and the differential between the Oregon prices and the Wyoming prices declined, so that my impression is that the amount of stock on the trail from that time on began to decline. . . on account of the failing differential. 177

175 Lomax, 257-272.

176 Wentworth, 274.

177 Hartman K. Evans letter dated 12 April 1934, quoted in Wentworth, 274. 
Wentworth calculated that the peak of the Oregon drives for all classes of livestock was in 1882, but the numbers of sheep continued to increase until 1897-98. Accurate numbers are difficult to find. On the drive of Evans in 1882, he and his partners purchased 23,000 head of wethers from the vicinity of Pendleton, divided them into three bands, and trailed them to Laramie, Wyoming. They were purchased in Umatilla County for $\$ 1.50$ per head and sold for $\$ 3.00$. His was just one outfit on the trail, albeit a large one. 178

Some details of the Evans drive give an illustration of this type of traffic on the road:

Each band had a foreman, three helpers, and a cook who drove the grub wagon - five men in all. They were accompanied, of course, by the indispensable sheep dogs. Of the fifteen men who started with Evans, only three came all the way through. . . Evans arrived in Laramie with a loss of only 820 sheep out of 23,000 . This was considered a very good record. 179

\section{Horse Raising}

Horse raising remained an important activity in the Umatilla Country. Even after the railroads arrived, this was still "horse country." Dr. Park Willis grew up on a homestead farm on the Lincton Mountain Road and later recalled, "We never walked

178 Wentworth, 274, 277.

179 Hartman K. Evans, Robert H. Burns, ed., Sheep Trailing from Oregon to Wyoming, Mississippi Valley Historical Review Vol. 28, No. 4 (March 1942), 581. 
anywhere that we could ride." Wagons and hacks were pulled and saddle horses ridden universally. Mrs. Lee Moorhouse recalled that "Everybody rode nearly everywhere" on horseback. The horse was as essential to the mobility of the settlers as it had been to the Indians. The Switzler family at one time had their "S" brand on 30,000 head of horses grazing on land on both sides of the Columbia River. "Jehu" Switzler moved horses across the river to and from Umatilla Landing by means of a horse-powered ferry, starting in 1879 , with two horses hitched to a circular drive mechanism to power the craft. Horses pulled a wide variety of vehicles, including sleds, hearses, bandwagons, and fire engines. The market for good horses, for farm, town, or road, remained strong well into the next century. 180

Control of horses was a continuing problem. Even when fenced in, they could jump the rail or wire, or exploit a weakness in the fence. The East Oregonian had a regular column titled "Estray, Lost, Found, Etc." that described missing horses and offered rewards. The value of the horses is indicated by the absence of listings of other livestock species in that column of the newspaper.

The land use pattern of the 1860 s and 1870 s was one dominated by a grazing economy. The livestock industry in

180 Reminiscences, Mrs. Lee Moorhouse, 25; Umatilla County: A Backward Glance, 2, 54, 60; Dr. Park Weed Willis, Early Recollections and Impressions of Umatilla County, Oregon, The Pacific Northwest Quarterly Vol. 28 (July 1937), 306. 
Umatilla County provided a transitional phase between the initial support and service activities of transporting and supplying miners, and the permanent settlement and productive use of the rich agricultural lands. The movement of livestock did not create innovations in transportation systems; the animals and their products moved along established pathways of steam navigation and overland roads that had been in use, with few exceptions, since before the white man. Certain adaptations were made in freighting to accommodate bulk hauling of wool and wheat. The livestock business, in concert with the various transportation enterprises, led directly to the settlement of the region. As the county became the home to full-time livestock ranching, jobs were created and homes were built. Settlements expanded as the need for governmental institutions became evident. 


\section{CHAPTER 8}

\section{IMPACT OF GOVERNMENTAL, SOCIAL, AND COMMERCIAL ACTIVITIES ON TRANPORTATION}

The decade of the 1860 s saw the simultaneous development of county government, social institutions, and commercial activities within Umatilla County. Each of these aspects of human activity relied on and fostered the development of transportation. Establishment of County Government

Under the Territorial Government of Oregon, the Umatilla Country was included in the districts of "Clackamas and Champooick," which were designated as counties after 22 December 1845. On 11 January 1854, all of the Oregon Territory east of the Cascade Range, between the Columbia River and the northern border of California and Nevada, extending to the Continental Divide, approximately 130,000 square miles, was designated as Wasco County. When Oregon achieved statehood in 1859, the eastern boundary of the State became the eastern boundary of Wasco County. The county seat was The Dalles, far away from the mining settlements of Powder River and John Day, and the new settlements along the Umatilla River. The distance and difficulties involved in the travel to The Dalles to transact official business led to the creation of new counties. Eventually, seventeen additional counties were formed from this original 
territory, with Umatilla County created on 27 September 1862, along with Baker County. ${ }^{181}$

A temporary county seat was located at Marshall's Station, opposite the mouth of McKay Creek, just west of present-day Pendleton. There was a ford across the Umatilla River at this site which was used by pack trains from Umatilla Landing heading for the mining country. Also, westbound immigrants passed Marshall's Station, as did eastbound traffic to Walla Walla. In the statute that created the county the Oregon State Legislature reserved to itself the appointment of county officials until an election could be held. The county government consisted of the county court as an administrative and a judicial body, with a county judge presiding and two commissioners. Other officials were named, including a county clerk, sheriff, coroner, and surveyor. The first meeting of the county court was held at Marshall's Station (or, Swift's Station, as it came to be called) on 6 April 1863; however, no records were kept until May of that year. In July, Charles W. Shiveley was appointed first surveyor for the county until E. A. Wilson was elected to that position in June 1864.182

Umatilla Landing had seen rapid growth and as there was no other substantial settlement in the county at the time, the county

181 Frederick V. Holman, History of the Counties of Oregon, OHQ Vol. 11, No. 1 (1910), 51-52, 78-79; Gilbert, 454.

182 Reminiscences, Raley, 13; Commissioner's Journal, Vol. A, 1-5, 40-41, 50. 
seat was moved there in March 1865. Creation of new counties caused sections of Umatilla County to be ceded to Grant County (14 October 1864), and later to Morrow County (16 February 1885) and Gilliam County (24 February 1885). 183

State law set certain responsibilities for counties. Those that are of interest for this study include the licensing of toll roads, toll bridges, and ferries; the designation and vacation of county roads; the operation of private toll roads; surveying land claims and roads; and various other functions that would affect transportation within Umatilla County. All business before the Court was entered by pen and ink in Commissioner's Journals, the volumes being identified by letter starting with "A." Journals that do not have numbered pages are referred to by date of entry. Movement of the County Seat to Pendleton

By 1868 Umatilla Landing no longer dominated the county in terms of population. Weston, Milton, Adams, and Athena had sprung up in the north and east of the county, and settlers were rapidly spreading out from the Umatilla River. Those residents wanted a more centrally located county seat and continued to clamor for a move. On 13 October 1868, the State Legislature passed an act that called for an election to chose between Umatilla Landing and another site between the mouth of Wild Horse and Birch creeks. The debate was vigorous and the vote close, with

183 Parsons, 139; Holman, OHQ Vol. 11, 52. 
394 votes to move and 345 votes to remain. The commissioners named a committee to locate and name the new county seat, which they did: the site was on land donated by Moses $E$.

Goodwin in Sections 10 and 11, Township 2 North, Range 32 East, just east of Swift's Station and the name was Pendleton, in honor of Senator George H. Pendleton of Ohio.184 The move was accompanied by the speedy removal of county records to the new location, and a strong protest and lawsuit on the part of the Umatilla Landing faction. But the deed was done, and Pendleton quickly grew as Umatilla declined. Meinig described the controversy as "the first of the many often chronic and bitter county seat rivalries, which would become prominent features of the evolving political geography of the [Inland Empire]." In 1874 the town of Weston began to agitate either to have the county seat moved there or have a new county created out of the northeast portion, with it, of course, as the new county seat, but the effort was unsuccessful. Gaining the county seat was a prize worth the effort, as Pendleton demonstrated by its dynamic growth. It was ideally situated at the intersection of wellestablished lines of communications, with good roads leading to

184 The naming of the new county seat was at the suggestion of County Judge G. W. Bailey in honor of George Hunt Pendleton, Democratic candidate for Vice-President in 1864, on the ticket with General George B. McClellan. Umatilla County was an overwhelmingly Democratic stronghold, and the senator was admired as a reformminded Democrat. McArthur, Oregon Geographic Names, 576. 
Walla Walla, La Grande, Umatilla Landing and the Columbia, The Dalles, and the new settlements up Birch and McKay creeks. ${ }^{185}$

\section{Surveys}

Obtaining accurate surveys and plat maps had been a vexing problem in Eastern Oregon. On 27 September 1850, Congress passed the Oregon Donation Land Claim Act, which granted land to settlers who were living in Oregon prior to the passage of the law. It led to the appointment of the first federal Surveyor-General for Oregon and provided for exact surveys of the Territory according to the geodetic method. The early surveying work concentrated on the Willamette Valley, to verify existing claims and to establish the legality of the new ones being made every day. Land east of the Cascades, with its paucity of white settlers, would have to wait. 186

By 1855 there were two United States Land Districts in Oregon: The Willamette and the Umpqua, with offices at Oregon City and Winchester. The Surveyor-General contracted for competent surveyors at set prices, who would then hire crews to complete the work. In 1855, Surveyor-General C. K. Gardiner had twelve parties in the field and hoped to extend surveys into the country east of the Cascades. He and his successor in 1856, John S. Zieber, reported numerous difficulties in hiring and keeping

185 Parsons, 139-142; Meinig, 234-235.

186 The Oregon Donation Land Claim Act granted up to 640 acres to married couples and 320 acres to single men on condition that they live on the land claimed for four years. 
helpers. In the first place, the lowland areas that were settled first were by then surveyed; the work in the Coast Range and Siskiyou Mountains was much more physically demanding. Indian hostilities created delays. Also, the pay demanded by helpers would push the cost over the agreed contract amount. Surveyor-General Zieber, in a 17 September 1856 report, stated:

The partial cessation of Indian hostilities, and, probably, early restoration of peace within our borders, may remove some of the causes which have heretofore prevented a reduction of those rates; but as these occur, others take their places. It is already found that, as in former years, the mines in the vicinity of Fort Colville, and especially those in Southern Oregon, as Indian hostilities abate, draw off laboring men from every county in the Territory. The most exciting reports of success in the gold mines abound, and operates greatly against the deputy surveyor in employing assistants, except at prices which are not warranted even by the apparently high government prices of surveying in Oregon. The assistant asks more than the contractor himself can rationally expect to clear; he abandons the field, and perhaps both prefer to take their chances in 'the diggings.'

The public lands which remain to be surveyed in Oregon are probably rougher than any that have ever been sectionized in the Territories of the United States. Scarcely an unsurveyed township of land can be found without canyons, ravines, or precipitous hills; and most of the unsurveyed territory abounds in heavy timber. . .

Believing that the proper period has arrived to authorize the extension of the Oregon surveying district east of the Cascade Mountains, I renew the recommendation to that effect found in the last annual report from this office. The lands lying between the Cascade and Blue mountains, and particularly those on 
the Des Chutes, John Day, and Umatilla, are valuable and desirable, especially for stock farming. At the Dalles of the Columbia a business town (Dalles) has sprung up; a number of enterprising settlers have taken claims, and made considerable improvements. Settlements had also been made before the war at Whitman's Station and on the Umatilla. These will be soon resumed and increased in number; and on the positive restoration of peace, emigrants will repair to other points on the banks of the Columbia and the above-named rivers. The surveys should precede the settlements. . .187

In his next annual report, Zieber reiterated these same points and recommendations, adding: "There are also considerable settlements and improvements on the Umatilla and Walla Walla rivers, where surveys are required. . "188 But problems and delays continued. The first United States Government Survey in Umatilla County did not take place until 1861, and included only a portion of the county. With the frenzied search for gold so close to Umatilla County, crews were hard to find and harder to keep. When the surveys were made, in several different installments, they barely kept up with settlement. It is possible to view on microfilm surveys of the same township plat done in different years and see the development of road systems over time. A few townships were surveyed in 1861 , then more in 1864,1867 , $1871,1874,1881,1885$, and 1890.189

187 Thomas W. Prosch, Notes From a Government Document on Oregon in the Fifties, OHQ Vol. 8, No. 2 (1907), 196-198.

188 Ibid., 199-200.

189 Microfilm of GLO Survey Plats for years indicated, Umatilla County, located in Bureau of Land Management office, Portland, Oregon. 
Survey plat maps showed Indian trails as a dotted line, but many of these trails undoubtedly eluded the detection of the surveyor. Indeed, the town of Helix, platted in 1880 and having a post office established that year, is not shown at all on township 4 north, range 33 east of the GLO plat book for May 1885. All that is shown on that page is the square section lines. The town of Thornhollow also turned up missing that year. ${ }^{190}$

\section{County Roads}

Under the General Laws of the State of Oregon, the county court had all authority over county roads, public bridges and ferries. The laws specify that any application for laying out, altering, locating, or vacating of a county road be done by petition to the county court, signed by at least twelve householders residing in the vicinity of that road. Proof must accompany the petition that certain requirements of public notification be made. At that time, the court would appoint a "skilful" surveyor and three disinterested householders of the county as viewers, and would order them to meet on or about a specified day to view, survey and lay out or alter the road.191

190 GLO platbook for Umatilla County, May 1885, J. H. Gerhard, surveyor, located in the Planning Office, Umatilla County Courthouse, Pendleton, Oregon. Thornhollow is also spelled "Thorn Hollow."

191 Matthew P. Deady, compiled and annotated, The Organic and Other General Laws of Oregon together with the National Constitution and Other Public Acts and Statutes of the United States, 1845-1864, (Portland: Henry L. Pittock, State Printer, 1866), Chap. 47, Title I, Sections 1-4. Hereafter cited as Oregon General Laws. 
The county surveyor had the responsibility to survey both private land claims and county roads. His survey was to be based on certified copies of the original Government survey and field notes. The lack of these plats and notes had little effect on early Umatilla County business regarding roads, since the first petitions were to designate already existing roads as being county roads. On 6 July 1864, the Court directed the clerk to "keep a separate Record from this Journal in which he shall Record all matter that may be directed by this Court appertaining to Roads."192 This record started with County Roads and Field Notes, Volume A, located in the Roadmaster's Office in Pendleton. In order to research a particular county road, there are three separate sets of records to review: first, the Commissioners' Journals, at the Courthouse; second, the County Roads and Field Notes in the Roadmaster's office; third, the case files which include the actual petitions, correspondence, and miscellaneous material, in the Roadmaster's office.

The most useful information is contained in the Commissioner's Journals, although actions on county roads are intermixed with other court business, such as issuance of liquor licenses, care of the indigent, appointment of jurors, and other routine business. The first entries regarding county roads in Umatilla County are reproduced in full here as Appendices A, B,

192 Commissioners' Journal A, 52. 
and C. Appendix $\mathrm{C}$ is a clear and well-written example of the format used by viewers to report the results of road surveys. It sets forth the methods to be used to mount surveys and report their results, as required by State law. Also, taken together, Appendices $\mathrm{A}, \mathrm{B}$, and $\mathrm{C}$ record the historical significance of proposing a county road through the Umatilla Indian Reservation, as detailed later in this chapter. The petition was granted on 6 September 1866 and the route from Umatilla City via McKay Creek to the summit of the Blue Mountains was designated as County Road \#1.193 (See Appendix D, Map 2.)

The surveyor and the viewers, after administering among themselves oaths to faithfully discharge their duties, employed two chain bearers and one marker, and proceeded to the location of the road to be considered. After the survey, they made a recommendation to the court based on their opinion of the expense, utility, and convenience of the proposed road. The route was marked by tree blaze, stone, stake, or mound of compacted earth, and each mile specifically designated. The surveyor prepared a certified plat and survey with field notes for one of the viewers, who would forward it with a written recommendation signed by all the viewers to the court clerk. The report was read in court and, if there were no more remonstrators

193 County Roads and Field Notes, Vol. A, entry for 6 September 1866. Hereafter cited as County Roads, page and date, if available. Commissioners' Journal A, 148-149, 241-242. 
than petitioners, the court would cause the petition, recommendation, and any related material to be recorded, after which it was considered a public highway, and the court would officially order it to be opened. If a viewer refused or neglected his duty, a fine of up to ten dollars could be imposed. The petitioners were required to post a $\$ 200$ bond with their petition. 194

County funds for road maintenance were scarce.

Maintenance and repair of county roads was accomplished by requiring free labor of those landowners adjacent to the roads.

Counties in Oregon were divided into numbered road districts, and during the February terms their commissioners appointed a supervisor of roads for each district. When the court received a petition for designation of a county road, the court clerk provided a list of the petitioners to the road district supervisor, who required one day's labor of each in opening the road. In other words, before any county road was designated and opened, the petitioners, under the direction of the district road supervisor, performed such work as was necessary to make it fit for travel by the general public. Any petitioner could pay two dollars per day to the supervisor in lieu of each day's work, the money to be expended in hiring labor to complete the work. ${ }^{195}$

\footnotetext{
194 Oregon General Laws, Chap. 47, Title I, Sec. 5, 13, 14 . By 1893 the bond was raised to $\$ 400$.

195 Oregon General Laws, Chap. 47, Title I, Sec. 18, 19, 20.
} 
The system for routine maintenance of county roads required the road supervisor to submit to the county clerk a list of all persons residing in his district who were fit to perform labor on public roads. The clerk affixed to each name the amount of taxable real property, and the supervisor then apportioned the labor to be performed based on the ratio of one day's work for each two thousand dollars assessed valuation. On 24 October 1866 the law was amended to decrease the amount of assessed valuation to equal one day's work to one thousand dollars, an indication of the increase in wear and tear on the roads and the need for more labor to keep the roads in good order. Males between the age of twenty-one and fifty who did not own property were assessed two days' work. Work could be commuted at the rate of two dollars per day. Any who refused the order of the road supervisor, or "pass[ed] his time in idleness or inattention" could be fined by the court. The supervisor had the discretion to order any person to furnish a team of horses, mules or oxen, with scraper or other such implement, in lieu of any labor due from that person. 196

The wear of heavy traffic and seasonal weather on county roads kept the road supervisors and their crews busy. They pried out protruding rocks, removed fallen timber, filled in ruts and

196 Oregon General Laws, Chap. 47, Title I, Sec. 21, 22, 24, 26; Oregon General Laws, 1843-1872, (Eugene Semple, State Printer, 1874), Chap. 50, Title I, Sec. 22. 
potholes, and leveled the road. In addition to the obvious benefit that all would enjoy from good roads, the landowners wanted to avoid any liability for damage to passing stagecoaches or freight wagons. Anyone who had themselves or their goods bounced off the vehicle, if they were looking for someone to blame, would be directed to the courthouse in Pendleton. Without the county road designation, the landowner could be held responsible. Also, a county road designation would preclude anyone from installing a gate and charging a toll without license.

It was the responsibility of the district road supervisor to keep the roads open and in good repair. In a survey of the Commissioners' Journals, only one entry was found that indicated dissatisfaction with any district road supervisors. On 10 July 1883, the Court found that a rural county road had been obstructed by fences at three points. ". . .the Court has heretofore appointed two road supervisors of said road district [who] have failed and neglected to qualify as such. . ."; the County Sheriff was ordered to proceed and remove those obstructions that had impeded traffic on a public road. An entry for 7 August 1884 was also out of the ordinary. Sworn viewers failed to appear and were ordered to show cause why they should not be cited for contempt. Normally, a sense of civic duty if not a fear of notoriety provided sufficient motivation to perform the duty. 197

197 Commissioners' Journal F, 10 July 1883, 7 August 1884. 
The importance of road business in the Umatilla County Court is indicated by the fact that the East Oregonian published all court actions involving roads. The court evidently attempted to organize its calendar of business so that all petitions, recommendations, and other actions involving roads would be dispensed with by the spring of each year. In 1884, April was the busy month. On the 15 th, fifteen different sections of county roads were acted on. On the 18th, seven new road supervisors were appointed, and six new road districts were established. On the 25 th, nineteen more road sections were acted on. It should be noted that the East Oregonian was a bi-weekly newspaper; the dates indicated here are the dates of that issue of the paper; the date of the actual court action could have been a day or two earlier.

The next year, 1885, the court conducted road business earlier in the year. On the 27th and 28th of January, routine road business was dispatched, with two of the petitions denied for technical reasons. The petition involving road \#214 was denied "on account of survey not corresponding with description in petition;" the petition on road \#239 was "denied because affidavit does not prove posting of notices full thirty days." In a very unusual action, according to the East Oregonian, a woman, Mrs. Paulina Dunstan, was appointed as road supervisor and allotted $\$ 52$ for expenses. But the report was erroneous. Her husband, John, had died and she had simply submitted the required report 
and request for reimbursement for $\$ 52.20$ in labor and expenses due the deceased.198

The early laws added an additional responsibility regarding noxious weed control, which the Umatilla County Court passed along to the district road supervisors. These men were delegated the responsibility to discover any of these weeds and, using the labor provided for by law for maintenance, exterminate them before they went to seed. Compensations and penalties were the same as for normal road maintenance. On 9 June 1894, the Commissioners' Journal recorded an entry that, as there were Canada thistles in Road District \#21, the law required the appointment of a "Thistle Commissioner"; William Coffman was a suitable man for this position and M. T. Allen was also qualified for the same responsibility in District 47 . It is not clear whether these men were also the road supervisors for their districts, or whether this was a specific delegation only to eradicate the thistles. 199

Supervisors were required to account for any money received and days worked by district residents; they were required to turn over to successors any records or money in their

198 East Oregonian, 28 January 1885; Commissioners' Journal F, 700, 24 January 1885.

199 Oregon Laws Showing All the Laws of a General Nature in Force in the State of Oregon including the Special Session of 1920, compiled and annotated by Hon. Conrad Patrick Olson, Code Commissioner, Vol. II (San Franscisco: The Bancroft Whitney Co., 1920), Chap. 34, Sec. 4838, 4846, 4847; Commissioners' Journal F, 9 June 1894. 
possession. For these many responsibilities, the supervisor received two dollars per day from the county treasury for those days in excess of those required of any resident under the law. Surveyors received three dollars per day; viewers, chain carriers and markers two dollars per day. The Umatilla County Court examined requests for payment and reimbursement closely. In one entry, on 10 July 1883, the Court disallowed mileage for chainmen from Pendleton to travel a substantial distance, and chastised the surveyor, who should have employed men from the vicinity of the affected road. By 1893, the Umatilla County Court had designated seventy-one road districts. 200

In Umatilla County, there was a flurry of activity from petitioners to designate as county roads those thoroughfares that fronted or passed through their property. Many petitions were worded like the one for the old Lincton Mountain Road:

...[F]or the following reason viz. That it is already a leading thoroughfare between the valley of Walla Walla and the country South East of the Blue Mountains, that it is a good natural location for a road, the grades being generally easy, and that it is much needed as a road to have timber from the mountains into the valley. 201

It was designated County Road \#11. The road from Umatilla to Pendleton along the Umatilla River was designated \#6, after the

200 Oregon General Laws, Chap. 47, Title I, Sec. 33, 36; Journal F, 58, 10 July 1883; "Arnold's Official Map of Umatilla County, compiled by John C. Arnold, County Surveyor, W. M. Pierce, County Clerk, 1893."

201 County Roads, Vol. A, 17. 
Court received a similarly worded viewers' recommendation. Both were old Indian trails. 202

State law authorized corporations to be organized for the purpose of constructing private toll roads, like the Thomas and Ruckels Road. Provisions were made for acquiring public or private lands on the proposed route. Streams had to be bridged or ferries provided in a safe and acceptable manner. They were considered a common highway, with the requirement to keep them in good repair. Those exempted from paying tolls were public officers on urgent business, post riders, couriers, physicians, surgeons and midwives. These individuals were also exempted from paying any tolls on any public road, bridge, or ferry. The law provided that after ten years of taking tolls, the road would be purchased by the county. If mutually acceptable, the county could purchase the road at any time prior to the expiration of the ten year period. 203

State law delegated to the counties the authority to grant licenses to persons to keep ferries for terms not to exceed five years. The fee was not to exceed $\$ 100$ per annum, and would be paid for one year in advance to the county treasurer. The ferry operator was required to be the landowner of at least one of the landings. He was required to provide a bond in the amount of from $\$ 100$ to $\$ 500$. He was also required to keep his ferry in

202 County Roads, Vol. A, 16.

203 Oregon General Laws, Chap. 8, Title II, Sec. 23, 24, 26, 30, 31, 32. 
complete repair and safe running order. Every ferry was required to operate "from daylight in the morning until dark in the evening of each day," and any hour in the night on the payment of double the rate of ferriage. The county courts were authorized to set the rates, which were to be posted in a conspicuous and legible place at each landing. The law required that all persons be received into the ferry boats in the order of their arrival at the crossing point, except those who were exempted from paying tolls. They could go first, if on urgent business. 204

The Umatilla County Court licensed several ferries that had previously operated under Wasco County licenses. On 6 April 1864, F. P. Foster and D. A. Clifford were granted a license for a ferry across the Columbia from Umatilla Landing to Plymouth on the Washington side for a fee of $\$ 8$ per quarter. On 5 April 1867, N. B. Evans received a license to "keep a ferry across the Umatilla river at his old ferry" just above present-day Stanfield. Also on that day, John Bradburn was granted a license to keep a ferry at the crossing of The Dalles-Walla Walla Road over the Umatilla River, near Echo. A ferry also operated from Wallula across the Columbia under license from the Washington Territory.205

State law permitted counties to lease out public roads under certain conditions. If the road was located in a remote part of the

204 Oregon General Laws, Chap. 47, Title II, Sec. 40, 41, 42, 44-49.

205 Commissioners' Journal A, 27; Journal B, 105, 107: Robert H. Ruby and John A. Brown, Ferryboats on the Columbia, including Bridges and Dams, (Seattle: Superior Publishing Co., 1974), 71. 
county, and little or no local labor was available for maintenance, the county court could lease such a road, for a period not to exceed ten years, with the right to collect tolls. The leasee was required to repair and maintain the road in good order, taking the expenses from his toll receipts. A $\$ 2,000$ bond was required. Tolls were to be collected at a gate where a sign would be posted with the rates of toll plainly listed. Those excepted from tolls included those passing on foot, persons "travelling from one portion of his farm to another, with or without any stock or vehicle, or in going to, or returning from church, a funeral or an election." 206

On 9 October 1888, the Umatilla County Court offered a lease on a county road for five years with the right to collect tolls due to the lack of labor in the area to maintain the road, located in the extreme southern portion of the county. However, tolls were to be collected only on bands of loose stock. Bids were to be accepted until 3 December 1888 , but no notation was found in the Commissioner's Journal indicating if a lease was actually executed. 207

Private toll bridges were licensed in much the same manner as ferries. Licenses to operate toll bridges were granted in 1865 to John Courtney and Jesse Lurchin for the Lower Umatilla Bridge, to Mitchell and Richards for the bridge at Middleton for a fee of

206 Oregon General Laws, Chap. 47, Title III, Sec. 54, 56, 59, 60, 62.

207 Commissioners' Journal H, 144, 9 October 1888. 
$\$ 50$ for one year, to Moses E. Goodwin for a bridge across the Umatilla River in present-day Pendleton. In 1866 a license was granted to B. W. Parks for a bridge across Butter Creek for a fee of $\$ 10$. The court set the tolls as follows: man and horse $25 \phi$, wagon and span $75 \phi$, each additional span or yoke $25 \phi$, pack animal $12 \not$, loose stock $4 \phi$, and a footman $12 \phi$. Bids were sought and contracts let for the building of county bridges, but the successful bidder had no guarantee of profit. Mrs. Abbie Mays recalled that her husband and his partner had the contract for a county bridge, but "[t]hey. . . lost so much money on it that my husband sold his shop on Vincent Street" in Pendleton. 208

By the mid-1870s, it was not unusual to have petitions disapproved or for petitions to be filed to vacate the designation of a county road. As a sampling of county activity regarding roads, Commissioners' Journal D, July 1876 to April 1880, indicates:

Petition for Designation

Approved Denied

32 7

Petition for Vacation

Approved

5
Denied 1

\footnotetext{
208 Commissioners' Journal A, 85-86, 97, 240; Reminiscences, Abbie Mays,
} 138 . 
The denial of designations occurred when there was either a cloud on the land title, or simply too much dispute between supporters or opponents. The vacations occurred when a new route had been established and the land owner wished to fence off or otherwise stop through traffic on his property. Many petitions from owners of more open, treeless range land sought to alter the roads from the old trail routes based on Indian usage to new, more precise routes that were squared off to follow section and township surveyors' lines. This allowed them to keep livestock and human traffic out of their grain fields, but still allow traffic to move toward the destination. Many an ancient Indian path, along with long sections of the Oregon Trail, have since been plowed under fields of grain as a result. ${ }^{209}$

By 1889 , there were pre-printed forms for the petitioners to use and many records were typewritten in place of pen-and-ink entries. As time went on, petitions requested county road designations for smaller and smaller sections of road. Many were short extensions of long-used roads. Later plat maps show an intricate web of roads to support the growing population of Umatilla County. 210

209 Commissioners' Journals D, E, and F. For example, one of the major Indian trails, between Wallula and Cayuse on the reservation, has long since been plowed under the miles of wheat fields.

Reminiscences, D. H. Mansfield, 71.

210 Commissioners' Journals $\mathrm{H}$ and $\mathrm{I}$. 
Umatilla County Roads on Reservation Land (See Appendix D, Map 2.)

Three government-sanctioned roads passed through the Umatilla Indian Reservation - from north to south, the Thomas and Ruckel Road, the Oregon Trail, and the Hall Trail Road. Also, the Indian Service Road passed just to the south of the Reservation. An examination of these roads provides an understanding of the relationship between the Indians and the settlers as represented by their government agencies. ${ }^{211}$

Thomas and Ruckel Road. This road had originally passed north of the reservation, but through a very difficult terrain. Thomas and Ruckel wished to build a more southerly route that crossed the far northeast corner of the reservation. Permission had to be secured from the Indian Service to operate over and improve the road. Responding to the application from the Thomas and Ruckel Line, Commissioner of Indian Affairs D. N. Cooley sent a telegram dated 2 April 1866 to the Superintendent of Indian Affairs in Oregon, J. W. Perit Huntington 212 :

Permit Thomas \& Ruckel to cross Umatilla Reservation with U. S. mails, if not incompatible with the interests of

211 Gerald J. Tucker, unpublished manuscript, Pioneer Roads of The Blue Mountains, 1962, Penrose Library, Whitman College, Walla Walla, Washington. Hereafter cited as Tucker manuscript. This manuscript includes exact transcriptions of the government documents regarding these roads obtained from the National Archives, "Records of the Office of Indian Affairs, Oregon Superintendency."

212 Tucker manuscript, 69. 
the Indian Service. You are authorized to visit Washington if official duties will admit.

Huntington responded by a letter to Cooley dated 6 April 1866213:

Your telegraphic dispatch concerning permission to Thomas and Ruckel to carry U.S. Mail across Umatilla Reservation, and other matters. . .was forwarded to me at this place. I have this day given Agent Barnhart instructions concerning the matter, and transmitted the instructions of the dispatch to Thomas \& Ruckel. A copy of my instructions to Agent Barnhart is herewith enclosed, and I ask your attention to the same, and that you advise me whether the instructions therein given for the guidance of Barnhart are in accordance with the design of the Indian Service in making the order.

If it is permitted that individuals or counties shall lay out roads through (or interfering with) the improvements of the Indians, much dissatisfaction and difficulty will arise.

Instructions of similar sense were sent to Agent Barnhart upon receipt of your letter of December 18th, 1865 , authorizing the location of a county road through the reservation by way of Howtome or Birch Creek. But the question will arise, whether after the location of a road in legal form, under the sanction of your office, the County Authority will not have the right to open the same, whether it interferes with the farms and dwellings of the Indians or not.

I anticipate these questions, because when they do arise in practice, they will require prompt decision and action.

The reference in the third paragraph to a county road is to the Hall Trail Branch Road. Huntington's instructions of 6 April

\footnotetext{
213 Tucker manuscript, 69.
} 
1866214 to Agent William H. Barnhart clearly indicate the concern that further travel through the reservation will lead to conflict:

I have received a telegraphic dispatch from the Commissioner of Indian Affairs, directing that Thomas and Ruckel be permitted to cross the Umatilla Reservation with the U.S. Mail, if not incompatible with the Indian Service.

You are directed, upon receipt of this, to confer with Thomas and Ruckel and ascertain from them where they desire to cross the Reservation. If it appears that the route they desire to travel will interfere with, or pass through, any of the farms, buildings or other improvements upon the reservation whether belonging to the Government or to the Indians, the permission will in no case be granted. But if on the contrary it appears that the route proposed by them will not interfere with or damage the Government or the Indians, upon your report to that effect made to me at Salem, I will issue license to them with the grant contemplated. It will be necessary to define the route in issuing the license, and I must rely upon your report for such data as will enable me to describe it with sufficient exactness. You will endevour [sic] therefor to make your report full in that particular, as well as in others, making it such as will enable me to understand the whole matter.

I should also add in this connection, that the license, if issued, will Extend merely to the right to travel across the Reservation, and cannot be permitted to be used as a means to establish trading posts, towns or to make locations with a view to claiming the land. It will also be conditional that, if Thomas and Ruckel, or any person in their Employ, introduce any ardent spirits among the Indians, or attempt to interfere with the jurisdiction of the Agent over the Indians, the license will instantly be revoked.

214 Tucker manuscript, 70. 
Cooley replied by letter dated 19 May 1866 to Huntington approving the instructions given to Agent Barnhart. On 6 October 1866 Barnhart forwarded to Huntington the application and bond of Thomas and Ruckel, accompanied by a diagram of the proposed route. The work on the road was completed and it was opened for travel in 1868. The U. S. Mail carried by the Thomas and Ruckel stagecoaches was accompanied by passengers and express. 215

The Oregon Trail. In spite of the provisions of the Treaty of 1855, there is no indication that any federal, state, or county government agency attempted to restrict traffic over the Oregon Trail. Westbound immigrants continued to come over the Blue Mountains in long wagon trains and cut through the heart of the reservation with their herds of livestock. With the pressure from the miners, packers, and freighters, there was no chance that the major line of communications would be closed down.

The first telegraph line across the Blue Mountains was built along much of the Oregon Trail to Telephone Ridge, then north to Thornhollow on the Umatilla River. The line was completed to that point in the fall of 1875 by the Nevada and Northern Telegraph Company. This added even more permanence to this highway through the reservation.

The Hall Trail Branch of the Oregon Trail. This trail was based on an Indian trail, as were the other major routes over the 
Blue Mountains. Apparently, some white men had begun work to open the trail for wagon traffic without any permission. Indian Agent Barnhart wrote Superintendent J. W. P. Huntington on 1 December 1864 of the problem 216 :

It being reported to me by Indians that certain white men were engaged cutting timber, building a public road and bridge on the Reservation, I served upon them a written notice requesting them to desist from the work and thereby perhaps save themselves further trouble. I am satisfied from evidence of the Indians, who are greatly excited about the matter, that the parties intend in proceeding with the work regardless of me, or any other authority. I do not wish to proceed to extremities unless compelled to do so, and I have therefor respectfully to ask for special instructions from you in regard to this affair. .

As there is one road open through the Reservation, and one directly on each side of it, the public necessity of another highway through the Reserve is not apparent to any one excepting the parties interested in building it. It is designed to make this road parallel with and a few miles to the southward of the road now traveled through the Indian lands [Oregon Trail], passing directly over several Indian farms on the bottoms of the Howtome (McKay) Creek. It is I am informed, being built as an opposition toll road from LaGrande over the mountains and is doubtless mainly a work of speculation by a few individuals.

Barnhart wrote to Huntington again regarding the road in a letter dated 15 February $1865^{217}$ :

216 Tucker manuscript, 31. Tucker spelled this route as the "Hall Trail" while in the Report of Viewers (Appendix C) it is spelled "Hull Trail."

217 Tucker manuscript, 31. 
Quite a number of emigrants of last year are on the borders of the Reserve, unpossessed of farms, homes, or apparently anything but a desire to take up lands upon the Indian Reserve. These people newly arrived in our State appear utterly oblivious to the fact that Indians have any rights whatever, and unless steps are taken to prevent it, a collision between them and the Indians is probable.

Several roads are being 'engineered' across the Reservation and only the presence of a military force upon the spot will prevent these roads from being consummated which, if not prevented, will certainly cause trouble if not bloodshed.

It is apparent that the white men involved went around the Indian Agent to the Umatilla County Court with a petition to open the Hall Trail as a county road. The court, in turn, lost no time in requesting the intercession of James W. Nesmith, U. S. Senator from Oregon, by sending him a signed and sealed copy of the resolution dated 9 September 1865, reproduced here as Appendix A. 218 On 8 December 1865, Senator Nesmith wrote to Commissioner Cooley asking for favorable consideration of the petition. Authorization for construction of the road was given on 18 December. ${ }^{219}$ The court ordered that the road be surveyed (see Appendix B) ${ }^{220}$, which was completed the next spring, and the report of the viewers (see Appendix C) 221 was filed during the

\footnotetext{
218 Commissioners' Journal A, 148-149.

219 Tucker manuscript, 32.

220 Commissioners' Journal A, 241-242.

221 County Roads, Vol. A, 2-4.
} 
April 1866 term. The road was designated County Road \#1 and ordered opened effective 6 September 1866.222

The Hall Trail Branch Road was specifically designed as a freighting road and, according to Tucker, "carried the bulk of the freight from Umatilla Landing across the Blue Mountains. . .from 1866 to $1884 . " 223$ In contrast to the immigrants using the Oregon Trail, the packers and teamsters on the Hall Branch were less inclined to record their travels in diaries or journals, and for this reason, no first-hand accounts of the use of this road have been identified. Also, since no stage stations or other settlements were permitted along its route, the public would be less aware of its existence. The Indians, on the other hand, would be all too aware of its existence, which could only have added to the many grievances that led to the widespread hostilities of the late 1870s.

The Indian Service Road. This road, also known, inaccurately, as the Pilot Rock Emigrant Road, or the Government Road, was constructed as a result of the requirement of Article 5 of the Treaty of 1855 . It took six years for any action to be taken to construct this road south of the reservation. William H. Rector, Superintendent for Indian Affairs for Oregon, wrote a letter dated 10 August 1861 to Henry G. Thornton of Portland, Oregon, regarding Thornton's appointment as "Superintending Agent" for the "locating and opening of a wagon road from Powder River or

222 Commissioners' Journal B, 6 September 1866.

223 Tucker manuscript, 33. 
Grand Round to the plain at the Western Base of the Blue

Mountains South of the Southern limits of the Reservation."

Thornton was directed to begin work immediately, with the following instructions 224 :

Before you expend any work on the road you are instructed to confer with the Agent in Charge, Geo. H. Abbott, also Mrs. Daniel Steuart, and such other citizens of the Umatilla Valley in the vicinity of the proposed road, as have explored the Mountains, and are abundantly qualified to give you such information as will enable you to locate the road on the most practicable route. You will bear in mind that it is stipulated by treaty that the road shall be located and opened South of the Southern limits of said Reservation. You will therefor cause no portion of the road to be located on the Reserve. By reference to the Treaty under which this road is to be opened (a copy of which will accompany these instructions) you will see the southern boundary of this Reservation clearly defined. You will, therefor, after a thorough examination of the route or routes as proposed by those to whom you have been referred, proceed to locate the same by marks or blazes on each side of the road. You will commence opening the road from the western terminus. In selecting your employees I would recommend you to give preference to the citizens of the Umatilla Valley, who are personally interested in the work, and to Emigrants who desire employment.

To the latter class I would call your special attention, giving them employment in all cases, provided you have subsistence and tools sufficient, even though the number exceed that to which you have been restricted.

You will continue operations as long as the season will permit.

224 Tucker manuscript, 43-44; Irene Barklow, From Trails to Rails - The Post Offices, Stage Stops and Wagon Roads of Union County, Oregon, (Enterprise, OR: Enchantments Publishing of Oregon, 1987), 19. 
Thornton must have received this letter immediately; he sent a letter dated 15 August 1861 from The Dalles reporting on his preparations to that point. Indian Agent William Barnhart wrote to Superintendent Rector on 5 August 1862:

The thoroughfare to the gold mines of Powder river and Granite creek passes immediately through the reservation, not less than four thousand persons having passed directly by the agency during the last four months. ${ }^{225}$ The influx of this great travel backward and forward through the reservation has had, and is having, an evil influence on the minds of the Indians. They imagine their lands will soon be stolen and themselves driven away. ..226

Thornton only had responsibility for the portion of the road over the Blue Mountains to the Grande Ronde Valley. Thornton submitted his report dated 20 November 1861 to W. H. Rector claiming: "The new road as located and opened from the western base of the mountains to Grand Round River, is far superior in every point to the old road." He calculated its length at forty-six miles with slopes less steep than the old road. One of its best features was its proximity to good water. 227

225 It can be assumed that most of this heavy traffic was not westbound immigrants, but those bound for the mining districts. The immigrants would begin crossing Umatilla County in the late summer and on into the fall, which could only have added to the vexation of the Indians.

226 Annual Report of United States Indian Agent William H. Barnhart, 5 August 1862, Document No. 56, in Senate Executive Documents, 37th Congress, 3d Session, Vol. II, "Report of the Secretary of the Interior", 1862, 414.

227 Report of Thornton to W. H. Rector dated 20 November 1861, published in The Daily Oregonian, 6 February 1862. 
The contractor who finished the eastern portion of the road to Powder River was Mr. B. F. Rector, not to be confused with Superintendent William $\mathrm{H}$. Rector, who died sometime between August 1862 and May 1864. He was replaced by Superintendent of Indian Affairs for Oregon J. W. P. Huntington, who in a letter of 28 May 1864 instructed the Chief Clerk in his office, C. S. Woodworth, to make a trip over the newly completed road and recommend "the proper amount of payment that should be made to settle this account. . ."228

Woodworth submitted a detailed report, dated 15 June 1864 , with the total recommended payment of $\$ 2,280$ to B. F. Rector for the portion of the road he had constructed. Apparently, some negotiations took place, because Superintendent Huntington offered Rector $\$ 4,140$ in settlement of the contract. Rector accepted the offer. No record has been located to document payment to Thornton. Woodworth noted in his report that the road had been in use since 1862 and had seen a "large amount of travel to and from the different Mining districts. . .229

No provision was made for maintenance of the Indian Service Road, as had existed for county roads, and it rapidly fell into disrepair. When the Daley Road opened as a toll road in 1864, much of the freight traffic diverted to it, but pack trains continued to use the Indian Service Road since no toll was 
charged. Most importantly to the Indians, the Old Immigrant Road/Oregon Trail continued to be the road of preference for westering pioneers. One immigrant diarist whose party traveled up the Grande Ronde River portion of the Indian Service Road in 1862 wrote:

Oct. 14th, 15th \& 16th, Crossing the Blue Mts. We have crossed the G R River about 20 times now. One day passed about 200 freight wagons for Auburn Mines coming from the Dalles; distance 250 miles. Later passed some 20 pack trains bound for Auburn mines; each animal having about $250 \mathrm{lbs}$ of freight. on his back. Weather bitter cold.

Oct. 19th . . .Passed large number of freight wagons for the Auburn Mines, some having as high as 7,500 lbs on one wagon to eight yoke of cattle. ${ }^{230}$

The Indian Service Road failed completely in meeting the requirement of Article 5 of the Treaty of 1855 to move the traffic off the Oregon Trail to a route south of the reservation. The tremendous pressure of the men heading for the gold mining sites could not have been anticipated, but the lack of any provision for routine maintenance precluded it from becoming an important part of the regional transportation system. In the meantime, traffic over the Oregon Trail continued unabated. Place of Transportation in Umatilla County

Many of the early community leaders in Umatilla County had been involved in some aspect of transportation. Lot

230 Henry R. Herr, Diary, 1862 (typed), Mss 1508, Oregon Historical Society, Portland, Oregon. 
Livermore had been mayor and councilman of Pendleton, but earlier in his active working life, he had been the Wells Fargo Express Agent in Umatilla Landing. Before his responsibilities as city councilman and on the school board, Jerry Despain operated pack trains to the Idaho mining regions. E. E. Sharon, once county surveyor, had been agent for the Northern Pacific Express Company. Judge Norborne Berkeley was first employed in Umatilla County in a forwarding and commission business. Abram Miller, pioneer justice of the peace for Alta precinct, as a young man hauled freight by six horse wagon teams. Civic leaders understood the importance of transportation to any economic endeavor; and rural residents, by their involvement within road districts, understood the practical considerations of maintaining systems of transportation. 231

Social Travel

Citizens of Umatilla County were very mobile. With nearly everyone owning or using horses, they moved about freely and were very aware of the importance of good transportation. With mobility, they could engage in active social interchange. Dances were very popular, attended by whole families. John E. Bean remembered that in Umatilla Landing the Masons' and Odd

231 Reminiscences, Mrs. Flora Berkeley, 96-98; E. E. Sharon, 175; Norborne Berkeley, 239; Abram Miller, 188. Also see Parsons, 333-500, for biographical sketches of these and many more early settlers of Umatilla county. 
Fellows'232 dances on holidays were the great social events of the year. "People would come from all over the country as far away as Pendleton, 60 miles, generally riding horseback." Mrs. Kate Frazier recalled being invited to a dance three months in advance by her future husband, Frank:

"The beau with whom I was going to the dance was tending sheep, so the night of the party he walked eight miles to a ranch to get a horse, then rode eight miles to town; danced all night, rode horseback to the ranch and then walked eight miles to where the sheep were grazing."

Ad Nye recalled that all those who lived along a seven or eight mile section of the Umatilla River from Barnhart Station to the Jack Morton farm got together every Thursday night for a dance. That section became known as "Happy Canyon." Mrs. Ellen Bowman Stover recalled riding to dances, sometimes two on a horse: "Twenty or thirty miles was no great distance to go to attend a dance." 233

Camp meetings were frequently announced in the East Oregonian, and, as Mrs. Lee Moorhouse wrote, they were attended by "those whose religious scruples did not allow them to go to dances." Families would go to Sunday church services by horse or wagon, even if the distances involved would make it an all-day

232 Fraternal organizations were very popular in Umatilla County. It was not unusual for a man to belong to several.

233 Reminiscences, John Bean, 69; Kate Frazier, 151; Ad Nye, 86-87; Ellen Bowman Stover, 183. 
journey. Mrs. A. H. Rugg's family made the seven mile trip from their ranch to the Methodist Church in Pilot Rock.234

A social life required significant effort, as Clara Stocker well remembered:

The sociability and neighborliness of those early times were characteristic of the west. Neighbors were few and scattered, transportation was difficult, so when the opportunity came for a visit, we made the most of it.235

D. H. Mansfield recalled: "When people went visiting it wasn't just for a few hours; we used to stay all night or as long as two or three days."236 Neighbors would ride into Swift's Station to pick up each other's mail. Neighbors came together for spelling bees, community sings, amateur theatricals, picnics, and horse races. Local Commercial Travel

As Umatilla County became more and more settled, local commercial traffic developed as the population increased. The East Oregonian, always a business booster, carried frequent announcements that indicated that traffic on the expanding road system was busy. Some items from the East Oregonian will give an indication of the traffic:

Lot Livermore has purchased a neat light spring wagon No. 56 and will shortly start on a journey through the county selling the Singer sewing machine.

234 Weekly East Oregonian, 16 June 1877; Reminiscences, Mrs. Lee Moorhouse, 25; 179-180.

235 Reminiscences, Clara Stocker, 41.

236 Reminiscences, D. H. Mansfield, 72. 
An ox team consisting of five yoke is now engaged in hauling pine and fir wood from the mountains. $\$ 5$ a cord is asked.

Thomas Benson traveled a meat sales route from Echo to Umatilla Landing. The East Oregonian routinely carried advertisements from Pendleton hotels and restaurants that catered to commercial travelers. Traveling salesmen, called "drummers," were frequently seen on the roads driving their own horse and wagon outfit. Hotels and restaurants would reserve a "drummer's table" for the commercial travelers. 237

The Commercial Club of Pendleton, the forerunner of the Chamber of Commerce, was very active at the turn of the century in community development. Formed in February 1893, the impact of this organization on transportation in Umatilla County is recorded by Parsons:

The project of good roads throughout the county has always received the hearty support of the association. It has spent much money in improving the thoroughfares between Pendleton and Pilot Rock; with the assistance of the Indian agent it virtually constructed the road to the reservation, and last year expended $\$ 400$ in improving this road; the road through Wild Horse Canyon toward Adams, was built by the Commercial Association; it was the moving power in causing the toll road between here and Grant county to be changed into a public road, its members contributing $\$ 400$ toward this project, and succeeding with the assistance of the county. In all, the

237 East Oregonian, 16 June and 11 August 1877; Reminiscences, Thomas Benson, 104; Oliver, 96 
Commercial Association has expended $\$ 2,000$ for the establishment and improvement of county roads.

The East Oregonian reviewed the many contributions of the Commercial Club to the betterment of roads in its 8 March 1889 edition. This activity in promoting good roads is a clear indication of the level of support and the importance accorded to transportation in Umatilla County. It is also important to note that these activities took place after the completion of rail connections, and during a period of serious national economic depression, indicating the continuing importance of roads within the transportation system. 238

Governmental, social, and commercial institutions were developed and integrated in their understanding of and support for an efficient system of transportation. The citizens of Umatilla County did not restrict themselves to their rural homesteads; they moved freely throughout the region for business and personal reasons, using horses as the regular means of conveyance. The requirement for all able-bodied men to work in support of the county road system gave them a clear and practical understanding of overland transportation. This support was important in a county that relied for economic prosperity on the movement of wheat, wool, and other agricultural commodities to market, particularly in anticipation of the coming of the railroad.

238 Parsons, 180-181; East Oregonian, 8 March 1889. 


\section{CHAPTER 9}

\section{FARM-TO-MARKET TRANSPORTATION AND THE IMPACT OF RAILROADS}

The first agricultural effort in Umatilla County began on the Hudson's Bay Company farm near present-day Umapine. It was located along the early road used by fur trapping brigades on the way from Fort Nez Perces to the Snake River Country and is referred to in the Commissioners' Journals and on plat maps. ${ }^{239}$ It was the Whitmans' settlement, however, that made the first distinct agricultural impact, as detailed in Chapter 4. In 1841, Dr. Whitman produced approximately 300 bushels of wheat. 240 Enough was produced to justify the construction and operation of a grist mill. But the arid climate convinced early visitors and settlers that only the riverine land would yield decent crops. When settlement of the Inland Empire finally began, those lowland areas, from The Dalles to Walla Walla, were quickly claimed.

The real beginning of market agriculture in Umatilla County began when these early settlers produced any crop or farm product in excess of their own needs. Settlers sold produce to miners or passing packers and freighters. Thomas Benson recalled the early efforts of his family:

239 Commissioners' Journal F, 60; Journal H, 710, 6 March 1891; Arnold's Map of Umatilla County, 1893.

240 Wilkes, Vol. IV, Chap. 11, 393-395. 
With the coming of spring, my father and William White, mother's brother, entered into a partnership and raised vegetables. There was a good market for them as we sold to freighters who passed our place on their way to inland points. . . What the freighters didn't buy we sold at Umatilla Landing, to the river trade. ${ }^{241}$

Excess farm produce was routinely bartered or sold. As settlements grew, markets grew also. But for any farmers to gain prosperity through markets either internal or external to Umatilla County, the transport of the produce had to be reliable and efficient. As this study has shown, the routes of both steam navigation and overland transportation had been developed over a long period of time. Even when travel became difficult due to the seasonal weather and wear on the roads, a system was in place to keep them open and goods moving. The question was whether this system was sufficient to handle the needs of a major agricultural region.

\section{Dryland Wheat Farming}

The first grain grown by settlers was for their own consumption and as feed for their livestock. As the cattle business grew in importance in the $1860 \mathrm{~s}$, the feed grains predominated. In 1864, Umatilla County produced 11,404 bushels of barley, 54,736 bushels of oats, 16,739 bushels of wheat, and 114 tons of hay. ${ }^{242}$ If one can assume that the oats and barley

241 Reminiscences, Thomas Benson, 103.

242 Inventory of County Archives of Oregon; No. 30 Umatilla County (Pendleton), The Oregon Historical Records Survey, Work Projects 
were not for human consumption, it is clear that most grain production began as crops for livestock feed. Whatever the grain crop raised, the straw was saved for feeding livestock during the winter when the snow covered the ground, often using sleds for delivery. The upland areas appeared too arid and sterile to be productive. As the lowland areas filled up, the upland areas were tested as grain-growing regions and it soon became apparent that they would produce excellent harvests without irrigation. If the land could support the nutritious bunchgrasses, it could support grain fields. 243

Converting an area of land that had produced native grasses for untold hundreds of years was no small undertaking. The fibrous roots of the bunchgrass formed a thick, dense sod that did not submit easily to a plow. C. A. Barrett recalled an early settler who planted corn by using an ax to cut a slit in the sod, dropping a kernel of corn by hand. Farmers of the day spoke of "breaking sod." 244

The use of the term "dryland farming" here is not intended to denote any particular scientific system of agronomy, such as the "Campbell system." It refers to the development of agriculture on arid land that relied on seasonal rainfall for irrigation and knowledge of the weather cycles to plant and Administration, January 1942, A-68.

243 C. A. Barrett, Early Farming in Umatilla County, OHQ Vol. 16 (1915), 343-349; Meinig, 223-224.

244 Barrett, 346, 349. 
harvest crops at the optimum times. Fortunately for the farmers of Umatilla County, the soils of the uplands were not only fertile, but also retained subsurface moisture very well. Many tens of thousands of acres of land were put into productive use without the benefit of irrigation. 245

Andrew Kilgore is considered the first man in Umatilla County to raise grain for a living. In 1864 he planted and harvested a crop of wheat near the point where Weston grew up. The grain was cut by hand, tramped out by horses, and taken to Isaac's mill in Walla Walla for grinding. The government mill on the Indian reservation was of too limited a capacity to grind more than small amounts of wheat for home use. By 1868 several more settlers planted wheat in the area, threshed by a small horsepower machine owned by William Courtney. ${ }^{246}$

Farmers began turning under the tough sod to plant wheat as a cash crop. The mines provided the first good market for flour, but by 1867 downriver shipments had begun. From 19 April to 2 June of that year 4,735 barrels of flour were shipped from Wallula. The Wallula correspondent for the Walla Walla Statesman reported: "The road from Walla Walla to Wallula is literally lined with heavy freight teams, eight or ten yoke of cattle and four, six, eight and ten mule teams, all heavily loaded with

\footnotetext{
245 Meinig, 411; for the development of a more scientific wheat culture in the Inland Empire, see Chapter 13.

246 Reminiscences, 98
} 
flour are coming in every day." The next year, the first vessel embarked from Portland for Liverpool, England with a full cargo of flour from the Walla Walla valley. The foundation of a global export agricultural economy based on wheat, along with that of wool as detailed in Chapter 7, was thus established.247

William S. Byers of Baden, Germany, built the first flour mill in Pendleton. His entrepreneurial energy did much to develop wheat farming in Umatilla County. He would drive a freight wagon as far as Weston to haul wheat for milling if the farmer was unable to do so. The energetic miller furnished new farmers with seed to get them started and at the same time generate his future business. 248

It took a tremendous effort to get the wheat from the fields to the mills. Teams of horses or mules worked the wheat farms. Many wonderful photographs exist of up to thirty-two horses or mules in one hitch, pulling a "combined harvester," appearing more like a herd than a team. The driver, perched ten feet above the backs of the animals on an elevated seat called a "pulpit," steered the fantastic assemblage by means of a single jerk line connected to the left-hand animal of the lead pair. Flat bed wagons, often of the Bain, Moline, or Studebaker brand, loaded with sacked wheat and hooked up five or six in a row, and hauled

\footnotetext{
247 Quoted in T. C. Elliott, The Dalles-Celilo Portage: Its History and Influence, OHQ Vol. 16 (June 1915), 169; Gilbert, 240; Meinig, 226.

248 Reminiscences, 153.
} 
by a sixteen-mule team, crowded the roads during harvest time. Wider wagons carried bulky wheat hay. On the country roads, fine powdery ankle-deep dust made hard work for animal and man. Mrs. M. J. Cronin wrote: "The dust was knee deep in summer and the mud knee deep in winter. . ." Animal traction was used to move a variety of farm equipment: plows, harrows, combines, drill seeders, cook wagons, and water tanks. Out on the roads, a farmer new to the county moved about frequently, visiting neighbors, borrowing tools, and hauling wood from the mountains. 249

Despite the early successes in wheat farming, its development was slowed by the difficulties of dryland farming and problems of transportation. Plowing the bunchgrass sod was arduous work and harvesting machinery was expensive and in short supply, as was labor. The cost of transportation to both bring in new settlers and carry out harvested grain was very expensive. Frank T. Gilbert wrote of the situation in 1867: "There was but little encouragement for farmers to produce much, for the rates of freight were so extremely high that grain could not be shipped with a profit." The settlement and productivity of the "Wheat Belt," stretching from Pendleton northeast to the Palouse

249 Umatilla County: A Backward Glance, 104, 102-103, 109, 110; Reminiscences, Mrs. M. J. Cronin, 203. 
Country, would depend to a very large degree on the advent of the railroad. 250

The last surge of human movement to and through Umatilla County in the nineteenth century was due to the "mini"-land rush to settle the grasslands. Settlers came from all directions in the late $1870 \mathrm{~s}$ and the $1880 \mathrm{~s}$, most heading toward the new agricultural promised land of the Palouse, a broad region of rolling hills northeast of Walla Walla. The population of the Palouse, estimated at around 1,000 in 1872 and 2,000 in 1876, grew to more than 7,000 in 1880 . Regular wagon trains came from west of the Cascades along The Dalles-Walla Walla Road, some having "Palouse or Bust" painted on the side. The East Oregonian noted in June 1877: "The passing of emigrant teams directly in front of the East Oregonian office from six to twenty a day has become so common that it ceases to draw the attention of the editor." In December of that year the editor wrote: "Immigrants are still pouring into the country, not a vacant house in Walla Walla, Milton, Weston or Pendleton and no lumber to build with."251

As had been the case so often in the past, Umatilla County was not the destination of many of the settlers. But as the Walla Walla River valley and the Palouse filled up, and as the agricultural prospects of the grasslands of Umatilla County became better known, claims were made and farms established to

250 Meinig, 241-242; Gilbert, 263.

251 Meinig, 245; East Oregonian, 16 June and 1 December 1877. 
complete the "Wheat Belt." This broad strip of fertile land began around Pendleton and reached northeast through Walla Walla, Waitsburg, Dayton, and Pomeroy. That left much of the upland grasslands between Pendleton and the Columbia River vacant. D. H. Mansfield of Athena wrote of that land in the 1870s: "It was a wild country and you could ride straight to the Columbia river without running into a single fence." The limitations of animal traction over long distances hindered the full settlement and productivity of much of the county. The deficiency was in transportation and the remedy was to be railroads. 252 The Coming of the Railroads (See Appendix D, Maps 4 and 5.) Dr. Dorsey S. Baker was an energetic and progressive businessman of Walla Walla who foresaw the importance of railroads to the Inland Empire. He determined for a number of reasons to construct a narrow-gauge railroad connecting Walla Walla and Wallula. Freight rates on the thirty-three mile wagon road were from $\$ 5$ to $\$ 6$ per ton, which was seen as extremely high for the distance involved. Dr. Baker also hoped that the railroad would help to encourage more settlement and wheat farming in the Walla Walla Valley, and thus contribute to the overall improvement of the business environment. He hoped and expected that when the Northern Pacific Railroad finally completed the transcontinental railroad, it would come through 
Walla Walla, thereby insuring the preeminence of that city in the Columbia Basin. And, finally, he hoped that the line would be profitable, which, when finally completed, it was. 253

Baker began surveying for the Walla Walla and Columbia River Railroad in 1871 and by 1874 only sixteen miles of wooden rails had been laid, to Touchet Station. But that was enough to begin the shipment of wheat from both the Oregon and Washington sides of the Walla Walla River valley. The rails wore out quickly, so Baker had them faced with strap iron. The next segment reached Waiilatpu, also known as Whitman Station, and then in 1875 the "strap iron railroad" was finally completed to Walla Walla. By that time the wooden rails were replaced with all steel rails. ${ }^{254}$

The following table 255 indicates the growth of freight shipped over the Walla Walla and Columbia River Railroad:

TABLE 4

\begin{tabular}{rrrrr} 
Year & Grain and Flour & \multicolumn{2}{c}{ Merchandise } \\
\cline { 3 - 5 } 1874 & 4,021 & tons & 1,126 & tons \\
1875 & 9,155 & tons & 2,192 & tons \\
1876 & 15,266 & tons & 4,036 & tons \\
1877 & 28,807 & tons & 8,368 & tons \\
1878 & 27,365 & tons & 10,454 & tons
\end{tabular}

253 W. W. Baker, The Building of the Walla Walla and Columbia River Railroad, The Washington Historical Quarterly Vol. 14 (January 1923), 3-5. The length of this line has been variously described as between 31 and 35 miles.

254 Baker, 6-13.

255 Based on Baker, 10. 
This short rail line certainly helped move produce from Walla Walla to the Columbia River, but the resultant increase in grain production only exacerbated the problems on the river. The carrying capacity of the few steamboats on the river was insufficient to accommodate a crop that was harvested and ready to ship within a short period of the year. Even when new boats were put into service, they could not keep up with the additional thousands of sacks of grain produced by the increasing number of wheat farmers. The figures above indicate that by 1877 the limit of the carrying capacity of the river transport system had been reached. A reporter described the situation in 1880:

To give an accurate idea of the trouble of transportation from Walla Walla to the ocean, we will follow a sack of wheat from the field where it is grown. It is hauled to the depot at Walla Walla and there stored, to await its turn when the twenty-five thousand tons already ahead are taken away. Then it is put upon the cars and taken to Wallula; then it is put upon the boat and taken to Umatilla and transferred to another boat for Celilo; then it goes through the warehouse to the cars, taken to The Dalles and stored again; then it goes by boat to the Upper Cascades, and is then delivered to the railroad, by which it is taken to the Lower Cascades and transferred to another boat, by which it is taken up the Willamette to Portland. Here again it is stored, and thence sent down the river to Astoria and the ocean. 256

Park Willis recalled another of the frustrations faced by wheat farmers of the region: 
There was no interstate commerce commission in those days and I remember hearing a great deal of complaint, not only about high freight rates but discrimination as well. When the wheat was brought to the depot and piled up, exposed to the weather, every farmer was naturally in a hurry to have his wheat shipped. Since there were not enough cars to handle the shipments, in addition to the ordinary freight charge, another higher rate was made which was called "fast freight." If Tom Jones brought his wheat to the railroad for shipment and paid the regular freight rate his wheat might lie there a month. If John Smith brought his wheat the next day and paid the "fast freight" rate, his wheat would be shipped immediately. My father often spoke of this as the "fast freight steal." 257

The same difficulties afflicted those who hauled their grain to Umatilla Landing for shipment downriver. What was needed and ardently sought after was a direct rail connection to the sea.

The needs of the Inland Empire farmers were met in the same way as were those of the miners of the 1860 s - by transportation entrepreneurs; although on a larger scale and at a slower pace. In January 1879, Dr. Baker sold six-sevenths of his stock in the Walla Walla and Columbia River Railroad to major stockholders of the Oregon Steam Navigation Company. Transportation magnate Henry Villard and other investors then purchased all of the holdings of the Oregon Steam Navigation Company and the remaining one-seventh stock in the Walla Walla and Columbia River Railroad later in 1879, retaining Dr. Baker as president. He and Dr. Baker "made excursions to Milton, Weston,

257 Willis, Early Recollections and Impressions of Umatilla County, 307. 
Dayton, and Waitsburg, which furnished conclusive proof of the extraordinary fertility and potentiality for development of that entire region." Villard wrote:

Owing to the great increase of the traffic down the Columbia during the preceding summer [1879] which far exceeded the capacity of the available river fleet, it was decided, instead of making additions to the fleet, to locate and construct without delay a line from Celilo to Wallula. 258

Construction on the segment from The Dalles to Wallula was begun on 13 February 1880 from both ends with a force of 2,000 men and 500 draft animals. Dr. Baker's line was relaid in standard gauge track. A fifteen mile branch line was also laid between Whitman Station and Weston, the first rail line in Umatilla County. On 1 July 1882 Villard reported to his stockholders the following:

There were completed the main line from The Dalles to Walla Walla (the narrow gauge to the latter point from Wallula had been changed to standard) 157 miles, and from The Dalles to the Cascades, 46 miles; the Baker City line from Umatilla to Pendleton, 44 miles. . .The last rail on the main line from Portland to Walla Walla was laid on October 3, 1882, three months ahead of the date promised. . .and the first through passenger train left Portland only on November 20, a historic date.

During 1883 another 56 miles was completed on the Baker City line and construction was begun on a new branch line from Walla

258 Henry Villard, The Early History of Transportation in Oregon,

(Eugene, OR: University of Oregon, 1944), 80-84; Baker, 12-13. 
Walla to Pendleton. The Baker City line over the Blue Mountains through Meacham connected with the Oregon Short Line, a subsidiary of the Union Pacific. This line, the first to reach Pendleton, on 11 September 1884, was variously referred to on maps and in the East Oregonian as the Baker City line, the Blue Mountain line, the Oregon Short line, the Huntington line, or the Union Pacific line. 259

The introduction of these lines had a tremendous impact on the economy of Umatilla County. By 1885, there were over 160,000 acres of wheat under cultivation, compared to 110,000 in Walla Walla County, 100,000 in Whitman County, and 80,000 in Columbia County. The agricultural growth over the preceding decade was tremendous:

\section{TABLE 5}

$\begin{array}{lrr} & \underline{1875} & \underline{1885} \\ \text { Acres in cultivation } & 14,745 & 234,878 \\ \text { Wheat exported, in \$ } & 137,575 & 1,401,420 \\ \text { Barley exported, in \$ } & 46,166 & 299,413 \\ \text { Wool exported, in \$ } & 322,366 & 1,638,656 \\ \text { Sheep, live } & 80,241 & 253,717\end{array}$

Forward-looking citizens anticipated even more growth in the immediate future. In April 1885 the first meeting of the County Board of Immigration was held to organize means to assist

259 Villard, 96-97; James B. Hedges, Henry Villard and the Railways of the Northwest, (New York: Russell \& Russell, 1930), 134. 
settlers. Ten thousand pamphlets extolling the many virtues of the county were ordered. The East Oregonian identified two obstacles to any further gratifying growth: the high tax rate (19 to 24 mills/dollar), and the high cost of transportation. 260

While the coming of the railroads to the Inland Empire was eagerly awaited, the program of government land grants to the railroads of alternating sections along the construction route received vigorous condemnation. Congress, in 1864, granted to the Northern Pacific all odd sections of land for forty miles on each side of the track in the Territories and for twenty miles in the states. By the time the Northern Pacific got around to filing its route for the railroad in the Columbia Basin with the Register of the General Land Office, much of the land had already been settled.261 This conflict is illustrated in the East Oregonian in 1885:

17 February - They [the United States Senate] are swift to curtail the privileges of the people; they will not even deign to consider the most infamous outrage upon the people ever hatched by traitorous tools of mammon with reference to the public land.

20 February - It is now apparent that a large slice of the most gigantic robbery of a free people by their agents and servants ever perpetrated in all the annals of civilized governments is about to pass into the absolute control and ownership of the Northern Pacific railroad

260 East Oregonian, 24 April, 25 May, 4 and 8 September 1885.

261 George W. Fuller, The Inland Empire of the Pacific Northwest, A History, (Spokane, WA: H. G. Linderman, 1928), 168-169. 
company. Yet though this company is a party to the robbery, and a partaker of the plunder, it is not really to be censured. It took no more than was given; and will hold, sell, and pocket the proceeds of, no more than is permitted by the infamous plunderers who are piling curses mountain high upon the country and calling them legislation. It is a mere matter of business with the company; nobody can blame it for making the best terms for itself it can. But for the National Congress, especially the Republican Senate, that devised and consummated the stupendous robbery, with utter disregard of all law and of their oaths, with open and unblushing depravity such as would have put to shame the Court of Charles I, with persistent cold-blooded disregard and despite of [sic] the plainest rights of the common people, with bribes in their open palms, lies upon their tongues, treason in their hearts-for them we say, let there by anathema, contempt, hatred, obloquy, ignominy, and undying detestation.

It is announced that the withdrawal of lands for the Cascade branch has taken place, and that such lands will be put upon the market at once and sold. These lands embrace over a million acres in Umatilla and Wasco counties. . .

The editor continued in this vein for several more paragraphs. On 3 March 1885 a large advertisement appeared in the East Oregonian stating in bold print, "Important to Settlers on Railroad Lands! And Others Who Desire to Purchase from the Company." Details followed with terms for the purchase of up to 320 acres per purchaser for $\$ 2.60$ to $\$ 6.00$ per acre, for cash or five to ten years credit terms, all land located west of range 31 east. 262

262 East Oregonian, 17 and 20 February, 3 March 1885. 
The obvious problem was that much of this land had already been settled under various homestead programs, some for as long as two decades. Now those settlers were required to purchase back their own land. It cannot be a coincidence that the East Oregonian began to carry more and more advertisements of Pendleton attorneys. The litigations continued almost to the end of the century.

In the meantime, the East Oregonian continued to publish frenzied attacks on the "Great Land Steal," intermixed with muted expressions of hope that more branch lines would be built. The 18 August 1885 paper published a letter from J. L. Killian urging the Northern Pacific to build a line up Vansycle Canyon to tap that rich wheatland: "Much of the opposition to their [Northern Pacific] land grant has died away." On 11 September 1885, the editor wrote: "The N. P. seems to be gaining in popularity; its low wheat rates East have made it many friends among the farmers and business men of Eastern Oregon." In the 20 October 1885 edition, the newspaper urged that a branch line be constructed up Vansycle Canyon: "What the farmers need-the great, urgent need above all others just now-is cheap transportation." Finally, the best illustration of mixed editorial emotions, the 17 November 1885 edition read:

The East Oregonian does not wish to "cinch" or hamper the railroads; but it believes in compelling them to give producers a chance. If either the railroads or the farmers must go to the wall, let it be the railroads. 
The editor could not decide whether to conciliate or vilify the Northern Pacific. In the end, economics conquered politics. ${ }^{263}$

Wheat farmers began to haul their sacks of grain by wagon to Wallula, the railhead for the Northern Pacific, from farther and farther away because of a ten cent per bushel price advantage. On 200 acres producing 30 bushels per acre, that would put $\$ 600$ more in the farmer's pocket than if he shipped via the Oregon Railway and Navigation Company to Portland and beyond.

Railroads also offered the farmer the flexibility to ship his harvest when and where prices were most advantageous. The East Oregonian quoted both Portland wheat prices in dollars and Liverpool prices in shillings and pence. 264

The line up Vansycle Canyon was finally built by George W. Hunt, well-known businessman and railroad entrepreneur. In 1889, the Oregon and Washington Territory Road, better known as the "Hunt System," ran from Hunt's Junction at Wallula to Fulton, Oregon, four miles north of Pendleton, a distance of thirty-four miles. In August, the line was completed to Pendleton. A branch extended from Stanton Junction east to Centerville (Athena), a distance of fourteen miles. Another line ran from Hunt's Junction northeast into the Palouse. The Hunt System was instrumental in bringing into production thousands of acres of Umatilla County. It

263 East Oregonian, 18 August, 11 September, 20 October, 17 November, 1885.

264 East Oregonian, 7 August 1885. 
and the other lines were also used to bring in wood for fences and construction on the newly settled farms. When Henry J. Taylor bought a quarter section of treeless wheatland eight miles northeast of Pendleton in September 1878, the trips to the Blue Mountains for wood and rails took two days. A few years later settlers could save many days arduous work thanks to the Hunt System. 265 (See Appendix D, Maps 4 and 5.)

When the Hunt road was approaching Pendleton, a few citizens who were unhappy with the exact location of the tracks coming into town, threatened to file an injunction. Hunt had the crew work throughout the last night, and: "People awoke this morning to find Hunt's railroad down Webb Street as far as the roller mills." When a branch line was extended from Pendleton to Pilot Rock in 1907, the rail system in Umatilla County was complete. 266

The need for the fencing of livestock became even more important with the presence of trains moving through farm lands. The East Oregonian frequently carried listings of horses and cattle killed by passing trains. The location of the tracks also caused farmers to petition for new roads to be opened and old roads to be vacated. In July 1891, for example, petitioners asked that a new county road be opened running generally next to the Pendleton-

265 Hedges, 156-157; Reminiscences, Henry J. Taylor, 160.

266 East Oregonian, 19 August 1889; Macnab, 69. 
to-Walla Walla line, and the old "Pendleton and Athena Reservation Road" be vacated. 267

The development of a railroad transportation system in the Columbia Basin meant prosperity for some communities and adversity for others. When the Oregon Railway and Navigation Company moved its division machine shops and ten-stall roundhouse from Wallula to Umatilla, and the Northern Pacific moved its facilities from Wallula to Pasco, Wallula's population was cut in half. Umatilla enjoyed a revival from the loss of the county seat to Pendleton, while Wallula reverted to a more lonely existence. Walla Walla found itself on a branch line since the Northern Pacific did not build through there, as Dr. Baker had hoped. Pendleton, on the other hand, had always been in the shadow of Walla Walla. Now, at the end of the century, it found itself in the fortunate position of being located along a transcontinental line and at the junction of a line to Wallula and another to Walla Walla. As Meinig wrote: "The railroad was the most decisive arbiter of these competitions and at times could affect the prospects of a town even well after it had been granted its coveted facilities." 268

A complete history of the establishment of railroads in the Inland Empire is beyond the scope of this thesis. Clearly the effect of the development of the rail system was revolutionary.

267 Commissioners' Journal H, 765-766, 9 July 1891.

268 Meinig, 324-327, 348-349. 
After all the railroad building, competition, failing, and merging had played out, a fast, efficient and competitive system for passenger and freight existed by the end of the nineteenth century. In addition to breaking the downriver transportation monopoly, railroad companies also offered express services to compete with the ubiquitous Wells, Fargo and Company.

In 1890 Umatilla County produced around 5 million bushels of wheat, one-third of the entire state production. By 1897 , Umatilla County produced over $44 \%$ of the total state wheat harvest. This increase was due to settlement of lands opened up by the introduction of rail transportation. This impact of a new system of transportation was felt not only in the shipment of agricultural products, but also in fast and safe passenger service. Mrs. A. J. Black remembered her arrival in Umatilla County: "We came by railroad, on one of the old emigrant trains and it took us eight days to come from Illinois to Umatilla." Through the efforts of Henry Villard and the Northern Pacific, immigrants could purchase railway tickets at substantial discounts to come to the Inland Empire. Many did come, shipping their household goods in freight cars. Villard also had agents throughout Europe promoting emigration to the Northwest. They could step off the train in Walla Walla or Pendleton, walk in to the land agent's office, and within a few weeks begin to farm. The East Oregonian carried 
numerous advertisements of the land agents doing business in the county. 269

By 1893 the system of shipping agricultural products out of Umatilla County was well-developed. Wheat warehouses and loading platforms operated along all the rail lines. From Pendleton toward Umatilla, these facilities were located at Barnhart, Yoakum, Nolin, and Echo. From Pendleton toward Walla Walla, they were at Saxe, Adams, Athena, Weston, Blue Mountain Station, Milton, and Spofford. On the Hunt System lines, facilities were at Fulton, Warren, Helix, Stanton, Vansycle, Cañon, Hilsdale, and Waterman. 270

Wheat was not shipped or stored in bulk; sacks were filled by the combines and sewn shut in the field. Old photographs show neat stacks of thousands of sacks of grain on platforms or in overflowing warehouses awaiting shipment. Even with the railroad lines fully integrated into the transportation system, farmers still used horses and mules to haul the sacks to the rail loading facilities. The need for good roads to connect with these locations kept' the county court busy granting petitions for new or altered road sections as more and more land was cultivated.

269 Parsons, 160-162; Hedges, Chap. 6, for details of Villard's extensive efforts to colonize the Columbia Basin.

270 Arnold's Map, 1893, indicates by a pennant with a "W" each wheat loading facility, demonstrating the importance of transportation to the wheat culture and the economy of Umatilla County. 
Residents of Umatilla County could look forward to the new century with every expectation of growth and prosperity.

According to County Surveyor John C. Arnold, Umatilla County had 211 miles of railroads in 1893. Most of these railroads followed ancient Indian trails, as did the major wagon roads. The Baker City Line from Umatilla, through Pendleton, and across the Blue Mountains followed Indian trails for virtually its entire length. The Oregon Railway and Navigation road to Wallula was laid down on top of the Columbia Trail of Indian antiquity. Long portions of the railroad from Pendleton to Walla Walla followed wagon roads which were based on Indian trails. Only the Hunt System line was, for much of its length, laid on new ground, and even then, the segment up Vansycle Canyon followed an Indian trail. Taken with the many wagon roads based on Indian trails, the overall pattern of movement within the transportation system of Umatilla County was remarkable for its invariability over time. 
CHAPTER 10

\section{CONCLUSION}

Three revolutionary changes in transportation in the Umatilla Country occurred during the nineteenth century. The first was the introduction of horses, which was the most revolutionary of the three. This fundamental change not only altered the land-use pattern of the human geography, it also changed the whole social and cultural system of the Indians who had operated within a very stable hunter-gatherer lifeway. The vast grasslands became important as the means to sustain horse herds that were at once a provider of transportation, a measure of warfare, wealth and stature, and a living currency in the active trading culture of Northwest Indians. The introduction of horses established grazing as the dominant land-use pattern until the decade of the $1880 \mathrm{~s}$.

The second fundamental change was the introduction of wheeled vehicles to the region. Wagons were crucial to the settlement of the isolated Inland Empire. The movement of the fur trappers and traders by horseback and canoe was superimposed onto the patterns long established by the Indians. For the permanent colonization and establishment of an agriculture-based economy in the Umatilla Country, wagons were indispensable. When whole families began to arrive with wagons 
containing the few household items to start a pioneer farm, they also brought the vehicle that would be used to transport the farm products in excess of their needs and available for barter or sale. A few mountain men could subsist with a horse and pack mule, but a farmer could not exist without a wagon. The introduction of the wheeled vehicle caused horse trails to be transformed into wagon roads. Road conditions directly affected if, when, and where immigrants went in the Umatilla Country. The successful development of an agriculture-based market economy was due to the operation of wheeled vehicles moved by animal traction along a road system designed and maintained for wagon use.

The third fundamental change to transportation in the Umatilla County was the introduction of steam power. Prior to the introduction of steam navigation on the Columbia River, movement by canoe or flatboat was accomplished with relative ease downriver and with extreme difficulty upriver. The strong current limited the ability of cargoes to be carried upriver, even with the aid of sails. Steamboats made the Columbia River a twoway highway of the Northwest. The shallow draft and large capacities provided efficient, if expensive, trade and communications with the interior. The coming of the railroads made the final link between Umatilla County and the rest of the region, nation, and globe. The efficiency, speed, and safety of the railroads assured the settlement and prosperity of Umatilla County. Steam power allowed the region to transform the 
dominant land-use form from one of livestock grazing to one of agricultural export. Even with the success of dryland farming and sheep ranching, the development of the economy would have been stunted without this revolutionary form of transportation.

The history of transportation in Umatilla County has witnessed many surges in the pattern of movement. The introduction of horses early in the eighteenth century led to an explosion of movement within and beyond the traditional range of the Indians of the Umatilla Country. As this new means of transportation became incorporated into the culture and society of the tribes, annual cycles of movement developed. When the fur companies began operating in the Old Oregon Country, their movements were also based on annual cycles.

The next surge was the westbound immigration of pioneers who began in the 1840 s to pass over the Oregon Trail and through the Umatilla Country. While this migration continued, another surge ran in the opposite direction in the gold rushes of the late 1850 s and 1860s. This movement of both people and livestock led directly to the permanent settlement of Umatilla County. Since many of the major routes to the gold mining regions crossed Umatilla County, the early economy was based on transportation and supply of the miners. When the potential of dryland wheat farming became known, another surge of movement led to the settlement of the rich grasslands of the Walla Walla and Palouse regions, and finally Umatilla County. These patterns of movement 
developed from the simple to the complex, from the westward movement of wagon trains along the great immigrant highway to the complex movement of miners, farmers, livestock ranchers, and those who supported them throughout the county and region. Immigrants in the 1890 s came from all directions. The busy routes of river, road, and rail served to fully integrate Umatilla County into the state and nation by the end of the nineteenth century.

The history of transportation in Umatilla County has provided opportunities for countless entrepreneurs, beginning with Dr. Marcus Whitman. Although he would be mortified to be considered a tradesman, the passing immigrants provided him a means to sustain the mission at Waiilatpu. The Indians may not have learned much of Christianity from his example, but many learned to trade profitably with the westering pioneers.

If the mining boom caused the most vigorous surge of movement, it also caused a burst of entrepreneurial activity to "mine the miners." Those involved in the packing, freighting, express, and stage business became some of the first residents of Umatilla County. Every need was eagerly met, at a price. When people went to even the most remote areas in search of gold, someone of energy came to provide whatever aspect of transportation deemed necessary. And the boom was not limited to those directly involved in conveying people and goods; many more were employed in ancillary activities. They worked as 
blacksmiths, horse tenders, cooks, innkeepers, express agents, and clerks. They raised sheep and cattle to trail to the mines, and they grew grains and vegetables to sell to everyone else. So many of the early settlers of Umatilla County had worked in some aspect of transportation that they came naturally to give their support to efforts to maintain and improve the transportation system. Often these early activities in transportation led to more settled lives as the county itself became more settled. Many prosperous farmers and merchants got their start working in transportation. By the 1890s, manufactured goods could be imported and agricultural products could be exported with relative ease.

In conclusion, the patterns of transportation in Umatilla County have been remarkably long-lasting. Certainly not all, but most of the major pathways of travel of the Indians became the basis for road and rail routes of the system of transportation existing at the end of the nineteenth, if not the twentieth century. That proved to be extremely fortuitous for the white settlers of Umatilla County, and disastrous for the Indians. Their ancestral lands and their diminished reservation were dissected by routes of travel too long established to change. The same long-lasting nature of the patterns of transportation, so costly to the Indians, provided the means of sustained agricultural and economic development in Umatilla County. From the days of long journeys to hunt buffalo or trap beaver to the expeditious shipment of flour 
to Liverpool, transportation was the crucial ingredient to economic success. 


\section{APPENDIX A \\ COUNTY COURT OF UMATILLA COUNTY \\ PREAMBLE AND RESOLUTION \\ IN THE MATTER OF ROADS \\ SEPTEMBER TERM 1865}

In the matter of Roads

At the Regular term of the County Court of Umatilla County, for Sept A.D. 1865

Present the Hon. R. B. Moorford, Wm Mitchell Commissioner, the following preamble and Resolution were adopted.

Whereas We are satisfied that a Road leading from Umatilla City, Via, McKay Creek and connecting with the old Emigrant Road at or near the summit of the Blue Mountains would be conducive to the Best Interests of Eastern Oregon, and of the Mining Settlements in the Territories, dependent upon the Columbia River for Supplies,

And, Whereas Said Road would necessarily pass through a portion of Umatilla Indian Reservation

And, Whereas We have been informed that the Hon James W. Nesmith, U. S. Senator from Oregon, \& Special Agent, appointed for the purpose of Examining Indian Agencies \& has expressed a Willingness to Assist in Establishing said Road, Therefore

Resolved, that, we hereby request Senator Nesmith to use his influence with the President to have a Road established through said Reservation, on the Route above indicated - Said Road to be hereafter more particularly located \& Surveyed in conformity with the laws of Oregon, by Viewers and a Surveyor appointed by the County Court of Umatilla County. 
Resolved, That in making this Request we believe that we are acting in Conformity with the Views and wishes of the people generally in this portion of the County

Resolved, That we are informed and believe that the proposed Road would be about eight miles shorter and would pass over a better grade than the Road now Generally travelled from Umatilla City across the Blue Mountains.

[Transcribed with original punctuation from Umatilla County Commissioners' Journal A, pages 148-149.] 


\section{APPENDIX B}

\section{UMATILLA COUNTY SPECIAL TERM APRIL 1866 \\ IN THE MATTER OF ESTABLISHING A COUNTY ROAD}

A petition having been filed on this 16 th day of April 1866 to establish a County Road commencing at Umatilla City and running by way of the 12 Mile House thence by the best and most practable [sic] rout to Birch Creek thence crossing over to the Umatilla Indian Reservation thence passing through said Reservation Via McKay Creek and connecting with the Old Emigrant Road at or near the Summit of the Blue Mountains; and it appearing that said Petition is numerously signed by Citizens of Umatilla County, including not less than twelve householders residing in the vicinity where said road is to be laid out, and that said Road would be of great public convenience and it further appearing that permission has been granted by Hon D. N. Cooley, Commissioner of Indian Affairs, to Survey said road through the Indian Reservation; and satisfactory evidence having been produced that notices of said petition have been posted for more than 30 days at the County Seat and also in three Several places along the proposed line of said road; It is therefore ordered that said petition be granted, and that the Survey commence at some convenient point on the present County road near the 4 Mile House and run thence to the points designated in the petition and it is also ordered that Lucian Everts, Henry Bowman and M. B. Burk be appointed Viewers and that they, in connection with the County Surveyor, proceed to View and Survey the said road on the 21 st of May 1866 and that upon reaching the Reservation that said Viewers shall give $\mathrm{Wm} \mathrm{H}$. Barnhardt Esqr notice that they are 
about to proceed through the Reservation in order that he may explain the nature of their proceedings to the Indians And it is further ordered that in case of the absence or inability of the County Surveyor to act at the time appointed for the commencement of said Survey the viewers may then proceed to employ any other competent Surveyor to make said Survey at rates not exceeding those allowed by law to the County Surveyor.

[Transcribed with original punctuation from Umatilla County Commissioners' Journal A, pages 241-242.] 


\title{
APPENDIX C
}

\author{
REPORT, SURVEY \& PLAT OF CO. ROAD \\ FROM UMATILLA CITY VIA MCKAY CR. TO \\ BLUE MTS. ON MEACHAM ROAD
}

To the Hon. County Court of Umatilla County, Oregon:

We the undersigned viewers appointed at the April term of this Court for the year 1866 to survey and locate a County Road leading from Umatilla City to a point at or near the summit of the Blue Mountains, by the way of the 12 Mile house, Birch creek and McKay creek, beg leave to submit the following final report:

1 st That we recommend that the route set forth in the report and map of Mr. J. H. Sharon, surveyor, herewith filed, and leading from Umatilla City, by way of the 12 Mile House and crossing the Umatilla River at the ranch of Mr. James R. Means and proceeding from thence by way of the Jones Canyon Birch creek and McKay creek, and proceeding from thence to the Meacham road by what is known as the Hull trail be established and declared a County road.

2nd That the route viewed by us, and set forth on the map of Mr. Sharon, commencing at the 12 Mile House, and crossing the Umatilla river at the ranch of Mr. L. Everts where it again connects with the main route above recommended by also declared a County road.

3 rd That the road supervisors of this County be authorized in performing labor on public highways passing through unimproved lands, to vary from the surveyed routes; where in their opinion the best interests of the public demand it.

4th That the County be laid off into suitable road districts and road supervisors be appointed therefor, as soon as the law 
will permit. We recommend the establishing of the main route above indicated as a County road, for the reason that we believe that it would be a convenience to the traveling public generally, as a public thoroughfare leading from the Columbia river to the mining and farming country in the eastern portion of this State and Idaho Territory: and that it would be a great benefit to the settlers living in the vicinity of the proposed road furnishing them, as it would with a home market for their produce and means for transporting it elsewhere. It would also materially lessen the distance which emigrants and others are compelled to travel in going overland from places east of the Blue Mountains to Western Oregon.

The route recommended which crosses the Umatilla river at Mr. Evert's ranch is merely a subdivision of the main route, and nearly one mile shorter in distance. Owing to the great length of the route the health of one the viewers and the pressing business engagements of the others we have not been able to make as thorough an examination of it as we had hoped and deemed desirable. We are convinced that in several places the distance could be lessened and the route improved by a resurvey. Still by allowing road supervisors to change the route through unimproved lands where they may deem it advisable, this evil can be remedied to a considerable extent. It is obvious that but little if any improvement will be made on the road until it is laid off into districts and supervisors appointed. Our recommendation in regard to that matter, therefore, needs no further argument.

All of which is respectfully submitted.

[signed] Lucian Everts

M. B. Burk

Henry Bowman, viewers 
We would further state that: In pursuance of the order adopted by the County Court at its last July term, we have spent some time in examining the route originally viewed and surveyed by us during the month of June last a map of which is now on file in this Court, but that we have finally concluded to adopt that portion of the original survey hereinafter specified, \& recommend its adoption by the Court, as a County road. There are some portions of the route originally surveyed by us which might perhaps be improved by a re-survey but the great expense attending such a proceeding would probably overbalance any benefit which would be derived from it; besides our business engagements are of such a nature that we do not feel justified in devoting further time to the business of viewing the road for the compensation allowed by law. The route recommended by us for adoption as a County road is the one set forth in the surveyor's map herewith filed, which follows the main course of the Umatilla river and crosses it near the 21 st mile post; thence following along the southern side of the river as far as the mouth of the Jones Canyon; thence via Jones Canyon to Birch creek, thence to the Forks McKay creek, thence to what is known as the Meacham road by way of the southerly route, set forth on the map, which ascends the Blue Mountains at the Forks of McKay creek and forms a junction with the Meacham road about $21 / 3$ miles beyond Meacham's station, and near the 64 mile post.

[signed]Lucian Everts

Henry Bowman

viewing

\section{Field Notes}

[There follows the technical field notes as certified by J. H. Sharon, surveyor, including courses, distances, and remarks. Transcribed with original spelling and punctuation from County Roads and Field Notes, Volume A, pages 2-4.] 


\section{APPENDIX D \\ MAP 1 \\ Umatilla County}

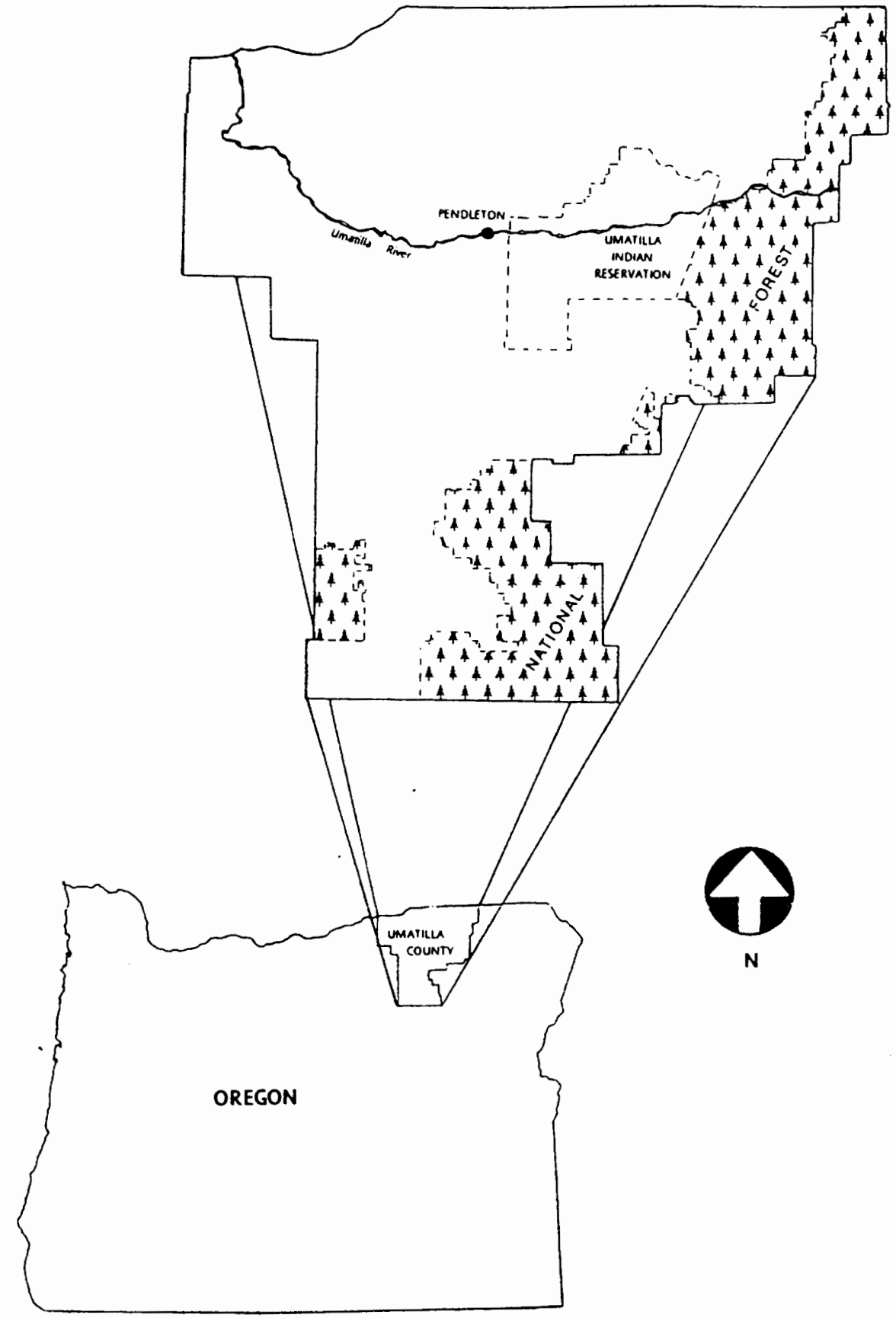




\author{
APPENDIX D \\ MAP 2 \\ Roads over the Blue Mountains
}

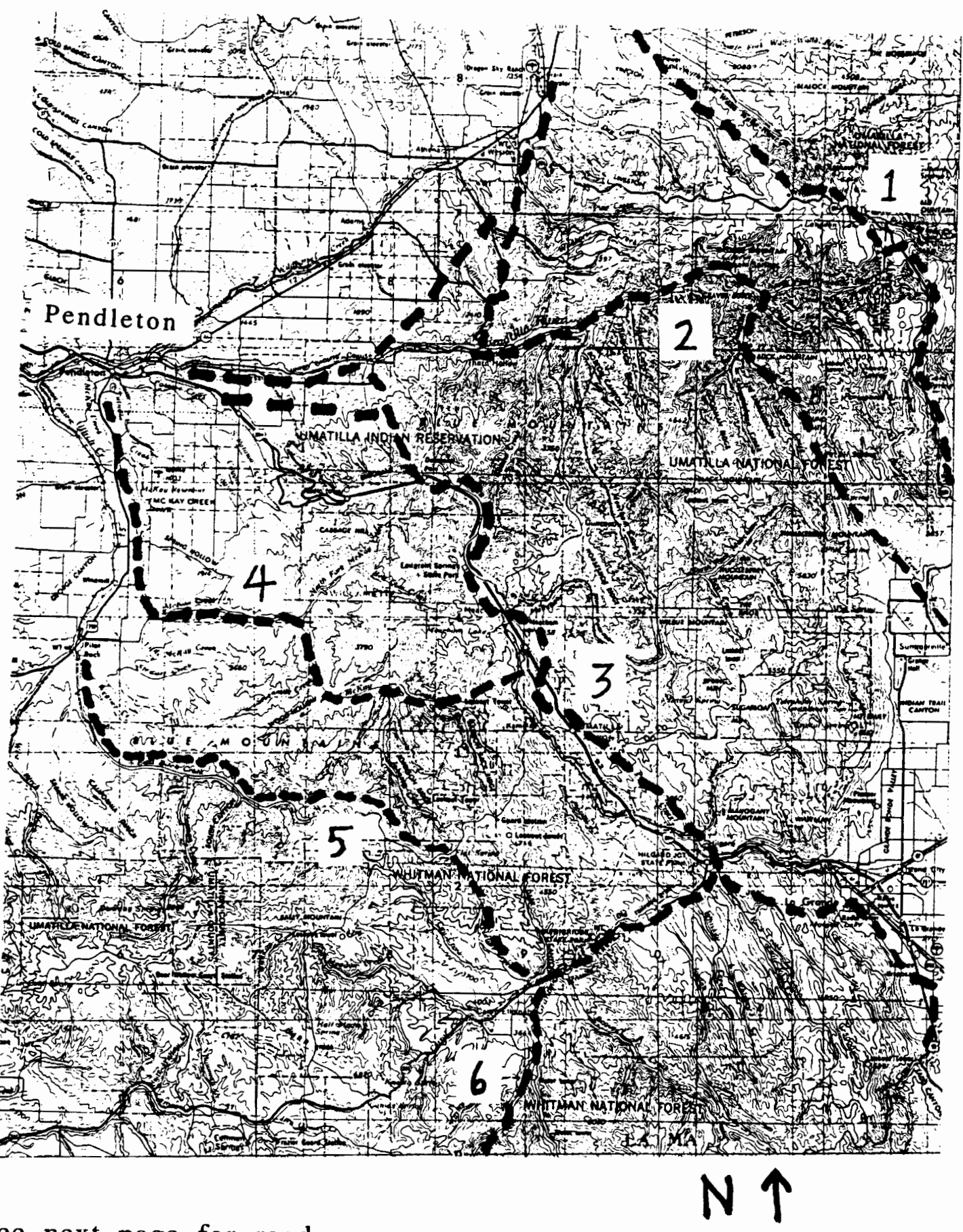

See next page for road names. 
Maps 2, 3, and 4 are taken from the uncopyrighted U. S. Geological Survey Map, 1:250,000 scale, titled "Pendleton."

Pioneer roads across the Blue Mountains in Map 2 are:

1 - Lincton-Woodward Road

2 - Thomas-Ruckel Road

3 - Oregon Trail

4 - Hall Trail Branch of Oregon Trail

5 - Indian Service Road

6 - Daley Toll Road 


\section{APPENDIX D \\ MAP 3}

Pioneer Wagon Roads in Western Umatilla County

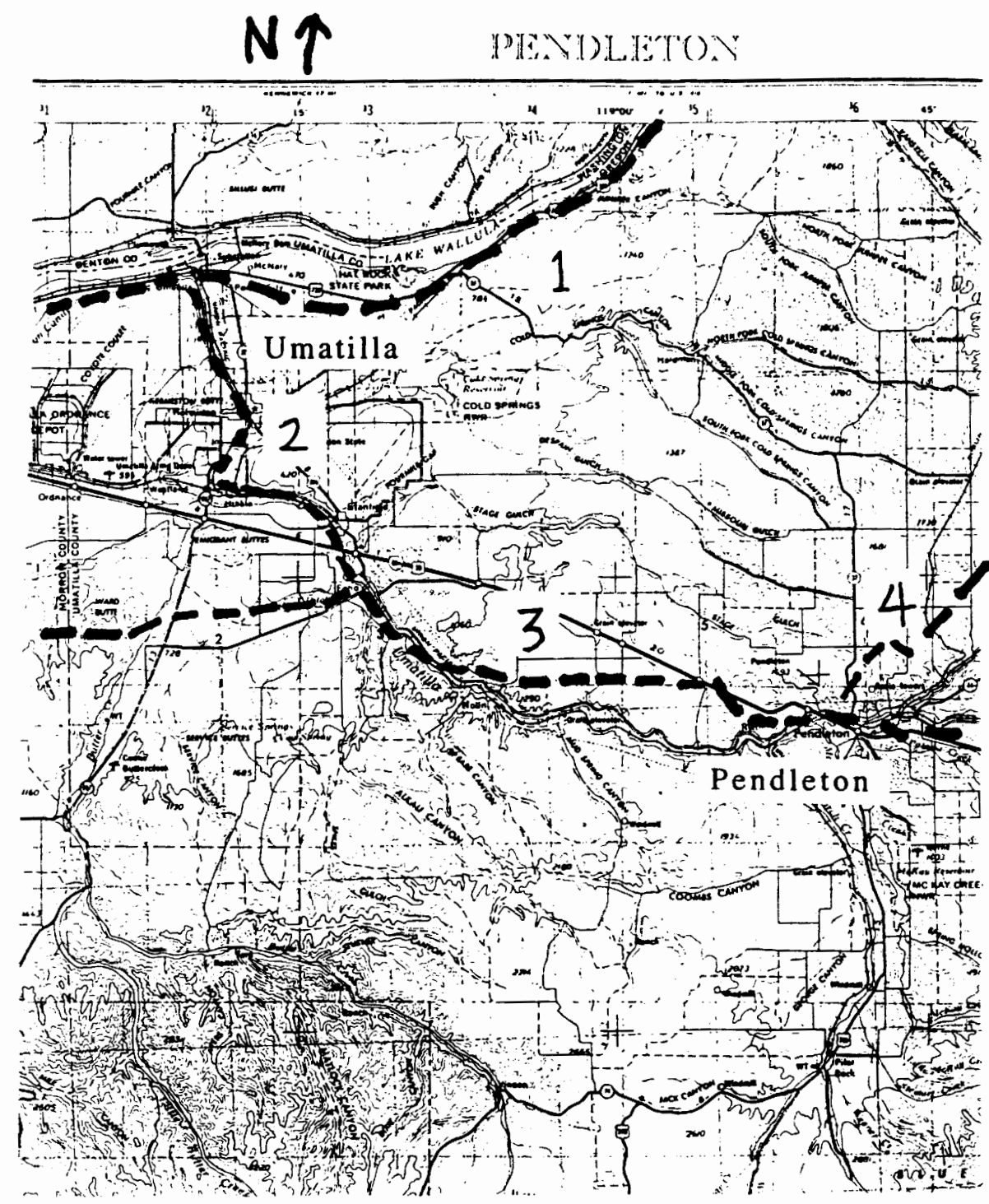

See next page for road names. 
Pioneer roads in western Umatilla County indicated in Map 3 are:

1 - The Dalles-Walla Walla Road

2 - Umatilla-Pendleton Road

3 - Oregon Trail

4 - Walla Walla Cutoff 


\section{APPENDIX D \\ MAP 4 \\ Railroads in Umatilla County}

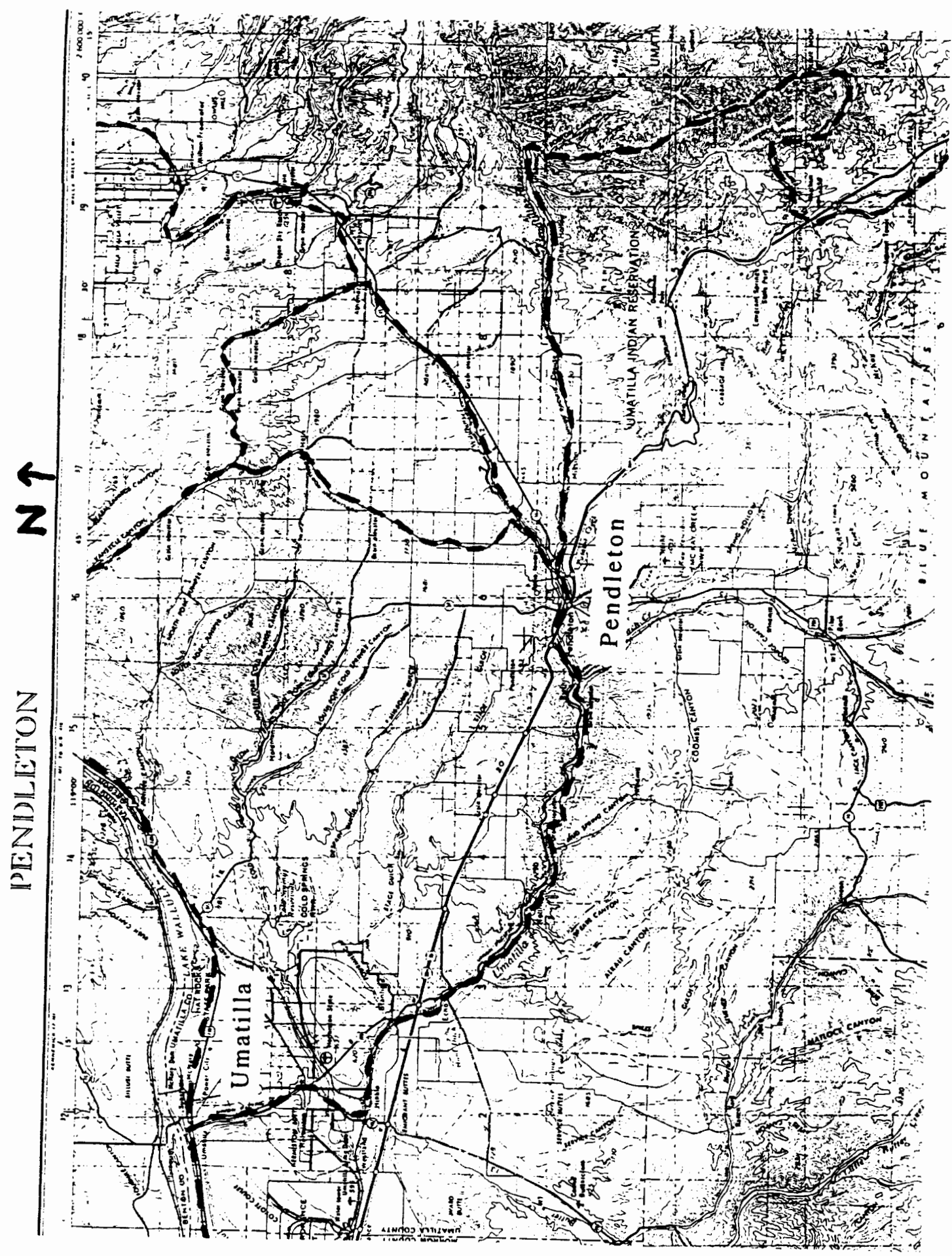




\section{APPENDIX D MAP 5}

Walla Walla-Wallula Railroads

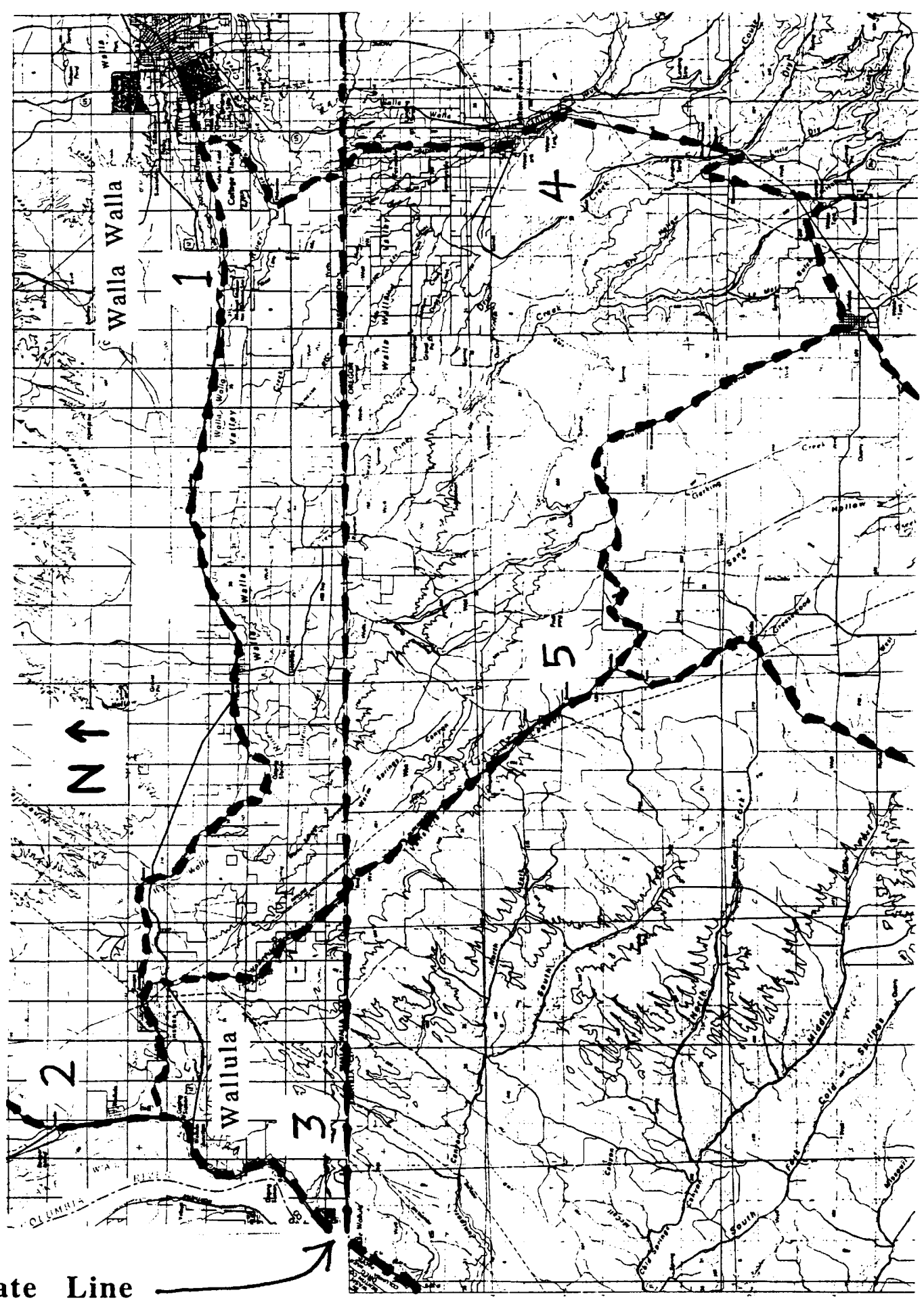


Walla Walla-Wallula Railroads indicated in Map 5 are:

1 Walla Walla and Columbia River Railroad (Dr. Baker's railroad.

2 Northern Pacific Railroad.

3 Oregon Railway and Navigation Line.

4 Pendleton-Walla Walla Branch Line.

5 Oregon and Washington Territory Road (Hunt's System Railroad). 


\section{BIBLIOGRAPHY}

\section{Books}

Bancroft, Hubert Howe. Bancroft's Works, Volume 30, History of Oregon, Vol. II (1848-1888). San Francisco: The History Company, 1888.

Barker, Burt B., ed. Letters of Dr. John McLoughlin Written at Fort Vancouver, 1829-1832. Binfords \& Mort for the Oregon Historical Society, 1948.

Bland, Thomas A. Life of Alfred B. Meacham. Washington, D. C.: T. A. and M. C. Bland, 1883.

Borth, Christy. Mankind on the Move, The Story of Highways. Washington, D. C.: Automotive Safety Foundation, 1969.

Deady, Matthew P., comp. and annotated. The Organic and Other General Laws of Oregon together with the National Constitution and Other Public Acts and Statutes of the United States, 1845-1864. Portland: Henry L. Pittock, State Printer, 1866.

Drury, Clifford M. Marcus and Narcissa Whitman and the Opening of Old Oregon. 2 Volumes. Glendale, CA: The Arthur H. Clark Co., 1973.

Evans, John W. Powerful Rockey: The Blue Mountains and the Oregon Trail, 1811-1883. La Grande, OR: Eastern Oregon State College, 1990.

Farnham, Thomas J. Travels in the Great Western Prairies. Cleveland, 1906, reprint, Monroe, OR: Rodney R. McCallum, 1977.

Forster, Dale E. Oregon Express Companies. Lake Oswego, OR: Raven Press, 1985. 
Franchère, Hoyt C., ed. and trans. The Overland Diary of Wilson Price Hunt. Ashland, OR: The Oregon Book Society, 1973.

Frederick, J. V. Ben Holladay: The Stagecoach King; A Chapter in the Development of Transcontinental Transportation. Glendale, CA: The Arthur Clark Co., 1940.

Franzwa, Gregory M. The Oregon Trail Revisited. Fourth edition. Tuscon, AZ: The Patrice Press, 1988.

Fuller, George W. The Inland Empire of the Pacific Northwest, A History. Spokane, WA: H. G. Linderman, 1928.

Gilbert, Frank T. Historic Sketches of Walla Walla, Whitman, Columbia and Garfield Counties, Washington Territory. Portland: A. G. Walling, 1882.

Hailey, John. The History of Idaho. Boise, ID: Syms-York Co., 1910.

Haines, Francis D. Jr., ed. The Snake Country Expedition of 1830-1831, john Work's Field Journal. Norman, OK: University of Oklahoma Press, 1971.

Hedges, James B. Henry Villard and the Railways of the Northwest. New York: Russell \& Russell, 1930.

Hooker, William F. The Prairie Schooner. Chicago: Saul Brothers, 1918.

Hulbert, Archer B. The Paths of Inland Commerce, A Chronicle of Trail, Road, and Waterway. New Haven: Yale University Press, 1920.

Indian Thoroughfares. Vol. 2 "Historic Highways of America. New York: AMS Press, 1971.

Hulbert, Archer B. and Dorothy P. Hulbert, eds. Overland to the Pacific. 8 Volumes. Denver: The Stewart Commission of Colorado College and the Denver Public Library, 1938. 
Hunn, Eugene S. with James Selam and family. Nch'i-Wána, "The Big River": Mid-Columbia Indians and Their Land. Seattle: University of Washington Press, 1990.

Irving, Washington. Astoria. Portland: Binfords \& Mort, undated "Clatsop Edition."

The Adventures of Captain Bonneville. Norman, OK: University of Oklahoma Press, 1961.

Kappler, Charles J., comp. and ed. Indian Treaties 1778-1883. Mattituck, NY: Amereon House, 1972.

Lockley, Fred. Conversations with Bullwhackers \& Muleskinners. Compiled and edited by Mike Helm. Eugene, OR: Rainy Day Press, 1981.

Lomax, Alfred L. Later Woolen Mills In Oregon, A History of the Woolen Mills Which Followed the Pioneer Mills. Portland: Binfords \& Mort, 1974.

Macnab, Gordon. A Century of News and People in the East Oregonian, 1875-1975. Pendleton: East Oregonian Publishing Co., 1975.

McArthur, Lewis A. Oregon Geographic Names. Fourth edition. Portland: Oregon Historical Society, 1974

Meinig, D. W. The Great Columbia Plain, A Historical Geography, 1805-1910. Seattle: University of Washington Press, 1968.

Merk, Frederick, ed. Fur Trade and Empire: George Simpson's Journal. Cambridge: Harvard University Press, 1931.

Mossman, Isaac V. A Pony Expressman's Recollections. Portland: The Champoeg Press, 1955.

Moulton, Gary E., ed. The Journals of the Lewis \& Clark Expedition. 8 Vols. Lincoln: University of Nebraska Press, 1983.

Nielsen, Lawrence E. In the Ruts of the Wagon Wheels, Pioneer Roads in Eastern Oregon. Bend, OR: Maverick Publications, 1987. 
Roads of Yesterday in Northeast Oregon. Bend, OR: Maverick Publications, Inc., 1990.

Oliphant, J. Orin. On the Cattle Ranges of the Oregon Country. Seattle: University of Washington Press, 1968.

Oliver, Herman. Gold and Cattle Country. Edited by E. R. Jackman. Portland: Binfords \& Mort Publishers, 1961.

Olson, Conrad P., comp. and annotated. Oregon Laws Showing All the Laws of a General Nature in Force in the State of Oregon including the Special Session of 1920. San Francisco: The Bancroft Whitney Co., 1920.

Parsons, William and W. S. Shiach. An Illustrated History of Umatilla County and of Morrow County. W. H. Lever, 1902.

Pioneer Ladies' Club, comp. Reminiscences of Oregon Pioneers. Pendleton, OR: East Oregonian Publishing Co., 1937.

Rollins, Philip A., ed. The Discovery of the Oregon Trail, Robert Stuart's Narratives. New York: Charles Scribner's Sons, 1935.

Ross, Alexander. The Fur Hunters of the Far West. Edited by Milo M. Quaife. Chicago: R. R. Donnelley \& Sons Company, 1924). Adventures of the First Settlers on the Columbia River. Ann Arbor: University Microfilms, Inc., 1966.

Adventures of the First Settlers on the Oregon or Columbia River. Edited by Milo M. Quaife. New York: The Citadel Press, 1969.

Ruby, Robert H. and John A. Brown. Ferryboats on the Columbia, including Bridges and Dams. Seattle: Superior Publishing Co., 1974.

Searcey, Mildred. Way Back When. Pendleton, OR: East Oregonian Publishing Company, 1972. 
We Remember. Pendleton, OR: East Oregonian Publishing Company, 1973.

Strahorn, Carrie Adell. Fifteen Thousand Miles by Stage, Volume 1: 1877-1880. Lincoln: University of Nebraska Press, 1988.

Suphan, Robert J. with D. A. Horr, ed. Oregon Indians II, Ethnological Report on the Umatilla, Walla Walla, and Cayuse Indians Relative to Socio-Political Organization and Land Use. New York: Garland Publishing Inc., 1974.

Taylor, George R. The Transportation Revolution, 1815-1860. New York: Rinehart, 1951.

Trimble, W. J. Mining Advance into the Inland Empire. University of Wisconsin Studies, History Series, Vol. III, No. 2. Madison, 1914.

Tucker, Gerald J. Pioneer Roads of The Blue Mountains. Unpublished manuscript, 1962. Penrose Library, Whitman College, Walla Walla, Washington.

Umatilla County Historical Society. A Backward Glance. Pendleton, OR: E. O. Master Printers, 1981.

Unruh, John D., Jr. The Overland Emigrants and the TransMississippi West, 1840-1860. Chicago: University of Illinois Press, 1979.

Victor, Francis F. The Early Indian Wars of Oregon. Salem, OR: Frank C. Baker, State Printer, 1894.

Villard, Henry. The Early History of Transportation in Oregon. Eugene: University of Oregon, 1944.

Wentworth, Edward N. America's Sheep Trails. Ames, Iowa: The Iowa State College Press, 1948.

Wilkes, Charles. Narrative of the U. S. Exploring Expedition.

2 Volumes. Philadelphia: Lea \& Blanchard, 1845. 
Winther, Oscar O. The Old Oregon Country, A History of Trade, Transportation, and Travel. Lincoln: University of Nebraska Press, 1950.

. The Transportation Frontier, Trans-Mississippi West, 1865-1890. New York: Holt, Rinehart and Winston, 1964.

Young, F. G., ed. Sources of the History of Oregon. Eugene, OR: University Press, 1899.

\section{$\underline{\text { Journal Articles }}$}

Atkin, W. T. Snake River Fur Trade, 1816-1824. Oregon Historical Quarterly Vol. 35 (December 1934): 295-312.

Baker, W. W. The Building of the Walla Walla and Columbia River Railroad. The Washington Historical Quarterly Vol. 14 (January 1923): 3-13.

Barrett, C. A. Early Farming in Umatilla County. Oregon Historical Quarterly Vol. 16 (1915): 343-349.

Elliot, T. C., ed. Journal of the Alexander Ross Snake River Expedition. Oregon Historical Quarterly Vol. 14 (December 1913): $366-388$.

. Journal of David Thompson. Oregon Historical Quarterly Vol. 15 (March 1914): 39-63.

- The Dalles-Celilo Portage: Its History and Influence. Oregon Historical Quarterly Vol. 16 (June 1915): 133-174.

. The Mullan Road: Its Local History and Significance. The Washington Historical Quarterly Vol. 14 No. 3 (July 1923): 206-209.

- The Coming of the White Women, 1836. Oregon Historical Quarterly Vol. 37 (June 1936): 87-101.

Evans, Hartman K. with Robert H. Burns, ed. Sheep Trailing from Oregon to Wyoming. Mississippi Valley Historical Review Vol. 28 No. 4 (March 1942): 581-592. 
Haines, Francis. The Northwest Spread of Horses Among the Plains Indians. American Anthropologist Vol. 40 (1938): 429-437.

Gamboa, Erasmo. Mexican Mule Packers and Oregon's Second Regiment mounted Volunteers, 1855-1856. Oregon Historical Quarterly Vol. 92 (Spring 1991): 41-59.

Garth, Thomas R., Jr. Waiilatpu after the Massacre. The Pacific Northwest Quarterly Vol. 38 (October 1947): 315-318.

Gillette, P. W. A Brief History of the Oregon Steam Navigation Company. Oregon Historical Quarterly Vol. 5 (June 1904): 120-132.

Holman, Frederick V. History of the Counties of Oregon. Oregon Historical Quarterly Vol. 11 No. 1 (1910): 1-81.

Johnson, Overton and William H. Winter. Route Across the Rocky Mountains, with a Description of Oregon and California. Oregon Historical Quarterly Vol. 7 (March 1906) 62-104; (June 1906) 163-210; (September 1906) 291-327.

Lee, Jason. Diary of Jason Lee. Oregon Historical Quarterly Vol. 17 (September 1916): 240-266.

Minto, John. Sheep Husbandry in Oregon; the Pioneer Era of Domestic Sheep Husbandry. Oregon Historical Quarterly Vol. 3 (September 1902): 219-247.

Nesmith, James W. Diary of the Emigration of 1843. Oregon Historical Quarterly Vol. 7 (December 1906): 329-359.

Poppleton, Irene L. Oregon's First Monopoly. Oregon Historical Quarterly Vol. 9 (September 1908): 274-304.

Prosch, Thomas W. Notes From a Government Document on Oregon in the Fifties. Oregon Historical Quarterly Vol. 8 No. 2 (1907): 191-200. 
Ray, Verne F. Native Villages and Groupings of the Columbia Basin. Pacific Northwest Quarterly Vol. 27 ( April1936): 99-152.

et al. Tribal Distribution in Eastern Oregon and Adjacent Regions. American Anthropologist n.s. Vol. 40 (July-September 1938): 384-415.

Scott, Leslie M. The Pioneer Stimulus of Gold. Oregon Historical Quarterly Vol. 18 ( September 1917): 147-166.

Stewart, Earl K. Transporting Livestock by Boat Up the Columbia, 1861-1868. Oregon Historical Quarterly Vol. 50 (December 1949): 251-259.

Strong, Dexter K. Beef Cattle Industry in Oregon. Oregon Historical Quarterly Vol. 41 No. 3 (September 1940): 251-287.

Talkington, Henry L. Story of the River-Its Place in Northwest History. Oregon Historical Quarterly Vol. 16 (June 1915): $181-195$.

Watt, James W. Experiences of a Packer in Washington Territory Mining Camps during the Sixties. Washington Historical Quarterly Vol. 19 (July 1928): 206-213.

Willis, Park W. Early Recollections and Impressions of Umatilla County, Oregon. The Pacific Northwest Quarterly Vol. 28 (July 1937): 301-311.

$\underline{\text { Maps }}$

Arnold's Official Map of Umatilla County, County Courthouse, Pendleton, Oregon.

General Land Office Platbook for Umatilla County, May 1885, County Courthouse, Pendleton, Oregon.

General Land Office Survey Maps, Bureau of Land Management, Portland, Oregon.

U. S. Geological Survey Map.

Newspapers

East Oregonian, Pendleton, Oregon.

Oregonian, Portland, Oregon.

Walla Walla Union, Walla Walla, Washington. 
Other Sources

Herr, Henry R. Diary. Typed manuscript of 1862 diary, Mss 1508. Oregon Historical Society.

Inventory of the County Archives of Oregon; No. 30 Umatilla

County (Pendleton). The Oregon Historical Records Survey,

Work Projects Administration, January 1942.

Oregon Pioneer Association, Transactions, 1877-1893.

Umatilla County Commissioners' Journals, County Courthouse, Pendleton, Oregon.

Umatilla County Roads and Field Notes, Roadmaster's Office, Pendleton, Oregon. 